\title{
AGE AND GEOCHEMICAL CHARACTER OF GRANITE AND SYENITE PLUTONS IN THE GRENVILLE PROVINCE OF SOUTHEASTERN ONTARIO; INSIGHTS INTO MAGMATISM DURING THE OTTAWAN OROGENY AND EVIDENCE OF THE FRONTENAC INTRUSIVE SUITE IN THE SHARBOT LAKE DOMAIN
}

\author{
By \\ Jamie Alistair Cutts
}

A thesis submitted to the Faculty of Science

in partial fulfillment of the requirements for the degree of Master of Science

Department of Earth Sciences

Carleton University Ottawa, Ontario January, 2014 


\section{ABSTRACT}

Seven plutons in the Composite Arc Belt and Frontenac terrane of the Grenville Province are herein determined to be part of the Kensington-Skootamatta intrusive suite. The monzonite-syenite plutons and granite-monzogranite plutons have crystallization ages of ca. 1086-1072 Ma and ca 1077-1067 Ma, respectively. In general, the plutons are shoshonitic, metaluminous to weakly peraluminous, and alkalic to calc-alkalic. The plutons have conflicting trace element geochemical signatures that suggest a within-plate tectonic setting with a weak remnant suprasubduction zone signature and a depleted mantle isotopic signature of $\varepsilon N d 2-5$.This geochemistry points to derivation of these melts through fractionation of an alkaline basalt and, or, partial melting of quartzofeldspathic crust. Melt generation was perhaps initiated by crustal delamination, and further heated though insulation by overthickened crust and the Midcontinent Rift magmatic system. Two other plutons that were studied have ca. 1180-1160 Ma crystallization ages and geochemical characteristics similar to the Frontenac intrusive suite. 


\section{ACKNOWLEDGMENTS}

I would first and foremost like to thank my co-supervisors Drs. Sharon Carr and Michael Easton for creating and overseeing this project, and for their constant support and guidance. Thank you to Dr. Easton for taking further time out of his busy schedule to drive from Sudbury for field work and for thesis meetings here in Ottawa. My committee advisory members Drs. Tony Fowler and John Blenkinsop also provided their expertise with granitoid geochemistry and isotope systems. Dr. Blenkinsop's expertise with mass spectrometry and with Selena's quirks and intricacies was invaluable. This project would not have been possible without funding from a National Science and Engineering Research Council (NSERC) Discovery Grant to Dr. Sharon Carr, Carleton University, funding from the Ontario Geological Survey (OGS) including provision of thinsections and whole-rock geochemistry analysis at Geoscience Laboratories, support from Dr. John Blenkinsop's research funds, and support from the Geological Survey of Canada geochronology laboratory.

Thank you to Mike Jackson and Peter Jones for help in the rockpreparation lab and for imaging zircon grains and to Rhea Mitchell for her advice, expertise and patience in conducting the isotope analyses and during the long months of trial-and-error in the U-Pb geochronology lab. Thanks to Vicki McNicoll and Linda Cataldo for support and expertise in rejuvenating the U-Pb lab at Carleton University. The last push of geochronology data acquisition would also not have been possible without the help of the Lianna Vice and Peter Oliver. 
Thanks to Ken Ford from the Geological Survey of Canada for providing sample powders from the Barber's Lake pluton.

Finally, I thank my friends and family for their never-ending support; especially while I attempted to juggle school and training, the Grenville Supergroup, and to Andy Moor and Matt Darey for keeping the beat and driving me forward. 


\section{TABLE OF CONTENTS}

ABSTRACT

ACKNOWLEDGEMENTS iii

TABLE OF CONTENTS V V V V

LIST OF TABLES I ix

LIST OF FIGURES $\quad$ X

LIST OF APPENDICES X xii

CHAPTER 1 - INTRODUCTION

1.1Previous Work 3

$\begin{array}{ll}\text { 1.2 Purpose } & 5\end{array}$

1.3 Sampling Rational $\quad 5$

1.4Preliminary Results $\quad 6$

CHAPTER 2 - GEOLOGICAL SETTING 13

2.1Regional Geological Setting of the Ontario Grenville 13 Province

2.2Regional Setting and Plutonism at ca. 1190-1140 Ma 15

2.3Regional Setting and Plutonism at ca. 1090-1060 Ma 16

2.4 The Kensington-Skootamatta suite 16

2.5Local Geological and Structural Setting of the Study 18 Areas

2.5.1 Structural Setting of the Study Areas 
2.5.2 Grimsthorpe domain - Skootamatta pluton 20

2.5.3 Sharbot Lake domain - Cranberry Lake pluton $\quad 20$

2.5.4 Sharbot Lake domain - Elphin and Barbers Lake $\quad 21$ plutons

2.5.5 Sharbot Lake domain - McLean and Leggat Lake Plutons

2.5.6 The Frontenac terrane - Westport area plutons

CHAPTER 3 - GEOCHEMISTRY 25

3.1 Geochemistry Methods $\quad 25$

$\begin{array}{ll}\text { 3.2Results } & 27\end{array}$

$\begin{array}{ll}\text { 3.2.1 Syenite-monzonite suite } & 27\end{array}$

3.2.2 Granite-monzogranite suite $\quad 30$

3.2.3 The Cranberry Lake pluton 33

3.2.4 The Elphin pluton $\quad 34$

3.3 Summary of Geochemistry Results 36

CHAPTER 4 - GEOCHRONOLOGY 51

4.1 Geochronology Methods $\quad 51$

4.2 Age interpretations 53

4.3 Results $\quad 54$

4.3.1 Skootamatta pluton - 92RME-0402 54

4.2.2 Wolfe Lake pluton - JC-050

$\begin{array}{ll}\text { 4.2.3 Rideau Lake pluton - JC-070 } & 58\end{array}$ 
4.2.4 Leggat Lake pluton - JC-063

4.2.5 Elphin pluton - JC-059 61

4.2.6 The Cranberry Lake pluton - JC-066 63

4.4 Summary of Geochronology Results 64

$\begin{array}{ll}\text { CHAPTER } 5 \text { - DISCUSSION } & 76\end{array}$

5.1 The Kensington-Skootamatta suite $\quad 76$

5.1.1 Comparison of syenite-monzonite and granite- $\quad 76$ monzogranite suites

5.2 Tectonic classification and melt origin of the Kensington- $\quad 78$

Skootamatta suite

$\begin{array}{ll}\text { 5.2.1 Tectonic classification } & 78\end{array}$

$\begin{array}{ll}\text { 5.2.2 Melt origin - Geochemistry } & 79\end{array}$

5.2.3 Geochemistry and geochronology interpretations 82 summary

5.3 Tectonic model

83

5.3.1 Apparent absence of Kensington-Skootamatta

85 plutonism in the Mazinaw terrane?

5.4 The Cranberry Lake pluton 86

5.4.1 Implications for the Robertson Lake shear zone 86

$\begin{array}{ll}\text { 5.5 The Elphin pluton } & 87\end{array}$

5.6 Implications for the Frontenac intrusive suite 88

CHAPTER 6 - CONCLUSIONS 92

$\begin{array}{ll}\text { 6.1 First order conclusions } & 92\end{array}$ 


\section{LIST OF TABLES}

Table 1.1: General stratigraphy, age, metamorphic character and tectonic setting of the Grimsthorpe and Sharbot Lake domains and the Frontenac terrane.

Table 1.2: Previous geochronology data for ca. 1090-1060 Ma plutons.

Table 3.1: Representative major and trace element whole-rock geochemistry

Table 3.2: $\mathrm{Sm}-\mathrm{Nd}$ and $\mathrm{Rb}-\mathrm{Sr}$ isotope geochemistry analytical data

Table 4.1: Table 4.1: U-Pb zircon ID-TIMS analytical data

Table 4.2: U-Pb zircon geochronology rejected data from Skootamatta pluton lab tests

Table 4.3: U-Pb zircon geochronology results summary

Table 5.1: U-Pb zircon ages for Kensington-Skootamatta suite plutons of Ontario 


\section{LIST OF FIGURES}

Figure 1.1 - The eastern Grenville Province in Ontario, the major subdivisions of the Composite Arc Belt and Frontenac terrane and the extent of the ca. 1090-1060 Ma KensingtonSkootamatta Suite. Figure caption is on page 10.

Figure 1.2 - Detailed geology of the plutons from the syenite-monzonite Suite

Figure 1.3 - Detailed geology of the plutons from the granitemonzogranite suite

Figure 2.1 - Schematic cross-section of the Grenville Orogen at ca. $1060 \mathrm{Ma}$.

Figure 3.1 - Representative sample photographs and photomicrographs for the syenite-monzonite suite plutons.

Figure 3.2 - Whole-rock major element geochemistry rock-classification diagrams. Figure caption is on page 45.

Figure 3.3 - Whole-rock geochemistry normalised multi-element diagrams. Figure caption is on page 47

Figure 3.4 - Whole-rock trace-element geochemistry tectonic discrimination diagrams.

Figure $3.5-\varepsilon N d$ vs. initial Sr isotope diagram

Figure 3.6 - Representative sample photographs and photomicrographs of the granite-monzogranite suite plutons.

Figure 4.1 - Representative zircon images

Figure 4.2 - Representative zircon SEM images

Figure 4.3 - U-Pb zircon ID-TIMS concordia diagrams

Figure 5.1 - Pluton emplacement summary diagram 


\section{LIST OF APPENDICES}

Appendix A - MRD 311: CD-ROM

Miscellaneous Release-Data 311: Release blurb

MRD311_release blurb.doc

Miscellaneous Release-Data 311: Readme file

MRD311_readme.doc: Contains a list and description of all files included in MRD311 appendix. 


\section{CHAPTER 1 - INTRODUCTION}

During the ca. 1090-980 Ma Grenville Orogeny, the ca. 1090-1060 Ma Kensington-Skootamatta ultrapotassic, alkaline intrusive suite was emplaced throughout the constituent terranes and domains of the Composite Arc Belt $(\mathrm{CAB})$ and the Frontenac-Adirondack Belt (FAB; figure 1.1a, b). Circa 1090-1060, much of the Composite Arc Belt and Frontenac-Adirondack Belt were at mid- to upper-crustal levels and remained sheltered from the penetrative compressional deformation and metamorphism experienced by rocks near the Laurentian margin and at deeper crustal levels (e.g., Mazinaw terrane; cf. Rivers 2012). Rather, the terranes of the Composite Arc Belt and Frontenac-Adirondack Belt experienced late-stage extension through crustal-scale normal faults (Carr et al. 2000).

Corriveau et al. (1990) and Corriveau (1990) first introduced the term Kensington suite for 10 ultrapotassic, undeformed plutons in the Grenville Province in the Mont-Laurier region of Québec (figure 1.1b). Easton (1992) subsequently introduced the Skootamatta suite for plutons of this composition and general age in the Grenville Province of Ontario. The two suites together have since been referred to as the Kensington-Skootamatta suite.

The regionally extensive ca. 1090-1060 Ma Kensington-Skootamatta suite comprises undeformed and unmetamorphosed alkalic, shoshonitic to ultrapotassic syenite to monzonite plutons. The roughly 30 sub-circular intrusive bodies are aligned along a $400 \mathrm{~km}$ northeast-southwest trending, structure 
parallel belt stretching in the northeast from Mont-Laurier in Quebec to Bancroft in the southwest. They are associated with aeromagnetic highs (figure 1.1b; Corriveau et al. 1990; Easton 1992). Easton (2008) suggested that the Kensington-Skootamatta suite may in fact be composed of two different suites of different ages and compositions; a ca. 1080 syenite-monzonite suite and a younger ca. 1070 Ma granite-monzogranite suite. Alternatively, the younger granite-monzogranite suite may be associated with the ca. 1070-1060 Catchacoma suite (Easton and Kamo 2011).

Nine plutons were selected for field, petrographic, geochemistry, isotope geochemistry and geochronology studies based on a number of factors, including: representation from a variety of lithotectonic domains, terranes and crustal levels; ease of accessibility; inclusion of a range of rock-types; and to infill and complement existing data sets for the suite based on limited previous work on other plutons. The plutons that were selected include the Skootamatta and Westport area plutons (Wolfe Lake, Foley Mountain, and Rideau Lake) which are believed to be part of the syenite-monzonite suite (figure 1.2), and the Elphin, Barber's Lake, McLean, Leggat Lake and Cranberry Lake plutons, which are believed to be part of the granite-monzogranite suite (figure 1.3). To avoid confusion, the three plutons in Westport, Ontario are referred to as 'the Westport area plutons' and the former 'Westport pluton' will be referred to as 'the Foley Mountain pluton'. The plutons in this study are located within the Grimsthorpe domain, Sharbot Lake domain, and Frontenac terrane (figure 1.1a,b). 
The majority of the Kensington-Skootamatta plutons have a roughly round map pattern; in part, suggesting that they are undeformed. The Cranberry Lake pluton is of particular interest because firstly, it lies adjacent to the Robertson Lake shear zone (RLSZ); a major tectonic boundary between the Mazinaw terrane and Sharbot Lake domain, and secondly, the pluton has a complex map pattern that cross-cuts regional folds, thought to have formed prior to circa 1180 Ma. As a result, Easton (2001a) suggested that it may be a syn-tectonic intrusion during a stage of displacement along the Robertson Lake shear zone.

\subsection{Previous work}

The major element geochemistry of the Kensington-Skootamatta suite was characterised by Corriveau et al. (1990) as having low to moderate silica contents, $\mathrm{TiO}_{2}>0.8 \mathrm{wt} \%$, and $\mathrm{P}_{2} \mathrm{O}_{5}>0.21 \mathrm{wt} \%$. Note that Corriveau's research was concentrated on the syenites of the Kensington-Skootamatta suite and there has been limited previous work on the granitoids. There have been few subsequent geochemical studies on the Kensington-Skootamatta suite. Preliminary sampling and geochemical analysis of the Barbers Lake, McLean, Leggat Lake and Elphin plutons was carried out by Davidson and van Breemen (2000b). Similarly, Easton (2001a) studied the Cranberry Lake pluton. More extensive sampling and analysis for major, and trace elements (excluding the rare earth elements (REEs)) of the Skootamatta syenite was carried out by Easton and Ford (1994).

A variety of tectonic settings and source region scenarios have been proposed for Kensington-Skootamatta plutons based on major, trace element, 
radiogenic isotope $(\mathrm{Sr}, \mathrm{Sm}-\mathrm{Nd})$ and stable isotope $(\mathrm{O})$ geochemistry. Corriveau (1990) and Corriveau et al. (1990) suggested a subduction zone model, whereas others have suggested an anorogenic, within-plate tectonic setting (Corrigan and Hanmer 1997).

Stable isotope $(\mathrm{O})$ and radiogenic isotope $(\mathrm{Sr}, \mathrm{Nd})$ geochemistry studies were conducted on the Westport area, Elphin and Barber's Lake plutons, and revealed $\Delta \mathrm{O}^{18}$ values of 8.0-11.5, $\varepsilon N d$ values of 2.7-3.4 and $\varepsilon S r$ values of 7.638.9 (Marcantonio et al. 1990; Shieh 1985; Wu and Kerrich 1986). These isotopic values were interpreted as a remnant signature of an already enriched mafic igneous source, with some contamination from the surrounding marble and metasedimentary rocks.

Previous published geochronology work on the plutons of this study include crystallisation ages for the Westport (Foley Mountain) pluton of $1076 \pm 2$ (Corriveau et al. 1990; sometimes reported as $1077 \pm 4$ Ma based on Marcantonio et al. 1988), and crystallisation ages for the Barbers Lake and McLean plutons of $1066^{+3 /-4}$ Ma and $1070 \pm 3 \mathrm{Ma}$, respectively (Davidson and van Breemen 2000b). There are unpublished geochronology data for the Skootamatta pluton at ca. $1083 \mathrm{Ma}$ (Carr and Easton 1995, unpublished data).See table 1.2 for geochronology data for all ca. 1090-1060 Ma plutons in the map area. 


\subsection{Purpose}

Several questions will be addressed herein based on a synthesis of previous work integrated with new petrology, geochemistry and geochronology data from plutons of the Kensington-Skootamatta suite: First-order questions are (i) what are the major and trace element geochemical signatures and isotopic geochemical character of the plutons selected for study?; (ii) what is the crystallization age of the Skootamatta, Rideau Lake, Wolfe Lake, Elphin, Leggat Lake and Cranberry Lake plutons? Second-order questions are (iii) based on the conclusions from (i) and (ii), are the granites and syenites part of the same igneous suite, or do they represent more than one distinct suite with different tectonic associations? (iv) if the rocks are one co-genetic suite, did they originate from a single source or multiple sources? (v) are there terrane specific sources that could account for the formation of the granite versus syenite plutons and/or local differences between intrusions? (vi) what melt sources or tectonic settings could account for the geochemistry data and does this agree with current tectonic models for Grenville orogenesis? (vii) and, why is the Mazinaw terrane apparently devoid of plutons of the Kensington-Skootamatta suite?

\subsection{Sampling Rational}

In total, 79 samples were collected for petrography and geochemical analysis. Five of these locales were also sampled for U-Pb zircon geochronology studies. Sampling of the plutons was based on obtaining different mineralogical and textural phases of each of the plutons, and where possible, along transects across the plutons from core to rim. Sampling was limited due to difficulty in 
accessing private property; hence there was a focus on collecting from road cut exposures and in the case of the Barbers Lake pluton, using previously collected sample powders from Ken Ford.

\subsection{Preliminary Results}

Preliminary results related to this study have been presented in Ontario Geological Survey Open File Reports 6270 and 6280, and at the Geological Association of Canada—Mineralogical Association of Canada annual meeting 2013 (Cutts et al. 2011, 2012, 2013). Raw geochemistry data, isotope geochemistry and U-Pb geochronology sample preparation and chemistry procedures, outcrop photographs, hand sample photographs, photomicrographs, and scanning electron microscope cathodoluminescence images have been published in Ontario Geological Survey Miscellaneous Release-MRD311 (appendix A). 
Table 1.1 - General stratigraphy, age, metamorphic character and tectonic setting of the Grimsthorpe,

Sharbot Lake and Frontenac terranes.

\begin{tabular}{|c|c|c|c|c|}
\hline Terrain/ Domain & Stratigraphy & Age & Metamorphism & $\begin{array}{l}\text { Basement } \\
\text { Assemblage } \\
\text { Tectonic } \\
\text { Setting }\end{array}$ \\
\hline \multirow[t]{3}{*}{$\begin{array}{l}\text { Grimsthorpe } \\
\text { domain }^{1,2}\end{array}$} & $\begin{array}{l}\text { Kensington-Skootamatta } \\
\text { syenite-monzonite plutons }\end{array}$ & са. $1088 \mathrm{Ma}$ & None & \\
\hline & $\begin{array}{l}\text { Mafic and felsic plutonic rocks } \\
\text { preserving primary features }\end{array}$ & ca. $1267 \mathrm{Ma}$ & $\begin{array}{l}<1267 \mathrm{Ma} \text { upper } \\
\text { greenschist to mid- } \\
\text { amphibolite facies }\end{array}$ & \\
\hline & $\begin{array}{l}\text { Deformed tholeiitic intrusive, } \\
\text { volcanic and volcaniclastic } \\
\text { rocks }\end{array}$ & $>1267 \mathrm{Ma}$ & & Primitive Arc \\
\hline \multirow[t]{3}{*}{$\begin{array}{l}\text { Sharbot Lake } \\
\text { domain }^{3,4}\end{array}$} & $\begin{array}{l}\text { Kensington-Skootamatta } \\
\text { granite-monzogranite plutons }\end{array}$ & ca. $1067 \mathrm{Ma}$ & None & \\
\hline & $\begin{array}{l}\text { Deformed gabbro and tonalite } \\
\text { plutons }\end{array}$ & ca. $1168 \mathrm{Ma}$ & $\begin{array}{l}\text { ca. } 1160 \text { Ma mid- } \\
\text { amphibolite to } \\
\text { granulite facies }\end{array}$ & \\
\hline & $\begin{array}{l}\text { Deformed marble, tholeiitic } \\
\text { metavolcanic, and siliciclastic } \\
\text { metasedimentary rocks }\end{array}$ & $>1224 \mathrm{Ma}$ & & Rifted arc \\
\hline \multirow[t]{3}{*}{$\begin{array}{l}\text { Frontenac } \\
\text { terrane }\end{array}$} & $\begin{array}{l}\text { Kensington-Skootamatta } \\
\text { syenite-monzonite plutons }\end{array}$ & ca. $1076 \mathrm{Ma}$ & None & \\
\hline & $\begin{array}{l}\text { Syn-deformational monzonite to } \\
\text { granite plutons }\end{array}$ & ca. $1190-1160 \mathrm{Ma}$ & $\begin{array}{l}\text { ca. } 1160 \text { granulite } \\
\text { facies }\end{array}$ & \\
\hline & $\begin{array}{l}\text { Quartzofeldspathic gneiss, } \\
\text { monzonite to granite } \\
\text { orthogneiss, quartzite and } \\
\text { marble }\end{array}$ & $\begin{array}{l}>1190 \mathrm{Ma} \text { (detrital } \\
\text { zircon age from } \\
\text { quartzites of } 1306 \\
\text { and } 1400 \mathrm{Ma} \text { ) }\end{array}$ & & $\begin{array}{l}\text { Platform/ } \\
\text { ocean basin }\end{array}$ \\
\hline
\end{tabular}

${ }^{1}$ Easton and Ford 1994; ${ }^{2}$ Carr and Easton, unpublished age; ${ }^{3}$ Corfu and Easton 1997;

${ }^{4}$ Davidson and van Breemen 2000b; ${ }^{5}$ Davidson and van Breemen 2000a; ${ }^{6}$ Corriveau et al. 1990 
Table 1.2: Published zircon geochronology data on ca. 1090-1060 Ma felsic plutons

\begin{tabular}{llll} 
Pluton & Rock Type & Age (Ma) & Reference \\
\hline Calabogie & syenite & $1088 \pm 2$ & Corriveau et al. (1990) \\
Gawley Creek & syenite & 1088 & Lumbers et al. (1990) unpublished data \\
Loon Lake & monzonite & $1090 \pm 2$ & Corriveau et al. (1990) \\
Mount Moriah & syenite & 1088 & Lumbers et al. (1990) unpublished data \\
Skootamatta & syenite,monzonite & 1083 & Carr and Easton (2005) unpublished data \\
Umfraville & syenite & 1088 & Lumbers et al. (1990) unpublished data \\
Belmont Lake & granite & $1088+3 /-2$ & Davis and Bartlett (1988) \\
Kensington & syenite & $1083 \pm 2$ & Corriveau et al. (1990) \\
Lac Rouge & syenite & $1081 \pm 2$ & Corriveau et al. (1990) \\
Loranger & syenite & $1076+3 /-1$ & Corriveau et al. (1990) \\
& & $1077 \pm 4$ or & Marcantonio et al. 1988; Corriveau et al. \\
Westport (Foley Mountain) & monzonite & $1076 \pm 2$ & (1990) \\
Barber's Lake & granite, monzogranite & $1066+7 /-4$ & Davidson and van Breemen 2000b \\
Cavendish Township & monzogranite & $1067 \pm 4$ & Easton and Kamo (2008) \\
McLean & monzogranite & $1070 \pm 3$ & Davidson and van Breemen 2000b \\
\hline
\end{tabular}



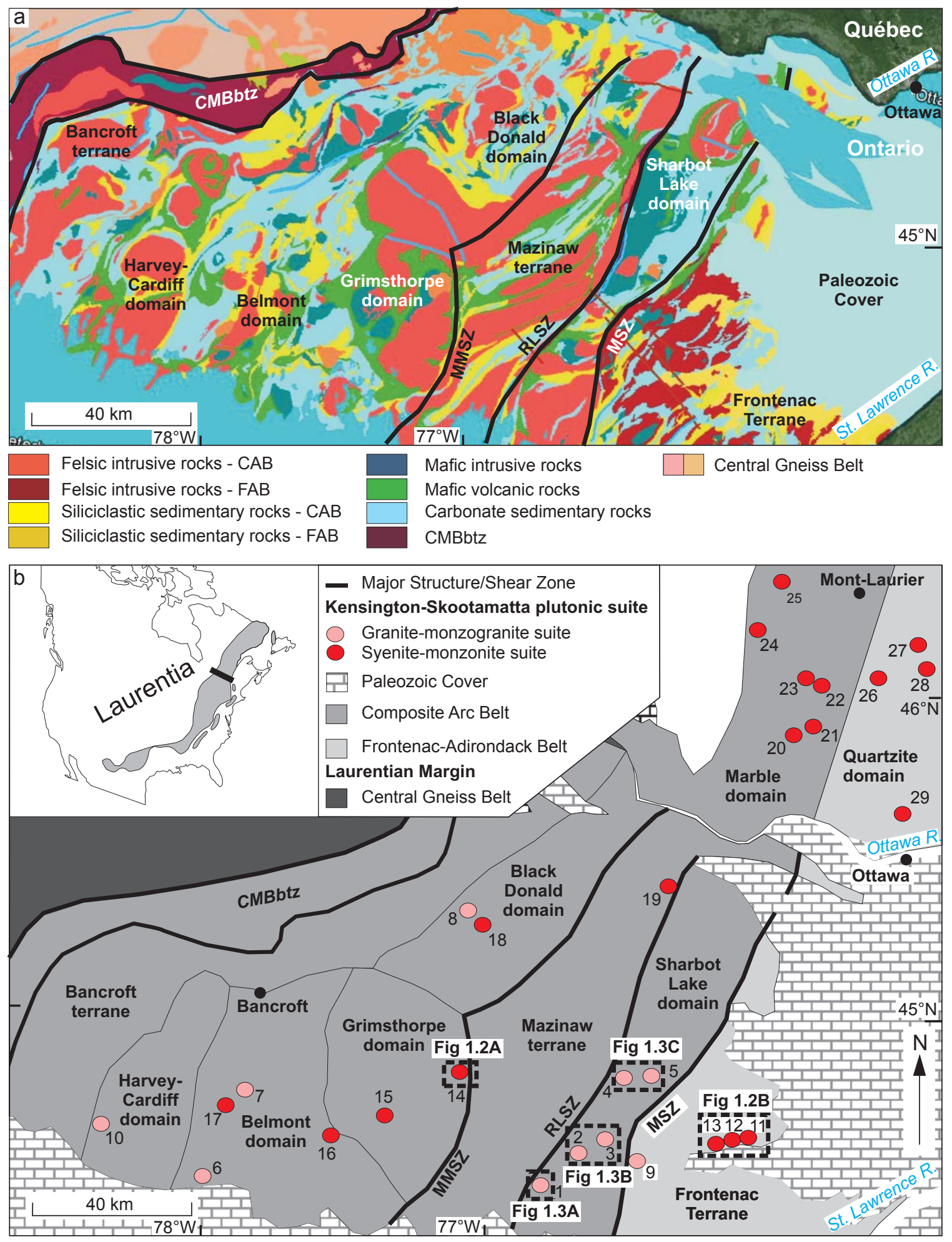
Figure 1.1: a) 1:100 000 scale geological map of the Grenville Province of eastern Ontario showing approximate domain and terrane locations with major shear zones. Map is modified from Ontario Geological Survey (2011) b) Schematic figure of the Grenville Province of eastern Ontario and southeastern Québec showing approximate domain and terrane locations, major shear zones and the extent of the ca. 1090-1060 Ma Kensington-Skootamatta ultrapotassic intrusive suite (modified after Carr et al. 2000; Corriveau and van Breemen 2000) with pluton locations from Corriveau and van Breemen (2000) and Easton (2008). Inset delineates the extent of the Grenville Province in North America, and the black rectangle indicates the location of figures $1.1 \mathrm{a}$, and $\mathrm{b}$ and the cross-section profile in figure 2.1. Locations of figures $1.2 a$ to $1.3 c$ delineated. See table 1.1 for details of the individual domains shown in the figure. Granitemonzogranite plutons are numbered 1-10 and syenite-monzonite plutons are numbered 11-29. 1-Cranberry Lake; 2-McLean; 3-Leggat Lake; 4-Elphin; 5Barbers Lake; 6- Belmont Lake; 7-Coe Hill; 8- Burns Lake; 9 - Bob's Lake, 10Catchacoma; 11-Rideau Lake; 12-Foley Mountain; 13-Wolfe Lake; 14Skootamatta; 15-Mount Moriah; 16-Gawley Creek; 17-Loon Lake; 18-Mount St. Patrick; 19-Calabogie; 20-Gracefield; 21-Cameron; 22-Satellite; 23-Kensington; 24-Baskatong; 25-Piscatosine; 26-Lac Rouge; 27-Sainte Véronique; 28Loranger; 29-unnamed. CMBbtz-Central Metasedimentary Belt boundary thrust zone; MMSZ-Mooroton Shear Zone; MSZ-Maberly Shear Zone; RLF-Rideau Lake Fault; RLSZ-Robertson Lake Shear Zone. 


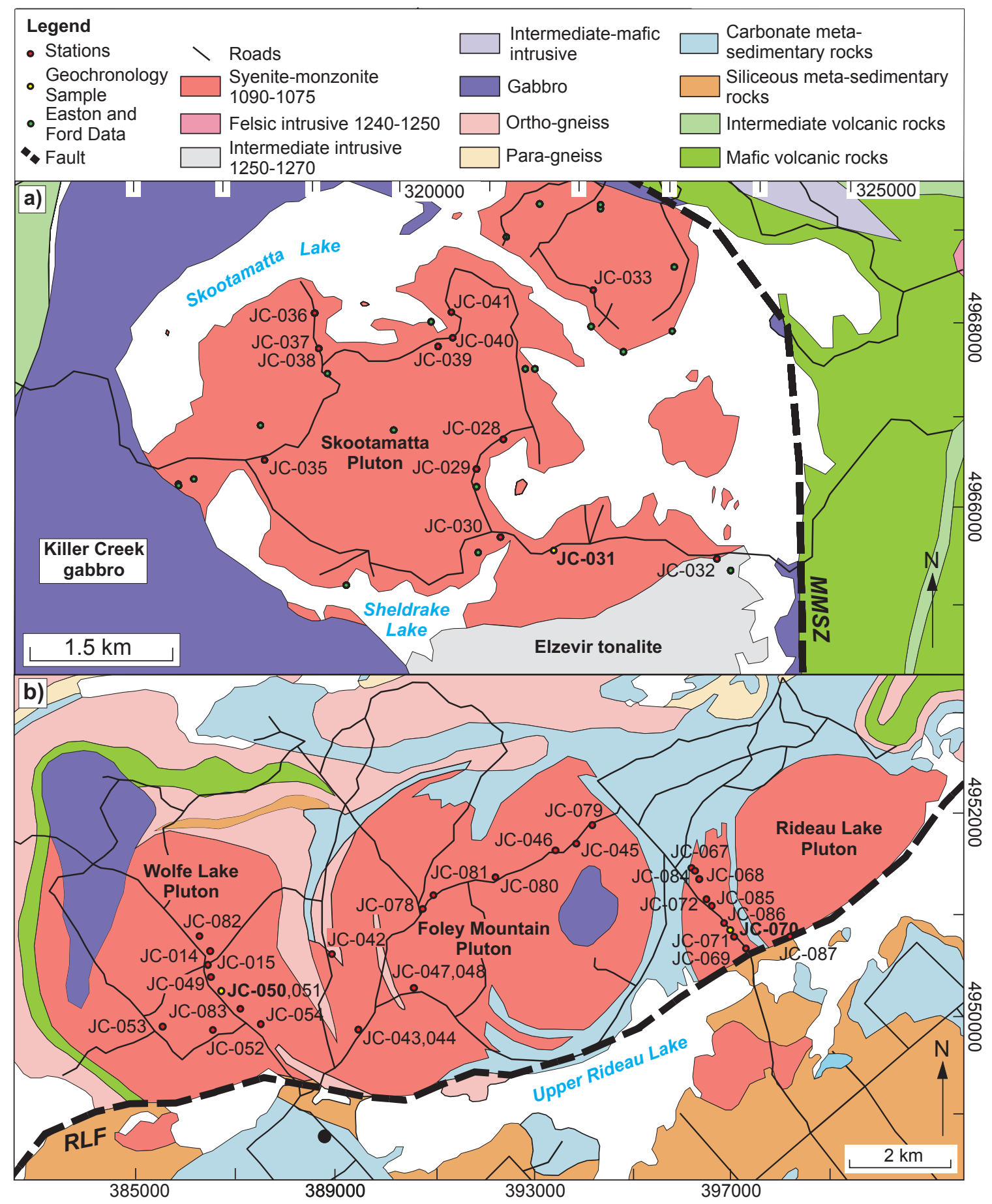

Figure 1.2: Detailed 1:50 000 scale geological maps of syenite-monzonite plutons from this study showing the geochemistry and geochronology sample locations from this study and sample locations from Easton and Ford (1994). a) The Skootamatta pluton and the Grimsthorpe domain (modified from Easton 2001d); b) The Westport Area plutons and the western Frontenac terrane (modified from Hewitt 1964). Locations of these maps are shown on figure 1.1b. MMSZ Mooroton shear zone; RLF - Rideau Lake Fault 


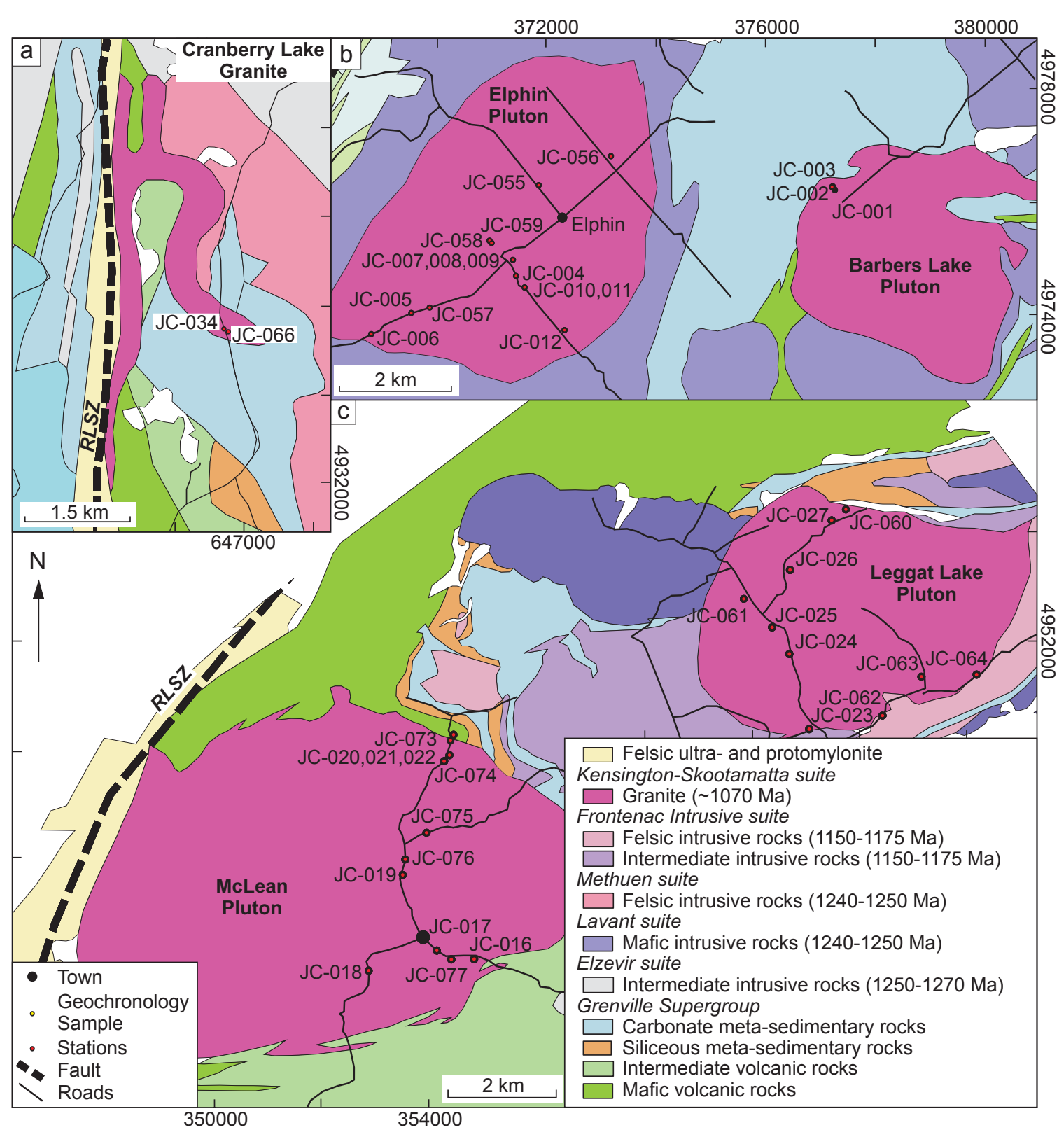

Figure 1.3: Detailed 1:50 000 scale geological maps of granite-monzogranite plutons from this study showing the geochemistry and geochronology sample locations. a) the Cranberry Lake Granite and the southwestern Sharbot Lake domain (modified from Easton 2001b); b) Elphin and Barbers Lake granite and the central Sharbot Lake domain (modified from Easton 2001b).; c) McLean and Leggat Lake and the southeastern Sharbot Lake domain (modified from Easton 2001c). Locations of these maps are shown on figure 1.1b. RLSZ - Robertson Lake shear zone. 


\section{CHAPTER 2 - GEOLOGICAL SETTING}

\subsection{Regional Geological Setting of the Ontario Grenville Province}

The Grenville Province was constructed in multiple stages between ca. 1300-980 Ma. The predominant orogenic event, the Ottawan orogeny, resulted in construction of the main architecture of the large, hot, Himalayan-style (Beaumont et al. 2006) orogeny by ca. 1060 Ma. There were protracted orogenesis and extensional events as young as ca. $980 \mathrm{Ma}$ (e.g. Rigolet orogenic phase). Significant tracts of rock exposed in southeastern Ontario preserve evidence of the ca. 1240 Ma Elzevirian Orogeny and the ca. 1190-1140 Ma Shawinigan orogeny, which were overprinted during the Ottawan orogeny. The present day erosional level in Ontario exposes some of the rocks that were in the core zone or infrastructure during Grenville orogenesis (e.g. Laurentia and near the pre-Grenvillian Laurentian margin, Mazinaw terrane) as well as tracts of rocks that were at upper crustal levels or in the superstructure (c.f. orogenic lid: Rivers 2012) during Grenville orogenesis (e.g. parts of the Composite Arc Belt $(\mathrm{CAB})$ and the Frontenac-Adirondack Belt (FAB); figures 1.1, 2.1: Carr et al. 2000; Culshaw et al. 2006).

This study focuses on post-tectonic plutons that are located in the Grimsthorpe and Sharbot Lake domains of the Composite Arc Belt, and the Frontenac terrane of the Frontenac-Adirondack Belt (figures 1.1, 2.1). See table 1.1 for further details of the geology of the constituent terranes. The volcanic arcs that comprise the Composite Arc Belt formed outboard of Laurentia at ca. 1280- 
$1270 \mathrm{Ma}$ and their formation was approximately coeval with that of related sedimentary basins. These arcs were amalgamated between 1245-1230 Ma, during the Elzevirian orogeny, to form the Composite Arc Belt (Carr et al. 2000). There may be a north-south difference in the timing of Elzevirian magmatism. Elzevirian plutonic complexes in the northern-Composite Arc Belt are ca. 12401230 (Pehrsson et al. 1996; Easton 1992) whereas, those in the southernComposite Arc Belt have ages of ca. 1270-1250 Ma (Corfu and Easton 1997; Easton 1992). The Frontenac- Adirondack belt, although younger than the Composite Arc belt, is similar in that there are a number of components that are interpreted to have formed in a regime outboard of Laurentia at ca. $1300 \mathrm{Ma}$ (figure 1.1; Carr et al. 2000).

An alternate view on Elzevir orogenesis is based on geochronology and geochemistry from the Central Gneiss Belt and the Adirondack highlands and lowlands. This model states that the Elzevirian Orogeny was a ca. 1350-1185 Ma protracted event that involved continental-arc Andean-type magmatism on the Laurentian margin (c.f. Hanmer et al. 2000; McLelland et al. 1996). These arcs were subsequently rifted from the margin and re-accreted during a ca. $1200 \mathrm{Ma}$ continent-continent collision (Hanmer et al. 2000). For the purposes of this thesis, the Carr et al. (2000) model will be used.

The Composite Arc Belt and Frontenac-Adirondack Belt were subsequently amalgamated to each other by ca. 1190-1140 Ma during the Shawinigan Orogeny and stitched together by the Frontenac intrusive suite (Carr et al. 2000; Corfu and Easton 1997). According to the model proposed by Carr et al. (2000), 
following this amalgamation, these combined terranes were accreted to, and in some cases obducted onto the Laurentian margin. The accreted terranes together with the Laurentian margin underwent Himalayan-style orogenesis at ca. 1090-1020 Ma during the Ottawan phase of the Grenville Orogeny (Carr et al. 2000; Rivers 2008; Rivers 2012). Circa 1090-1020 Ma Ottawan orogenesis culminated at ca. $1060 \mathrm{Ma}$ and evidence is preserved mainly in rocks, now exposed, that were in the infrastructure of the Grenville Orogen (e.g. Laurentian margin, Central Gneiss Belt and Central Metasedimentary Belt boundary thrust zone (CMBbtz: figure 1.1)). In contrast, the superstructure (eastern Composite Arc Belt and parts of the Frontenac-Adirondack Belt) remained relatively unaffected by deformation and metamorphism (Culshaw et al. 1997; Rivers 2008; Rivers 2012).

\subsection{Regional setting and plutonism at ca. 1190-1140 Ma}

The ca. 1190-1140 Ma Shawinigan Orogeny involved the amalgamation of the Composite Arc Belt and Frontenac-Adirondack Belt by ca. 1160 (Carr et al. 2000; Corfu and Easton 1997; Hanmer and McEachern 1992; McEachern and van Breemen 1993). There was coincident extensional magmatism resulting in the emplacement of ca. 1180-1160 Ma 'A-type' monzonites, granites and syenites of the Frontenac intrusive suite, anorthosite-mangerite-charnockite-granite complexes, and associated mafic to alkali intrusive rocks in both the Sharbot Lake domain of the Composite Arc Belt and in the Frontenac terrane. Some of the Frontenac suite plutons span the boundary zone between these two domains, thus acting as stitching plutons that post-dated and constrain the age of 
the end of this tectonic event (Corfu and Easton 1997; Carr et al. 2000; Davidson and van Breemen 200a)

\subsection{Regional setting and plutonism at ca. 1090-1060 Ma}

The Ottawan orogeny involved ca. 1090-1030 Ma Himalayan-style orogenesis in a continent-continent collision with crustal thickening and shortening. From ca. 1090-1060 Ma most of the deformation and metamorphism was focussed on the voluminous infrastructure at deep- to mid-crustal levels, along the Grenville Front Tectonic Zone (GFTZ) and the Central Metasedimentary Belt boundary thrust zone (CMBbtz; Carr et al. 2000). Meanwhile, parts of the Composite Arc Belt and Frontenac terrane were located at shallow crustal levels ( $<12 \mathrm{~km}$ : Busch et al. 1996) and escaped much of the penetrative Ottawan regional deformation and metamorphism (Carr et al. 2000).

The Mazinaw terrane, however, is an exception in that it experienced ca. 10501000 Ma high-grade orogenesis at deep crustal levels ( 20-25 km: Busch et al. 1996; Corfu and Easton 1995). The Kensington-Skootamatta suite was emplaced in the Frontenac-Adirondack Belt and much of the Composite Arc Belt during this time interval (Carr et al. 2000; Rivers 2012).

\subsection{The Kensington-Skootamatta suite}

The Kensington-Skootamatta suite is a syn- to post-tectonic, postmetamorphic intrusive suite that occurs in a linear belt that strikes northeastsouthwest for $400 \mathrm{~km}$ within the Composite Arc Belt and Frontenac terrane (and equivalents in Quebec). The plutons of the Kensington-Skootamatta suite were emplaced at ca. 1090-1060 Ma during the Ottawan-stage of the Grenville 
Orogeny (Carr et al. 2000) and do not occur in the Mazinaw domain. The Calabogie syenite is a possible exception (figure 1.1); however, it is located in an area where the terrane boundaries are not well defined. Granite pegmatite dikes were emplaced into higher metamorphic grade portions of the Composite Arc Belt between 1080 and $1030 \mathrm{Ma}$ (cf. Easton 1986, 1992), for example at ca. $1080 \mathrm{Ma}$ in northern Mazinaw domain (Corfu and Easton 1995). The relationship of these late granite pegmatite dikes to the Kensington-Skootamatta suite is unknown, and is beyond the scope of the thesis.

In general, the plutons are medium- to coarse-grained, unmetamorphosed and undeformed, locally displaying a weak biotite foliation at the margins, and cut across foliatons, folds and regional structures in the country rock. There is lack of evidence for contact aureoles surrounding the plutons. The syenite-monzonite plutons can further be distinguished geophysically by their moderate eU and eTh contents and typically intense aeromagnetic highs, whereas the granitemonzogranite plutons have high $\mathrm{K} / \mathrm{eTh}$ ratios, varied eU and eTh contents, and range in aeromagnetic character from low to moderate values to intense highs (Easton 2008). Associated with the Kensington suite in Quebec is a ca. $1070 \mathrm{Ma}$ minette dyke containing foliated, gneissic and mylonitic fabric (Corriveau and Morin 2000). Previous descriptions of the plutons of the Kensington-Skootamataa suite have characterised them as having a relatively low $\mathrm{SiO}_{2}$ content (45-60 wt\%), $\mathrm{TiO}_{2}>0.8$ and $\mathrm{P}_{2} \mathrm{O}_{5}>0.21$ and being alkalic, shoshonitic to ultra-potassic and metaluminous (Corriveau 1990; Corriveau et al. 1990). However, it is important to note that research of Corriveau et al. (1990) was restricted to the 
syenite-monzonite plutons, and there is limited previous work on the granitemonzogranite plutons.

\subsection{Local Geological and Structural Setting of Study Areas}

Geological maps of the study areas, featuring studied plutons and sample locales, are shown in figures 1.1, 1.2 and 1.3 and a schematic diagram showing the relative crustal levels of the constituent terranes and domains at ca. 1090$1060 \mathrm{Ma}$ is shown in figure 2.1. A summary of the geology, geochronology and geochemical interpretations from previous work on the terranes/domains that host the plutons of interest are summarised in table 1.1, and previous geochronology data from ca. 1090-1060 plutons are shown in table 1.2.

\subsubsection{Structural Setting of the Study Areas}

The Grimsthorpe and Sharbot Lake domains and the Frontenac terrane were in the orogenic superstructure at ca. 1090-1060 Ma, thus did not apparently experience penetrative deformation or metamorphism during this time. The Mazinaw terrane, meanwhile, was in the orogenic infrastructure and was being penetratively deformed and metamorphosed during ca. 1060-980 Ma events (figure 2.1; Carr et al. 2000; Corfu and Easton 1995; Corfu and Easton 1997).

The Grimsthorpe domain is bounded on the east by the Mooroton shear zone (MMSZ), an east dipping mylonite zone interpreted to have thrust motion that is older than $1030 \mathrm{Ma}$ (figures 1.1, 1.2a and 2.1: Cureton et al. 1997). The Mooroton shear zone separates the Grimsthorpe domain from the Mazinaw terrane (figures 1.1, 1.2). The crustal level of the Grimsthorpe domain at ca. 
$1090-1060 \mathrm{Ma}$ is uncertain as there is a lack of thermochronology data or other relevant textural information, however, since the Grimsthorpe domain has apparently escaped deformation and metamorphism during the Ottawan orogeny then it was likely at a mid- to upper crustal level at that time $(<15-12 \mathrm{~km}$ : figure 2.1; Rivers 2008; Rivers 2012).

The Sharbot Lake domain is bounded on the west by the Robertson Lake shear zone (RLSZ) and on the east by the Maberly shear zone (MSZ). These shear zones separate the Sharbot Lake domain from the Mazinaw terrane and Frontenac terranes, respectively (figures 1.1, 1.2, 1.3, and 2.1). At ca. 1090-1060 Ma, the Sharbot Lake domain dipped to the east and ranged from shallow $(\sim 12$ $\mathrm{km})$ to mid ( $20 \mathrm{~km})$ crustal depths based on ${ }^{40} \mathrm{Ar} /{ }^{39} \mathrm{Ar}$ thermochronology (Cosca et al. 1992; Busch and van der Pluijm 1995; Busch et al. 1996).

The Frontenac terrane was at a relatively high crustal-level $(<8 \mathrm{~km})$ by ca. $1160 \mathrm{Ma}$, as inferred by granophyric textures, little to no contact aureoles and miarolitic cavities in the ca. 1160 Ma Tichborne granite (Davidson 2001). This is further supported by ${ }^{40} \mathrm{Ar} /{ }^{39} \mathrm{Ar}$ hornblende cooling ages within Frontenac terrane ranging from ca 1125 to $1100 \mathrm{Ma}$ (Cosca et al. 1992; Davidson 2011; Rivers 2012). Furthermore, there has been little no deformation or metamorphism younger than ca. 1180-1140 Ma.

At ca. 1090-1060 Ma, the Mazinaw terrane was at a mid-crustal level ( 25 km: Rivers 2012; Busch et al. 1996). Extensional events beginning ca. 1030 Ma, led to normal faulting and displacement along crustal scale faults such as the 
Mooroton shear zone and Robertson Lake shear zone. These shear zones juxtaposed the Mazinaw terrane against the Grimsthorpe and Sharbot Lake domains, respectively (Busch et al. 1997; Busch et al. 1996; Cureton et al. 1997). The Mazinaw terrane was subsequently cooled below the hornblende cooling temperature by ca. $950 \mathrm{Ma}$ (Cosca et al. 1991; Busch et al. 1996), finally reaching shallow crustal levels by ca. $590 \mathrm{Ma}$ (Kamo et al. 1995)

\subsubsection{Grimsthorpe domain - Skootamatta pluton}

The Skootamatta pluton is located in the eastern part of the Grimsthorpe domain (figures 1.1, 1.2, 2.1). This part of the domain is bounded by the Partridge Creek shear zone to the west and the Mooroton shear zone to the east (Easton and Ford 1994). The geology of this area is dominated by $>1267 \mathrm{Ma}$ supracrustal mafic metavolcanic rocks and minor volcanic conglomerates intruded by gabbro, leucogabbro (preserving igneous layering), anorthosite and ultramafic rocks of the Killer Creek gabbro. Both the supracrustal and intrusive rocks were intruded by the ca. 1267 Ma Elzevir tonalite (figures 1.1a, 1.2a: Lumbers et al. 1990). The rocks in the eastern part of the Grimsthorpe domain have all been metamorphosed to greenschist facies (age of metamorphism uncertain) and show little, if any evidence of strain. The rocks of the Grimsthorpe domain are interpreted to have a primitive arc affinity (Easton and Ford 1994).

\subsubsection{Sharbot Lake domain - Cranberry Lake pluton}

The geology of the Sharbot Lake domain in the vicinity of the Cranberry Lake pluton (figures 1.1a, 1.3a) comprises ca. 1240 Ma amphibolite, metagabbro, mafic to felsic metavolcanic, pyroclastic rocks and marbles (Corfu 
and Easton 1997; Easton 2001). These rocks have all been penetratively deformed and metamorphosed at ca. $1170 \mathrm{Ma}$ (Corfu and Easton 1997) to produce strong mineral foliations striking to the northwest, and dipping to the northeast. Adjacent to the Robertson Lake shear zone, there are prominent mylonites, dipping $15-20^{\circ}$ to the east, displaying hematite and epidote alteration cut by quartz vein stockwork. The Cranberry Lake pluton cuts across the regional structural trends, appears to have been emplaced concordant to the Robertson Lake shear zone, has an irregular map pattern and has a strong mineral foliation (figure 1.3a: Easton 2001a; 2001b).

\subsubsection{The Sharbot Lake domain - Elphin and Barbers Lake pluton}

The Elphin and Barbers Lake plutons are located in the central area of the Sharbot Lake domain (figure 1.1; 1.3b). The Elphin pluton intruded the massive, medium- to coarse-grained ca. $1224 \mathrm{Ma}$ Lavant gabbro (figure 1.3b: Corfu and Easton 1997). The Barbers Lake pluton intruded the Dalhousie pyroxenitegabbro amphibolite complex, locally bedded marbles and polydeformed mafic metavolcanic rocks, that strike to the northeast, and dip moderately to the southeast (figure 1.3b). There are $U$ - and Th-rich pegmatite veins associated with the Barbers Lake pluton (Easton 2008).

\subsubsection{The Sharbot Lake domain - McLean and Leggat Lake plutons}

The southern part of the Sharbot Lake domain, in the vicinity of the McLean and Leggat Lake plutons is dominated mafic to intermediate metavolcanic rocks, and minor marbles and siliciclastic metasedimentary rocks of the Grenville Supergroup that were intruded by the ca. 1255 Ma (Wallach 1973) 
Hinchinbrooke tonalite gneiss and the sub-circular dioritic ca. 1154 Ma Mountain Grove pluton (figures 1.1a and 1.3c: Davidson and van Breemen 2000c). The youngest age for the Grenville Supergroup in this area is constrained by the age of the Hinchinbrooke tonalite gneiss.

There have been multiple phases of deformation as evidenced by foliations striking east-northeast and dipping moderately- to steeply to the southsoutheast and regional map-scale refolded isoclinal folds (figure 1.3c). The most recent phase of deformation and metamorphism is dated at ca. $1170 \mathrm{Ma}$ (Corfu and Easton 1997). The Leggat Lake and Mclean plutons cut across the regional structural trends, and the McLean pluton is bounded to the west by the Robertson Lake shear zone (figure 1.3c).

\subsubsection{The Frontenac terrane - Westport area plutons}

Around the Westport area plutons, the geology consists of marbles interlayered with quartzofeldspathic gneiss and two separate quartzite units, intruded by the ca. 1190-1160 Frontenac intrusive suite (figures 1.1a and 1.2b; Davidson and van Breemen 2000b). Detrital zircons from the upper quartzite indicate deposition after ca. $1306 \mathrm{Ma}$, whereas those from the lower quartzite indicate deposition after ca. 1400 Ma (Chiarenzelli et al. 2013; Wynne-Edwards 1967; Sager-Kinsman and Parrish 1993). The rocks have been both metamorphosed and deformed at ca. $1170 \mathrm{Ma}$ (Corfu and Easton 1997) with foliations trending north-northeast, and moderately dipping to the southsoutheast and at least two generations of map-scale regional folds (figure 1.2b). The Westport area plutons do not follow the regional structural trends and are 
bounded to the south by the Rideau Lake fault (Figure 1.2b). Note that the Rideau Lake pluton may in fact, comprise 2 separate bodies. Sampling was focussed on the western of the 2 bodies. 


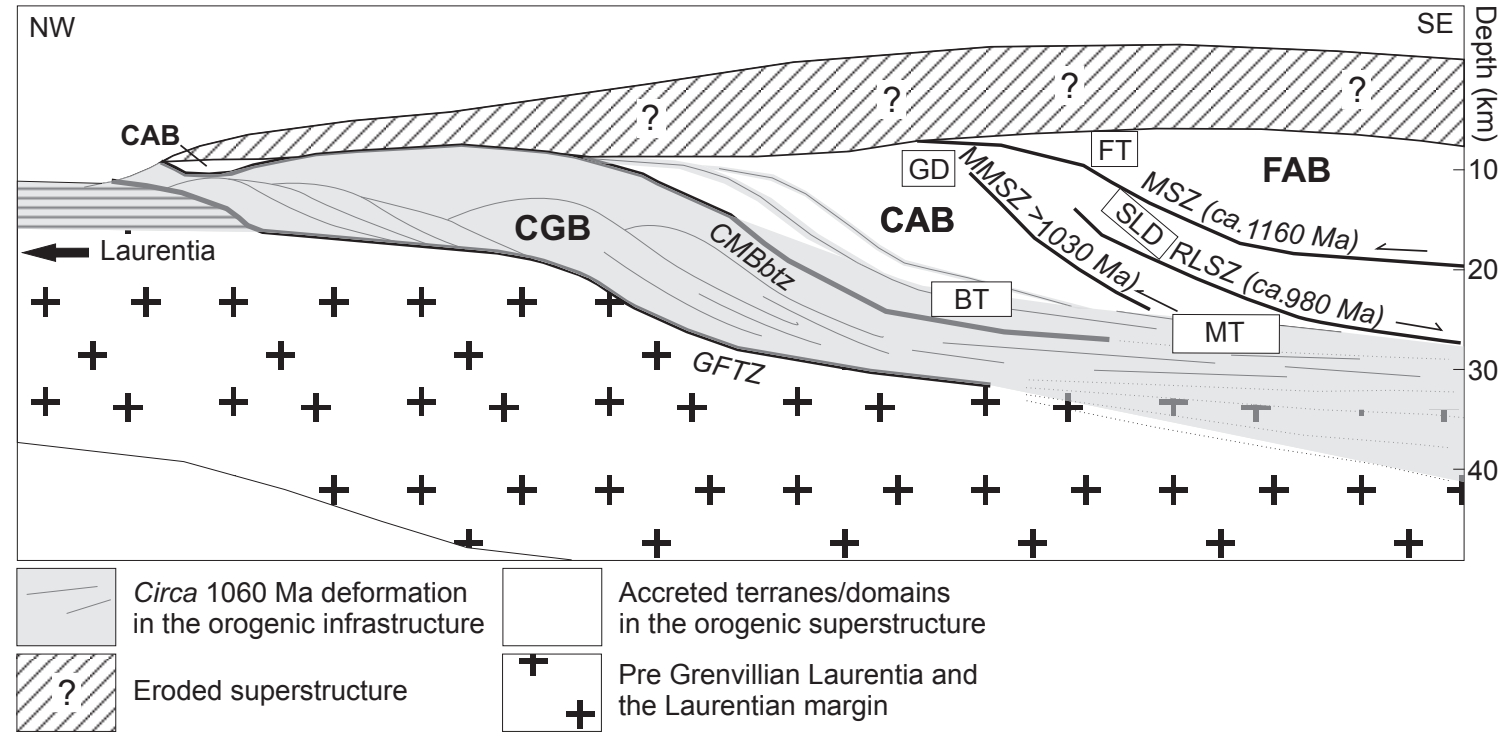

Figure 2.1: Schematic cross-section of the Grenville Province at ca. $1060 \mathrm{Ma}$ showing the relative structural levels of the constituent terranes and domains. This cross-section follows the model of White et al. (2000), whereby preGrenvillian Laurentia and the Laurentian margin extend beneath the CAB and the CMBbtz and CGB represent zones of ductile deformation during Ottawan orogenesis. The terranes, domains and regions that were located within the orogenic infrastructure (grey) were undergoing penetrative deformation and metamorphism at ca. $1060 \mathrm{Ma}$. The terranes and domains that were located in the orogenic superstructure (white) remained unaffected by ca. $1060 \mathrm{Ma}$ orogenesis. Domains and terranes are: BT-Bancroft Terrane; CAB-Composite Arc Belt CGB-Central Gneiss Belt; FAB-Frontenac Adirondack Belt; FTFrontenac Terrane; GD-Grimsthorpe Domain; MT-Mazinaw Terrane; and SLDSharbot Lake Domain. Shear zones or faults are: CMBbtz-Central Metasedimentary Belt boundary thrust zone; GFTZ-Grenville Front Tectonic Zone; MSZ-Maberly Shear Zone; MMSZ-Mooroton Shear Zone; RLSZRobertson Lake Shear Zone. 


\section{CHAPTER 3 - GEOCHEMISTRY}

Petrography and geochemistry studies were undertaken to characterize the nine plutons in this study and to determine their tectonic and melt origins. These data will be used to establish similarities and differences of the syenitemonzonite and granite-monzogranite plutons.

\subsection{Geochemistry methods}

Samples were trimmed and chipped in the field to remove weathered surfaces and to facilitate the crushing procedure, sample preparation, and dissolution chemistry which were all carried out at GeoScience Laboratories, Ontario Geological Survey, in Sudbury, Ontario. Major and trace elements for all samples were analysed also at GeoScience Laboratories. Forty-three syenitemonzonite samples were analyzed: 10 from the Wolfe Lake and Rideau Lake plutons, 11 from the Foley Mountain pluton and 12 from the Skootamatta syenite. Previously published major and trace element analyses from 26 samples; excluding REEs, from Easton and Ford (1994), were included to complement the data-set. Twenty-four granite-monzogranite samples were analyzed: 3 from Barbers Lake granite, 10 from the Elphin and Leggat Lake plutons, 11 from the McLean pluton and 2 from the Cranberry Lake pluton. In addition, 11 samples from the Barbers Lake pluton, collected by Ken Ford of the Geological Survey of Canada (unpublished data), were re-analysed for this study. All 89 samples were crushed then powdered in an agate ball mill. Dissolution for trace element analysis was done using a closed vessel multi-acid digestion. Analysis for major 
elements was carried out using X-ray fluorescence (XRF), and minor and trace elements where analysed using a combination of XRF, inductively coupled plasma - mass spectrometry (ICP-MS), and inductively coupled plasma - atomic emission spectroscopy (ICP-AES). Furthermore, some samples were analysed for carbon and sulphur using infrared absorption, and ferrous iron using titration. Representative geochemical analyses for each pluton are presented in table 3.1 alongside analyses from Corriveau et al. (1990).

$\mathrm{Sm} / \mathrm{Nd}$ and $\mathrm{Sr}$ isotopic analyses were carried out on two samples from each syenite pluton, 4 samples from the Barbers Lake pluton, 3 from each of the Elphin and Leggat Lake plutons, 2 from the McLean pluton and 1 from the Cranberry Lake pluton. The samples were crushed and powdered at Geoscience Laboratories in Sudbury, Ontario. Sample powder dissolution and chemistry were completed at the Isotope Geochemistry and Geochronology Research Centre (IGGRC) at Carleton University following chemical techniques outlined by Cousens (1996). Sm/Nd samples were analysed using isotope dilution - thermal ionization mass spectrometry (ID-TIMS) using a ${ }^{148} \mathrm{Nd}-{ }^{149} \mathrm{Sm}$ spike with reproducibility of \pm 0.0000012 . Uncertainty on $\varepsilon N d$ values is $\sim 0.5$. Sr isotopic analyses were carried out using thermal ionization mass spectrometry (TIMS) methods; detailed descriptions of dissolution chemistry, column chemistry techniques, and mass spectrometry are summarized in appendix $A-M R D 311$. $\mathrm{Sr}$ and $\mathrm{Sm}-\mathrm{Nd}$ isotopic analyses are presented in table 3.2. Uncertainties are presented at the $2 \sigma$ level. 


\subsection{Results}

The plutons of the Kensington-Skootamatta suite are divided into two geochemical suites on the basis of their rock-type (Easton 2008) and geochemistry signatures; a syenite-monzonite suite (figure 1.2) and a granitemonzogranite suite (figure 1.3). (Note: the use of the term suite is on the basis of similar rock types rather than indicating a formal lithostratigraphic unit). The plutons from this study that are included in the syenite-monzonite suite are the Skootamatta and the Westport area plutons, and the plutons from this study that are included in the granite-monzogranite suite are the Barbers Lake, Leggat Lake, and McLean plutons. Geochronology results for the Elphin and Cranberry Lake plutons (Cutts, Chapter 4) exclude them from the Kensington-Skootamatta suite.

\subsubsection{Syenite-monzonite suite}

The Skootamatta and Westport area plutons are included in the syenitemonzonite suite. In general, these plutons consist of medium- to coarse-grained, equigranular to bimodal grain size, biotite-rich syenite to monzonite to quartz monzonite rocks. The Westport area plutons show little variation in grain-size or rock-type whereas the Skootamatta syenite varies from biotite-syenite to monzonite to monzodiorite, and locally has up to $40 \%$ biotite. The plutons are on average K-feldspar- and plagioclase-rich, with minor quartz and biotite, and trace amounts of hornblende, garnet, pyrite, zircon and apatite. The Foley Mountain and Rideau Lake plutons show some localised variation in their proportions of Kfeldspar (20-50\%) and plagioclase (15-50\%). Photomicrographs show localised 
micrographic intergrowth between quartz and potassium feldspar. There is $\sim 5$ $10 \%$ sericitic alteration. See figure 3.1 for representative photographs and photomicrographs for each syenite-monzonite pluton.

The geochemical data (table 3.1) plot in the trachyte to monzonite to syenite fields on a total alkali-silica rock classification diagram (figure 3.2a), and are characterised by dominantly alkaline, shoshonitic and metaluminous compositions (figure 3.2a-c). Furthermore, they are primarily classified as ferroan and alkalic on the Frost et al. (2001) classification diagrams for granitoids (figure 3.2d-e). The three Westport area plutons cluster similarly on major element plots (figure 3.2a-e). Skootamatta samples, however, show a greater range of major element abundances. This is consistent with the greater range of rock-types observed within the pluton.

On primitive mantle-normalised extended multi-element plots, the syenitemonzonites are characterised by prominent negative $\mathrm{Ti}, \mathrm{Sr}$, and $\mathrm{P}$ anomalies, and a minor $\mathrm{Nb}$ anomaly (figure 3.3a), LREE enrichment (Westport area $\mathrm{La}_{\mathrm{n}} / \mathrm{Sm}_{\mathrm{n}}$ 2-4, Skootamatta $\mathrm{La}_{n} / \mathrm{Sm}_{\mathrm{n}} \sim 3-4.5$ : figure 3.3a), and low HREE enrichment (Westport $\mathrm{Gd}_{n} / \mathrm{Yb}_{\mathrm{n}} \sim 1.5-3$; Skootamatta $\mathrm{Gd}_{n} / \mathrm{Yb}_{n} \sim 1.5-4.5$ : figure 3.3a, e). The Foley Mountain and Rideau Lake plutons appear to have two trace element patterns; one set with a flatter curve (higher HREE), and minor Sr and P anomalies, and a second set that has the opposite pattern (figure 3.3a). Relative to the Westport area plutons, the Skootamatta pluton has non-depleted $U$ and Th anomalies and a slight negative $\mathrm{Nb}$ anomaly. The Westport area plutons have $\mathrm{Th}$ and $U$ concentrations of 3-10 ppm and 0.5-3.1 ppm, respectively, whereas the 
Skootamatta pluton has Th and $U$ concentrations of 1-82 ppm and 0.6-8 ppm, respectively.

On chondrite-normalised REE plots, both the Wolfe Lake and the Skootamatta plutons consistently do not exhibit Eu anomalies, whereas two samples from Rideau Lake pluton and six from the Foley Mountain pluton have higher overall REEs and negative Eu anomalies (figure 3.3e). The samples with higher HREE and negative Eu anomalies have a more intense pink-red colouration in hand sample and a higher proportion of K-feldspar (syenites), whereas the samples with lower HREE and neutral or positive Eu anomalies have a more pink-grey colouration in hand sample, and a higher proportion of plagioclase (monzonite). Relative to the other plutons, the Skootamatta pluton overall has a steeper REE pattern.

In the Pearce et al. (1984) tectonic discrimination diagram for granitoids, samples from the Skootamatta pluton plot in the volcanic arc granite (VAG) field, whereas the Westport area plutons plot in the within plate granite (WPG) to anomalous ocean-ridge granite fields (AORG: figure 3.4a). In the Whalen et al. (1987) tectonic discrimination diagrams for A-type granitoids, both the Skootamatta and Westport area plutons dominantly plot as A-type (figure 3.4b). On the Eby (1992) sub-classification diagram for A-type granitoids, the Skootamatta pluton plots as $\mathrm{A}_{2}$; representing melts contaminated by partial melting of continental lithosphere whereas, the Westport area plutons plot as $A_{1}$; representing mantle differentiates (figure 3.3c). 
Two samples from each of the four syenite-monzonite plutons were selected for $\mathrm{Sr}$, and $\mathrm{Sm} / \mathrm{Nd}$ isotopic analysis. In general, the samples from the four plutons yielded $\varepsilon_{\mathrm{Nd}}$ values of 1.88 to 5.07 , although one sample from the Foley Mountain pluton yielded a more contaminated $\varepsilon_{N d}$ value of -0.40 . Overall, these values suggest derivation of the melt from a depleted source. $T_{D M}$ model ages range from 1196-1802 Ma. Initial Sr values are less diagnostic; however, they still suggest derivation of the melt from a depleted source (figure 3.5, table $3.2)$.

\subsubsection{Granite-monzogranite suite}

The Barber's Lake, McLean and Leggat Lake plutons are included in the granite-monzogranite suite. In general, these plutons consist of fine- to coarsegrained, equigranular to bimodal grain-size, granite to syenogranite to monzogranite to quartz syenite. Due mainly to the higher proportion of quartz in the mineralogy of the granite-monzogranite plutons than in the syenite-monzonite plutons, the granite-monzonite plutons have a greater range in rock-type both within each pluton and between plutons of the suite. In general, the plutons are K-feldspar, plagioclase and quartz rich with minor biotite, and hornblende along with trace amounts of chlorite, pyrite, garnet, apatite and zircon.

Photomicrographs show abundant micrographic intergrowth between potassium feldspar and quartz; particularly in the Barbers Lake pluton. See figure 3.6 for representative photographs and photomicrographs for each granitemonzogranite pluton. The McLean pluton is relatively homogeneous in both modal abundance and grain size, whereas, the Leggat Lake pluton ranges from 
fine- to coarse-grained and from granite to alkali feldspar granite to syenite. The Leggat Lake pluton is unique in that the grain-size appears to be related to the location within the pluton; fine-grained at the margin, coarse-grained at the center. The other plutons show no correlation between grain-size and spatial distribution. There are localized occurrences of tourmaline veins in the Barbers Lake pluton. All of the plutons have minor amounts of sericitic alteration (see appendix $A-M R D$ 311).

The data dominantly plot as monzogranite to granite to quartz monzonite on a total alkali-silica rock classification diagram (figure $3.2 a$ ), and are characterised by dominantly alkaline and metaluminous to peraluminous compositions (figure 3.2a-c). On Frost et al. (2001) classification diagrams for granidoids, the data dominantly plot as ferroan and alkalic (figure 3.2d-e). The Barbers Lake data are easily distinguished from the other granites by their higher $\mathrm{SiO}_{2}$ content. The Barbers Lake data plot as sub-alkaline (TAS: figure 3.2a), high-K calc-alkalic and alkali-calcic (figure $3 \cdot 2 b-d$ ).

On primitive mantle-normalised extended multi-element plots, the granitemonzogranite samples are characterised by prominent negative $\mathrm{Ba}, \mathrm{Ti}, \mathrm{Sr}$, and $\mathrm{P}$ anomalies, a minor $\mathrm{Nb}$ anomaly and a shallow negative trend; similar to the Westport area plutons, with LREE enrichment (e.g. Leggat Lake, McLean and Barbers Lake have $\mathrm{La}_{\mathrm{n}} / \mathrm{Sm}_{\mathrm{n}}$ 1.5-4: figure 3.3b), and low HREE enrichment (Leggat Lake, McLean, and Barbers Lake $\mathrm{Gd}_{n} / \mathrm{Yb}_{n} \sim 1-1.4$ : figures 3.3b, f). Barber's Lake samples are distinguishable from the other granites by a greater depletion in $\mathrm{Ba}, \mathrm{La}, \mathrm{Ce}$ and $\mathrm{Ti}$ and greater enrichment in $\mathrm{U}$, Th and $\mathrm{Pb}$ (figure 
3.3b). The Leggat Lake and McLean plutons have Th and $U$ concentrations of 3.8-58 ppm and 1.2-6.4 ppm, respectively, whereas the Barber's Lake pluton has Th and $U$ concentrations of 25-109 ppm and 5.5-90 ppm, respectively.

On a chondrite-normalised REE plot, the granites dominantly have pronounced negative Eu anomalies $\left(E u / E u^{*}=\sim 0.1-0.5\right.$ figure 3.3f). Three samples from the granite-monzogranite suite have different chondrite-normalised REE profiles than the other granite-monzogranite samples; and include sample JC-061 from the Leggat Lake intrusion and samples JC-001 and BL32 from the Barbers Lake intrusion. Sample JC-061 has a REE profile with a much steeper slope than the other granite-monzogranite samples with a concave up pattern. Samples JC-001 and BL-32 have much lower LREE concentrations than the other granite-monzogranite samples.

In the Pearce et al. (1984) tectonic discrimination diagram for granitoids, the data from the granite-monzogranite plutons plot in the WPG and AORG fields (figure 3.4a). On the Whalen et al. (1987) tectonic discrimination diagrams for Atype granitoids, the Barbers Lake data plot in the fractionated granite $(F G)$ and the M/I/S-type granite (OGT) fields, whereas, the remaining granites plot in the Atype field (figure 3.4b). On an A-type sub-classification scheme of Eby (1992), the granites uniformly plot in the $A_{2}$ field; representing melts contaminated by partial melting of the continental lithosphere. Only the Barbers Lake pluton shows some ambiguity, with some data partially plotting in the $A_{1}$ field, which represents mantle differentiates (figure 3.4c). 
Four samples from the Barbers Lake pluton, 2 from the McLean pluton, and 3 from the Leggat Lake pluton were selected for $\mathrm{Sr}$, and $\mathrm{Sm}-\mathrm{Nd}$ isotopic analysis. In general, these samples yielded $\varepsilon_{\mathrm{Nd}}$ values of +1.52 to +4.58 , although 1 sample from the Barbers Lake pluton yielded a contaminated $\varepsilon_{\mathrm{Nd}}$ value of -6.39 . $\mathrm{T}_{\mathrm{DM}}$ model ages range from 1333-1997 Ma. Initial $\mathrm{Sr}$ ratios are less definitive, likely due to element mobility; however, they may be consistent with derivation of the melt from a depleted source (figure 3.5, table 3.2).

\subsubsection{The Cranberry Lake pluton}

The ca. $1157 \mathrm{Ma}$ Cranberry Lake pluton is part of the Frontenac intrusive suite (Cutts, Chapter 4) and consists of medium- to coarse-grained, foliated granite to alkali feldspar granite. It is dominantly composed of K-feldspar, plagioclase feldspar and quartz with minor biotite and trace hornblende. There is a strong mineral foliation evident by the alignment of biotite, hornblende and quartz ribbons (figure 3.6f). Along fracture planes at outcrop scale, veins have undergone epidote alteration.

Geochemical data from the two Cranberry Lake samples plot in the granite field on a total alkali-silica rock discrimination diagram, and are characterised by shoshonitic and metaluminous compositions (figure 3.2a-c). On the Frost et al. (2001) classification diagrams for granitoids, the data plot in the ferroan and alkalic fields (figure $3.2 d-e$ ).

On a primitive mantle-normalised extended multi-element plot, the Cranberry Lake pluton is characterised by prominent negative $\mathrm{Ti}, \mathrm{Sr}, \mathrm{P}$, and $\mathrm{Nb}$ 
anomalies and a shallow negative trend with LREE enrichment $\left(\mathrm{La}_{n} / \mathrm{Sm}_{n} \sim 2-3\right)$, and low HREE enrichment $\left(\mathrm{Gd}_{n} / \mathrm{Yb}_{\mathrm{n}} \sim 1\right.$-1.4: figure 3.3c). On a chondritenormalised REE plot, the Cranberry Lake granite has a pronounced negative Eu anomaly $\left(\mathrm{Eu}^{\mathrm{E}} \mathrm{Eu}^{*}=\sim 0.1-0.5\right.$ : figure $\left.3.3 g\right)$.

On various tectonic discrimination diagram for granitoids, the data from the Cranberry Lake pluton plot as a WPG to AORG (figure 3.4a: Pearce et al. 1984), as anorogenic granites (figure 3.4b: Whalen et al. 1987), and as having a melt contaminated by partial melting of the continental lithosphere (figure 3.4c: Eby 1992).

One sample from the Cranberry Lake pluton was selected for Sr and Sm$\mathrm{Nd}$ isotopic analysis. Analysis of this sample yielded an $\varepsilon N d$ value of 4.50 , a $\mathrm{T}_{\mathrm{dm}}$ age of $1339 \mathrm{Ma}$ and an initial $\mathrm{Sr}$ value of 0.70196 (figure 3.5; table 3.2).

\subsubsection{The Elphin pluton}

The ca. $1178 \mathrm{Ma}$ Elphin pluton is part of the Frontenac intrusive suite (Chapter 4) and ranges in rock-type and texture from fine- to coarse-grained granite to alkali feldspar granite to syenite to monzonite. It is dominantly composed of K-feldspar, plagioclase feldspar, quartz minor biotite and trace hornblende. There is a localised weak mineral foliation with minor sericitic alteration throughout the intrusion (figure 3.6b).

Samples from the Elphin pluton dominantly plot in the granite and syenite fields on a total alkali-silica rock classification diagram. Sample JC-012; a biotiterich ( $20 \%)$ sample, plots in the nepheline syenite field; however, there is no 
petrographic evidence to support its designation as such. Samples from the Elphin pluton are further characterised by calc-alkaline/high-K calc-alkaline to shoshonitic and metaluminous to peraluminous compositions (figure 3.2a-c). On the Frost et al. (2001) classification diagrams for granitoids, the samples plot in the ferroan to magnesian and alkalic fields (figure 3.2d-e).

On a primitive mantle-normalised extended multi-element plot the Elphin pluton data are characterised by prominent negative $\mathrm{Ti}, \mathrm{P}$, and $\mathrm{Nb}$ anomalies and a steeper negative trend than the other plutons in this study with LREE enrichment $\left(\mathrm{La}_{n} / \mathrm{Sm}_{\mathrm{n}} \sim 2-3\right)$, and low HREE enrichment $\left(\mathrm{Gd}_{n} / \mathrm{Yb}_{n} \sim 3\right.$ : figure 3.3d,h). On a chondrite-normalised REE plot, the Elphin pluton data do not have a Eu anomaly and are depleted in HREEs relative to all of the other plutons in this study (figure 3.3h).

On various tectonic discrimination diagrams for granitoids, the Elphin pluton plots as a VAG (figure 3.4a; Pearce et al. 1984), a fractionated granite (figure 3.4b; Whalen et al. 1987), and as having a melt contaminated by partial melting of the continental lithosphere (figure 3.4c; Eby 1992).

Three samples from the Elphin pluton were selected for Sr and Sm-Nd isotopic analysis. These sample yielded positive to slightly negative $\varepsilon \mathrm{Nd}(-$ -1.11 to $4.48, \mathrm{~T}_{\mathrm{dm}}$ ages of $1318-1946 \mathrm{Ma}$ and initial $\mathrm{Sr}$ values $(0.70224$ to 0.70323: figure 3.5; table 3.2). 


\subsection{Summary of Geochemistry Results}

- The syenite-monzonite and granite-monzogranite plutons are petrographically distinct. The syenite-monzonite plutons contain higher proportions of Kfeldspar, less quartz, and higher biotite content (10-20\%), particularly the Skootamatta syenite. The Elphin pluton also contains more biotite than the granite-monzogranite plutons (figure 3.6).

- The syenite-monzonites have lower $\mathrm{SiO}_{2}$ content ( $60 \%$ vs. $\left.66-75 \%\right)$, and higher alkali content (11\% vs. $9 \%$ ) relative to the granite-monzogranites (figure 3.2a).

- Both plutonic suites are dominantly alkalic, metaluminous to peraluminous, shoshonitic and ferroan; however, the syenite-monzonite plutons are more alkalic, more dominantly metaluminous and are less consistently ferroan than the granite-monzogranites (figure 3.2b-e).

- The multi-element profiles show depletions in the same trace elements in both suites (Nb, Sr, P, Ti; Eu on REE plot; figures 3.3a,b,e,f); however, the anomalies are more pronounced in the granite-monzogranite suite relative to the syenite-monzonite suite

- The Westport area, Barber's Lake, Leggat Lake and McLean plutons plot as within-plate granite to anomalous ocean ridge granite to volcanic arc granite.

- The Skootamatta and Elphin plutons plot as volcanic arc granites.

- The syenite-monzonite plutons and the granite-monzogranite plutons have similar $\varepsilon N d$ and initial strontium values that suggest a slightly depleted source with some possible contamination from continental crust. 
- The Skootamatta pluton has a unique major and trace element geochemistry relative to the other syenite-monzonites, and has a steeper normalised traceelement profile (lower HREE), and lacks a Eu anomaly (figures 3.3a,e).

- Compared to the other granite-monzogranites, the Barbers Lake intrusion has a greater depletion in $\mathrm{Ba}$, and greater enrichments in $\mathrm{Th}, \mathrm{U}$ and $\mathrm{Pb}$.

- The Cranberry Lake pluton is the only intrusion that appears deformed at the map-scale, and in outcrop and hand-sample.

- The Elphin pluton has a much more varied rock-type than the other plutons; based on the petrography and the total alkali-silica plot (figure 3.2a), a unique geochemistry that is consistent with more arc-like magmatism (figures 3.3d, $3.4 a-c)$ and a depleted isotopic character. 


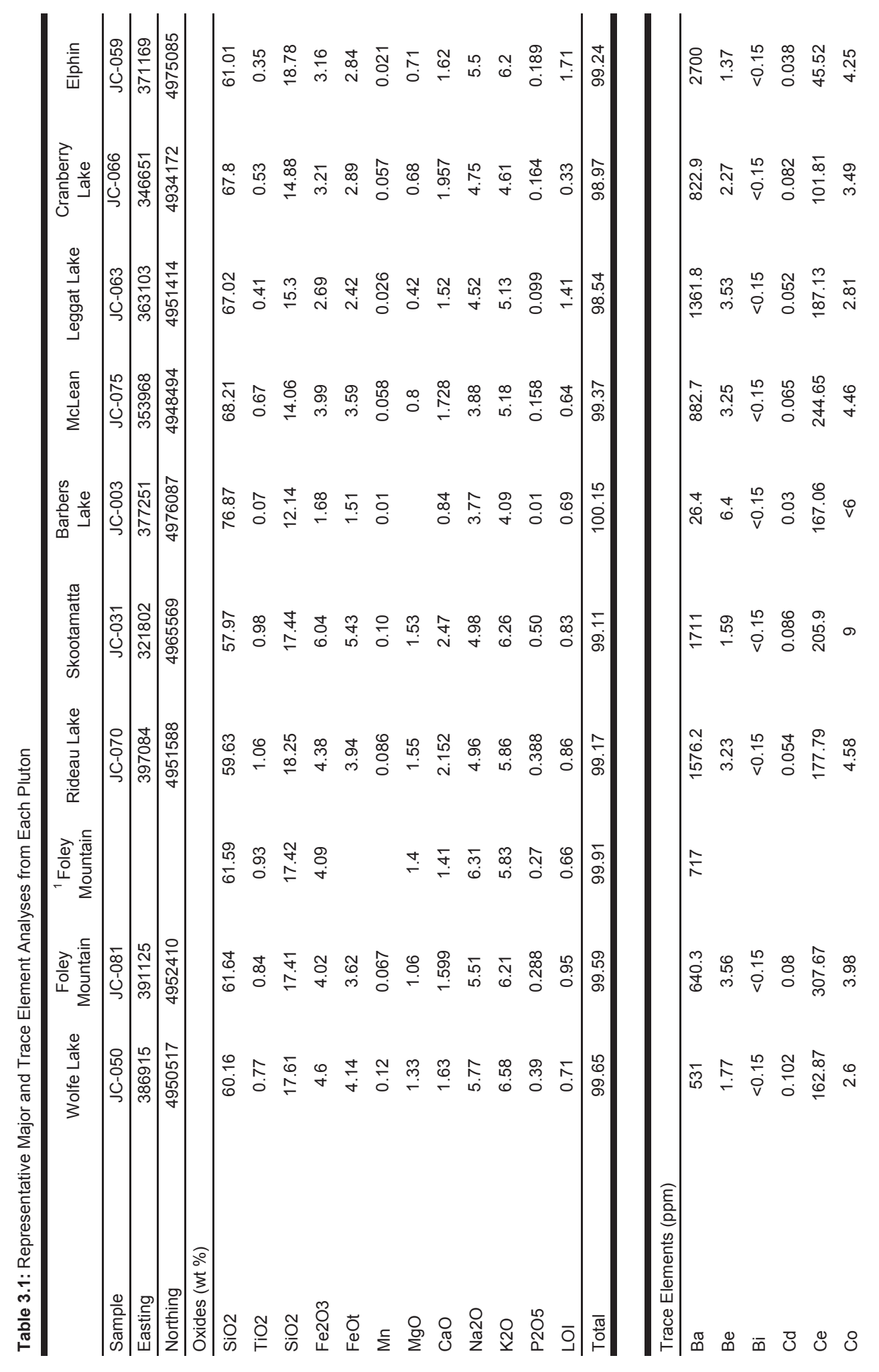




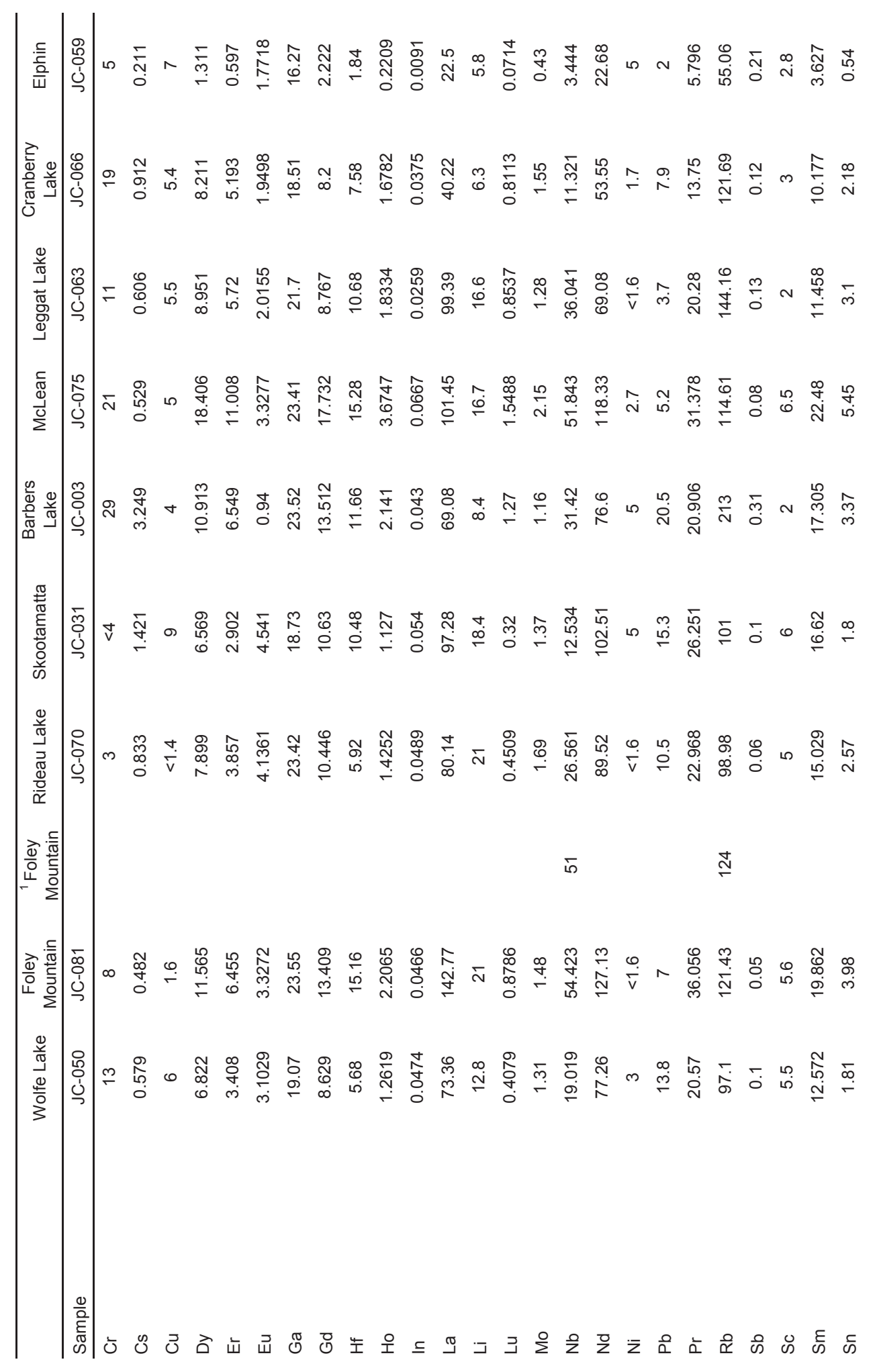




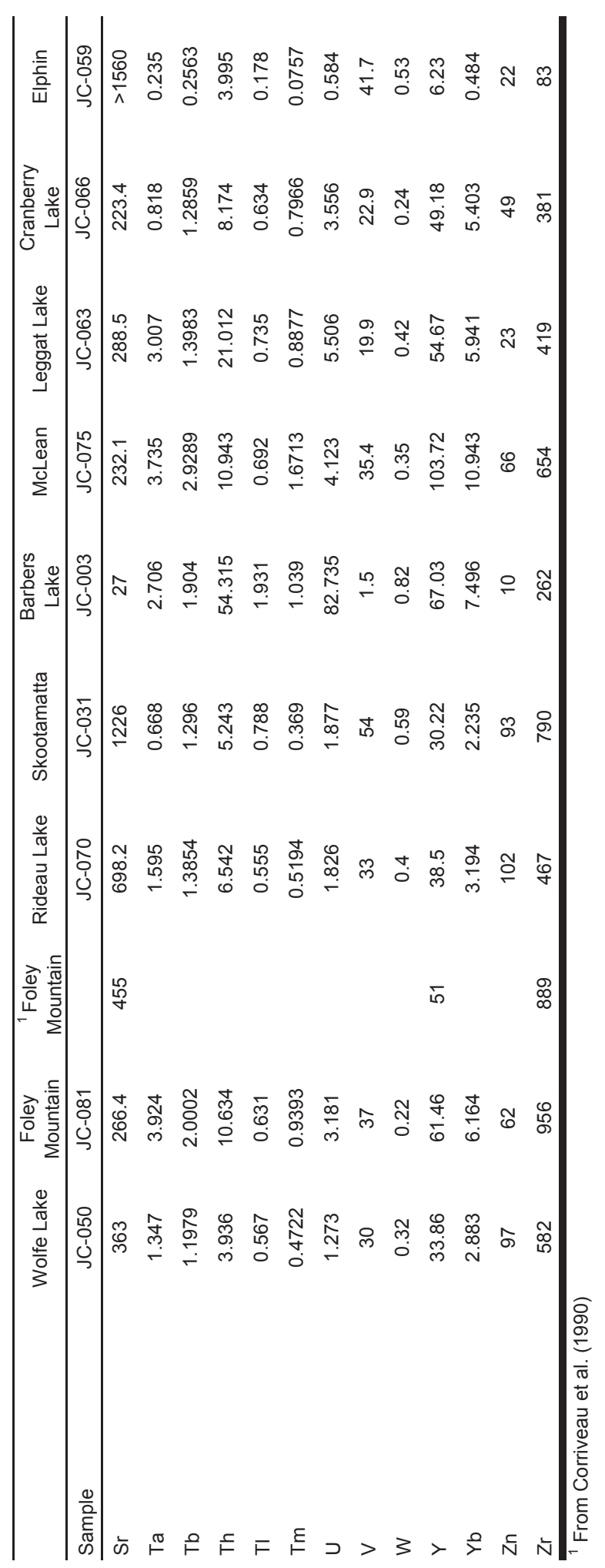




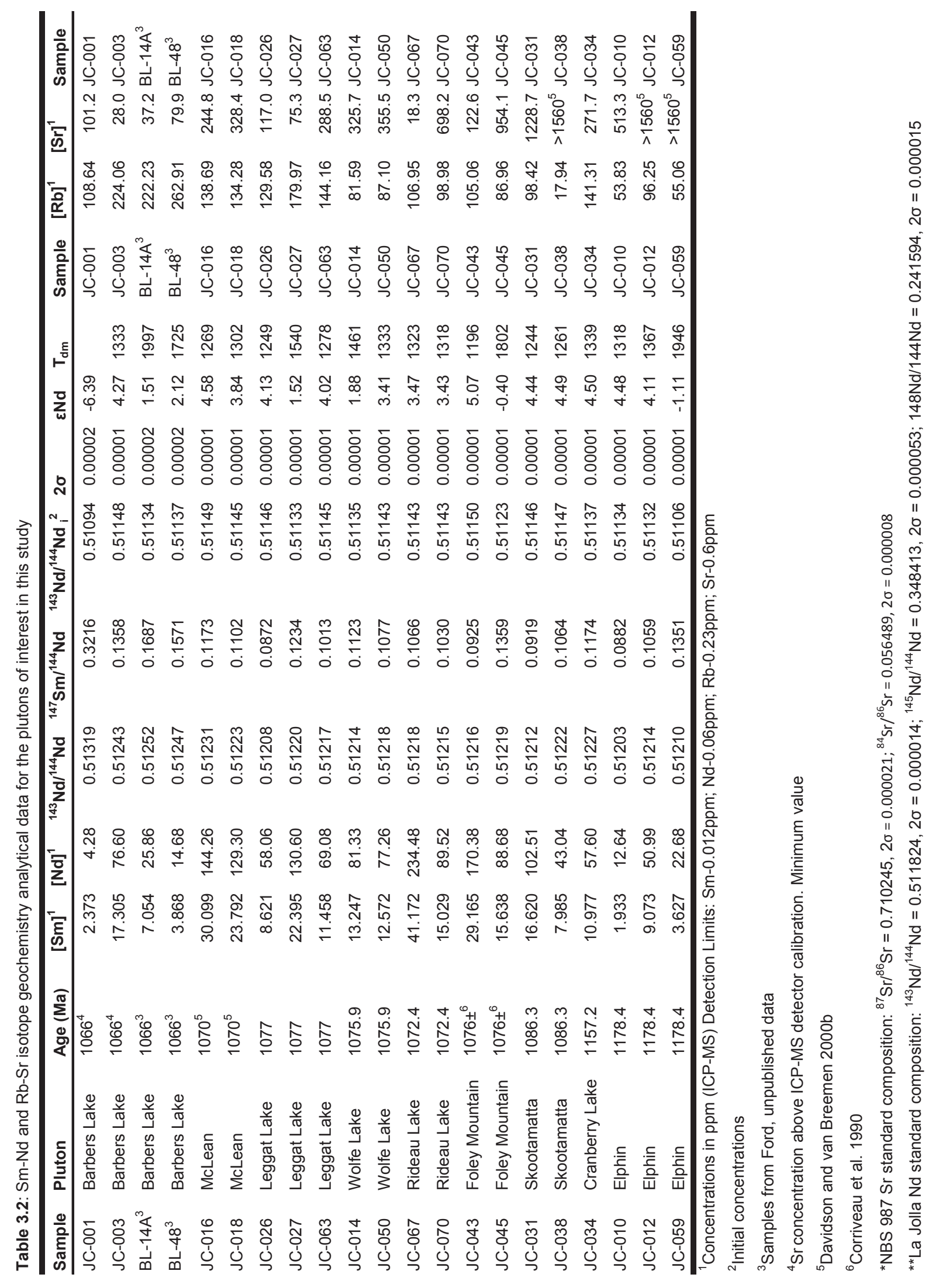




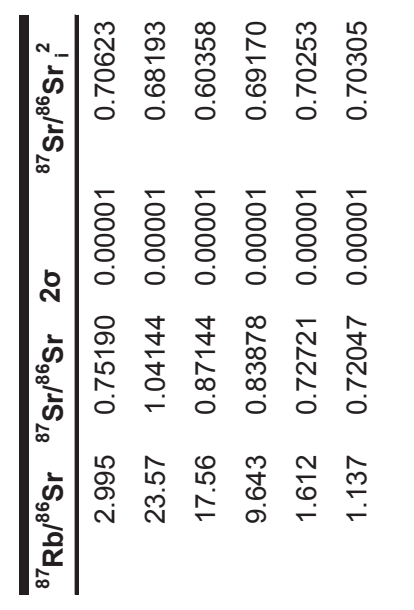

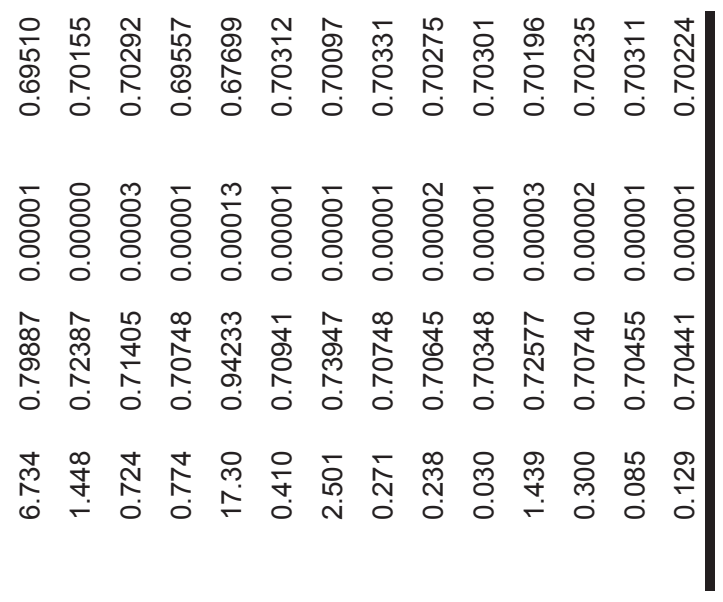



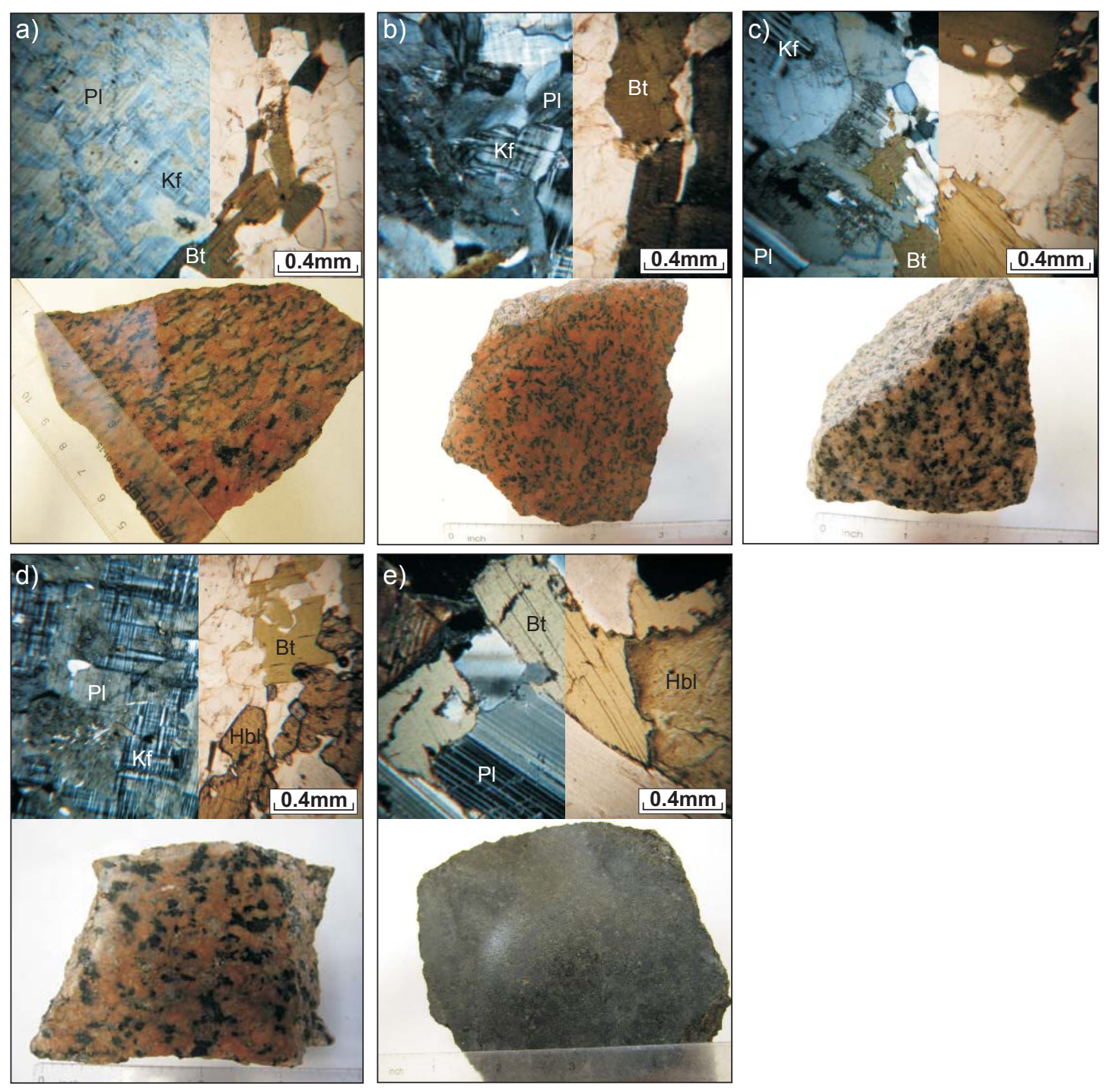

Figure 3.1: Representative photomicrographs (cross-polarised on the left, plainpolarised on the right) and corresponding sample photographs for the syenitemonzonite plutons; a) Wolfe Lake biotite-rich quartz syenite: JC-050 Coarsegrained, massive texture displaying micrographic intergrowth between Kfeldspar and plagioclase feldspar b) Foley Mountain syenite: JC-078. Coarsegrained, massive texture; c) Rideau Lake biotite-rich quartz monzonite: JC-070. Coarse-grained, massive texture; d) Skootamatta biotite-rich monzonite: JC031. Coarse-grained, massive texture displaying micrographic intergrowth between K-feldspar and plagioclase feldspar; e) Skootamatta biotite-syenite: JC-038. Coarse-grained, massive texture with very coarse biotite laths. $\mathrm{Kf}=\mathrm{K}$ feldspar; $\mathrm{PI}=$ plagioclase feldspar; $\mathrm{Qz}=\mathrm{Quartz} ; \mathrm{Bt}=$ biotite; $\mathrm{Hbl}=$ hornblende. 

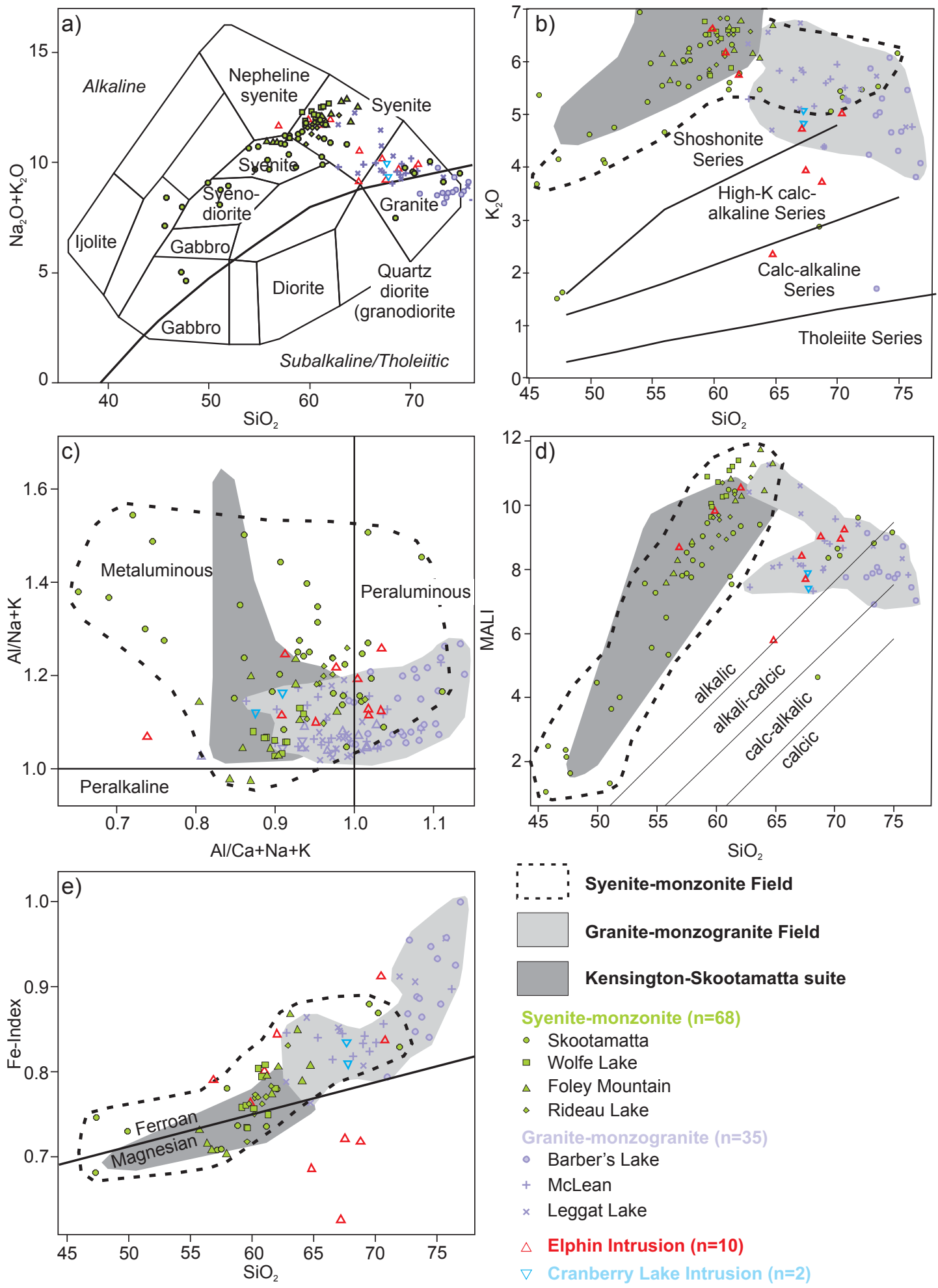
Figure 3.2: Whole-rock major element rock-classification diagrams. Symbols shown in the legend are the same for the subsequent figures 3.3, 3.4, and 3.5. The data from the Kensington-Skootamatta suite samples from Corriveau et al. (1990) are also plotted on these diagrams. a) Total alkali-silica rock-classification diagram (Cox et al. 1979). b) $\mathrm{K}_{2} \mathrm{O}$ vs. $\mathrm{SiO}_{2}$ potassium enrichment diagram (Peccerillo and Taylor 1976). c) Al/Na+K vs. Al/Ca+Na+K aluminum saturation index diagram (Shand 1943). (d) Modified Alkali Lime Index diagram (Frost et al. 2001). e) Iron-index diagram (Frost et al. 2001). See section 5.1 and 5.2 of text for interpretation 

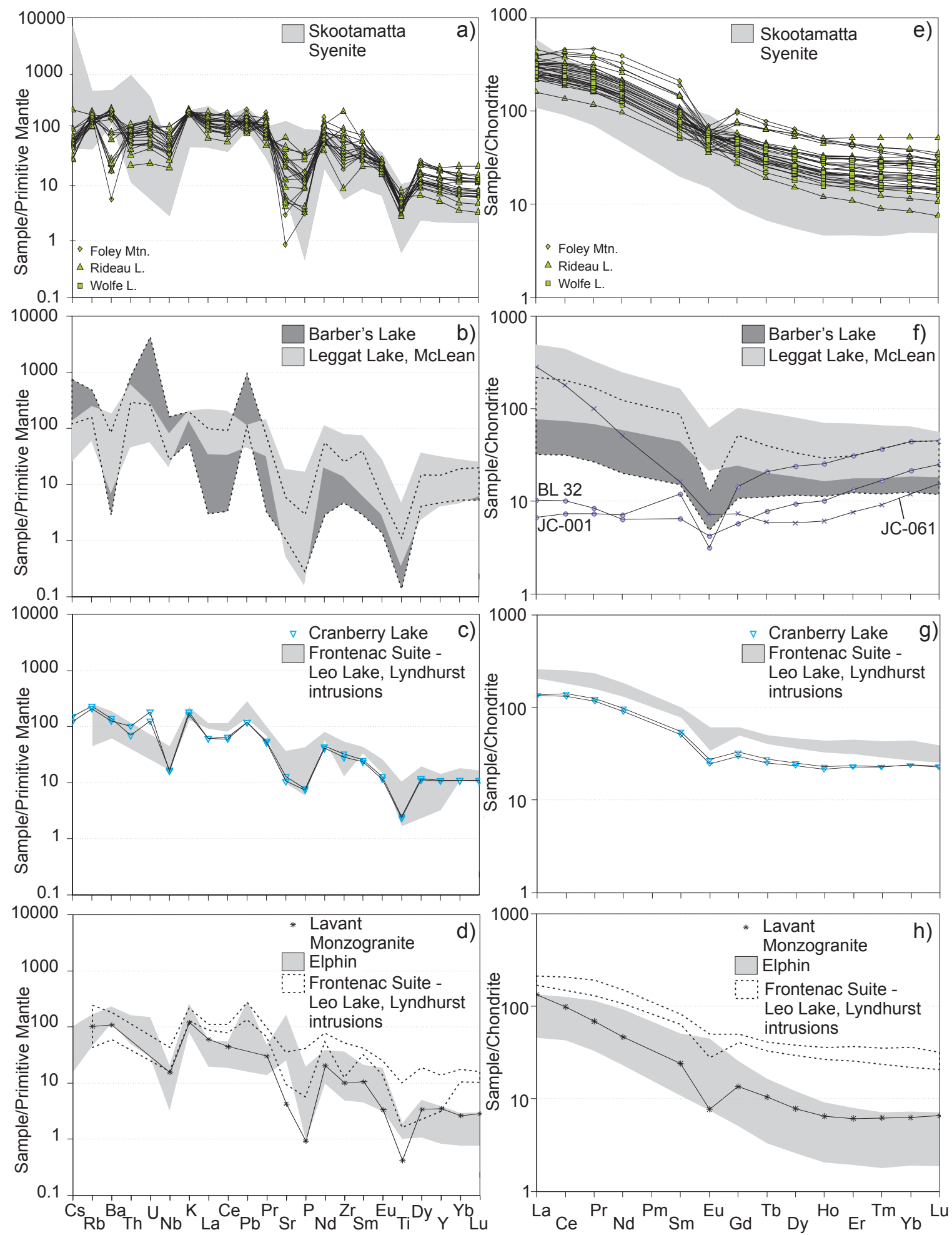
Figure 3.3: Normalised multi-element plots. a) Primitive mantle normalised multielement diagram (Sun and McDonough 1989) for syenite-monzonite pluton data. b) Primitive mantle normalised multi-element diagram (Sun and McDonough 1989) for granite-monzogranite pluton data. (c) Primitive mantle normalised multi-element diagram (Sun and McDonough 1989) for Cranberry Lake pluton data. Also plotted are data from the Lyndhurst and Leo Lake intrusions (Grammatikopoulos et al. 2007). d) Primitive mantle normalised multi-element diagram (Sun and McDonough 1989) for Elphin pluton data. Also plotted are data from the Lyndhurst and Leo Lake intrusions (Grammatikopoulos et al. 2007) and data from a monzonite sample from the Lavant intrusion (Corfu and Easton 1997). e) Chondrite normalised REE diagram (Sun and McDonough 1989) for syenite-monzonite pluton data. f) Chondrite normalised REE diagram (Sun and McDonough 1989) for granite-monzogranite pluton data. g) Chondrite normalised REE diagram (Sun and McDonough 1989) for Cranberry Lake pluton data. Also plotted are data from the Lyndhurst and Leo Lake intrusions (Grammitikopoulos et al. 2007). h) Chondrite normalised REE diagram Sun and McDonough (1989) for Elphin pluton data. Also plotted are data from the Lyndhurst and Leo Lake intrusions (Grammatikopoulous et al. 2007) and a data from a monzonite sample from the Lavant intrusion (Corfu and Easton 1997). 

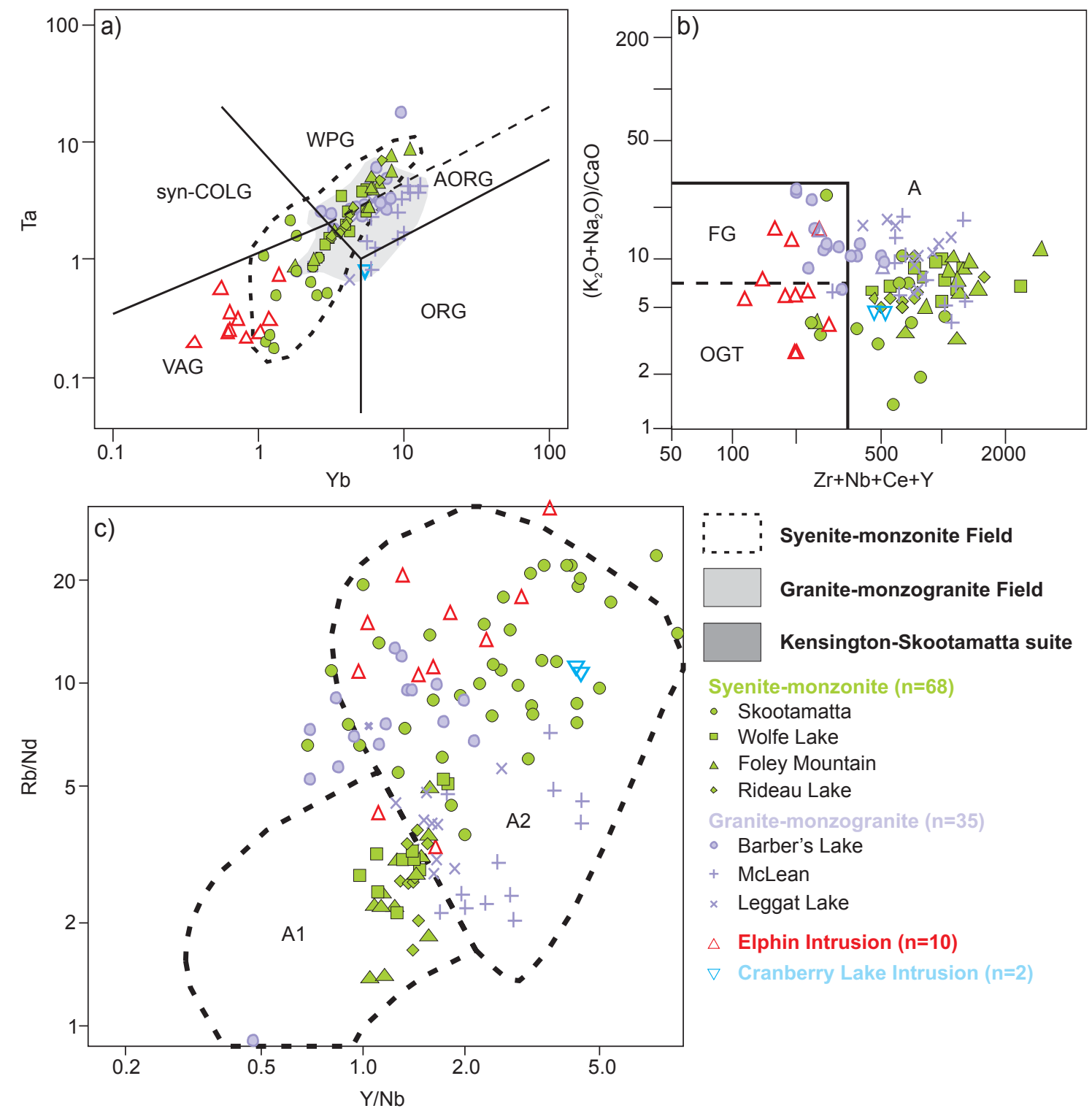

Figure 3.4: Trace-element tectonic and melt discrimination plots. a) Ta-Yb tectonic discrimination diagram for granitoids (Pearce et al. 1984). $A O R G=$ anomalous ocean-ridge granite; ORG = ocean ridge granite; syn-COLG = syn collisional granite; VAG = volcanic arc granite; $\mathrm{WPG}=$ within plate granite. $\mathrm{b}$ ) $\mathrm{FeOt} / \mathrm{MgO}$ vs. $\mathrm{Zr}+\mathrm{Nb}+\mathrm{Ce}+\mathrm{Y}, \mathrm{K}_{2} \mathrm{O}+\mathrm{Na}_{2} \mathrm{O} / \mathrm{CaO}$ vs. $\mathrm{Zr}+\mathrm{Nb}+\mathrm{Ce}+\mathrm{Y}, \mathrm{Na}_{2} \mathrm{O}+\mathrm{K}_{2} \mathrm{O}$ vs. $10000^{*} \mathrm{Ga} / \mathrm{Al}$ tectonic discrimination diagram for A-type granitoids (Whalen et al. 1987); A: A-type granitoid; FG: fractionated felsic granite, OGT: M-, I- and S-type granites. c) $\mathrm{Rb} / \mathrm{Nb}$ vs. $\mathrm{Y} / \mathrm{Nb}$ melt discrimination diagrams for A-type granitoids (Eby 1992); A1: mantle differentiates, A2: melts contaminated by partial melting of the continental lithosphere. 


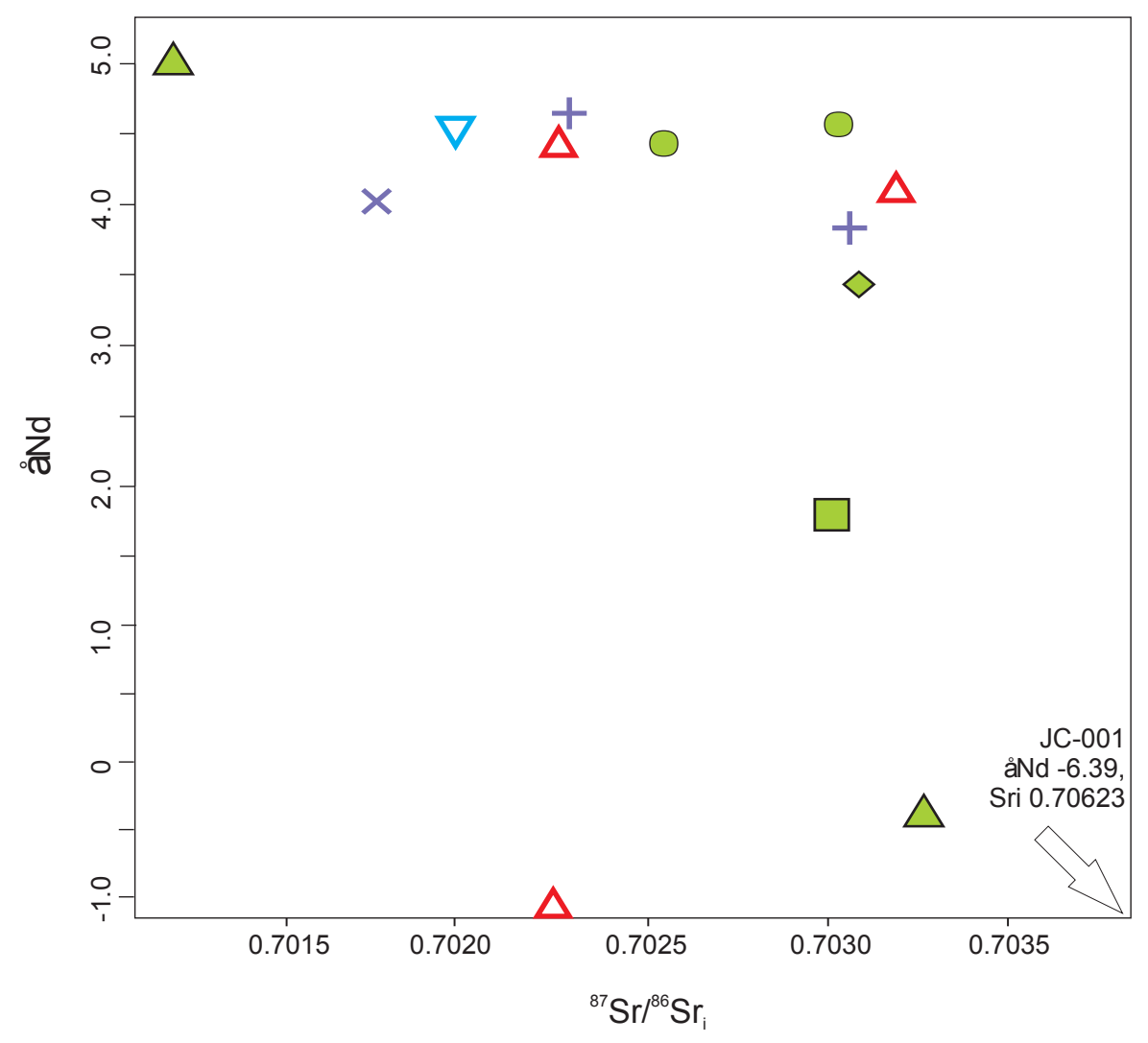

Figure 3.5: Epsilon (å)Nd vs. ${ }^{87} \mathrm{Sr} /{ }^{86} \mathrm{Sr}$ initial for syenite and granite plutons focussing on the cluster of samples from åNd-1.1-5.0 and ${ }^{87} \mathrm{Sr}^{86} \mathrm{Sr}_{\text {initial }} 0.7010$ 0.7040 . Table 3.2 shows the complete data-set of results, including outliers. 

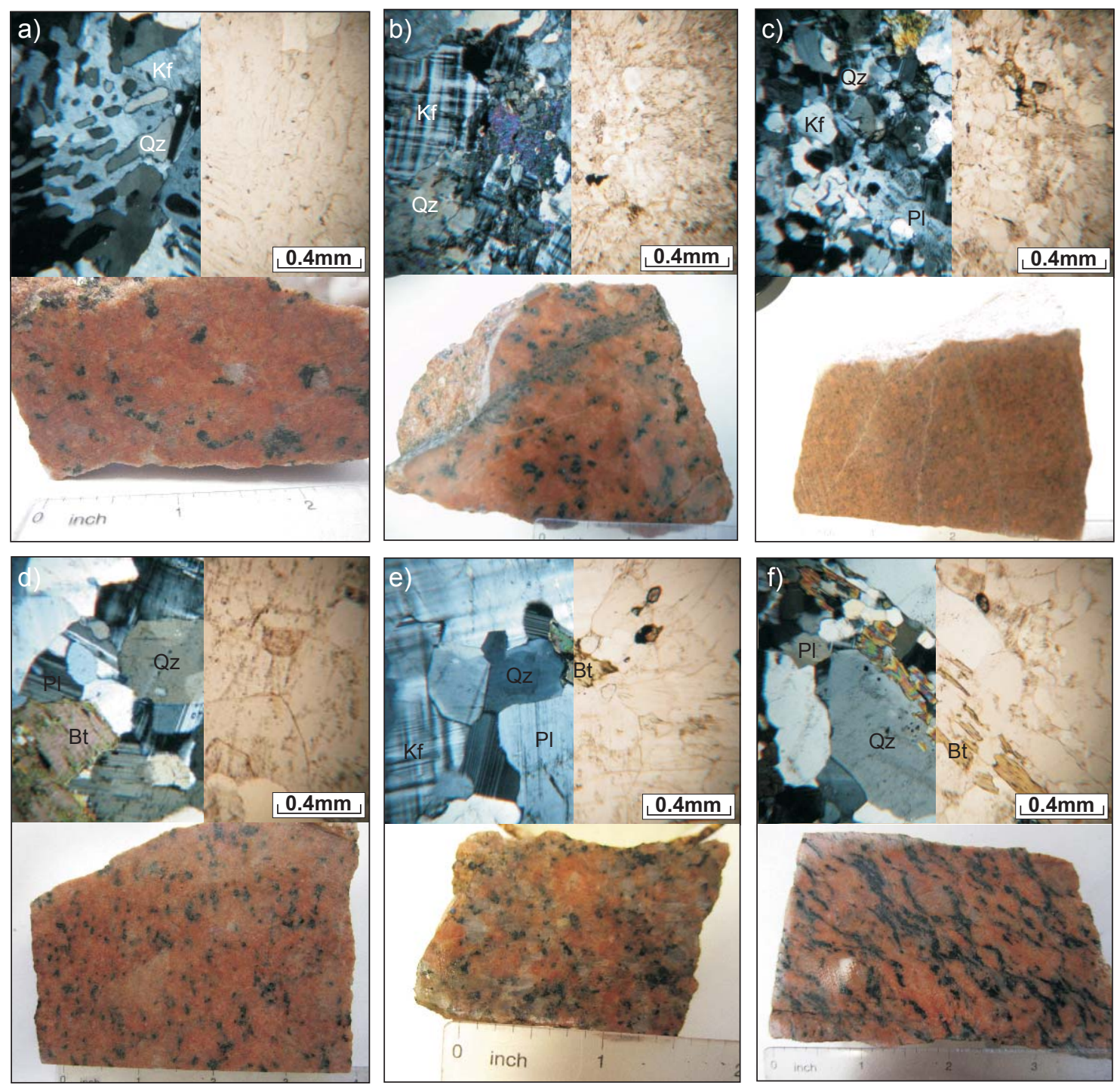

Figure 3.6: Representative photomicrographs (cross-polarised on the left, plainpolarised on the right) and corresponding sample photographs for the granitemonzogranite plutons; a) Barbers Lake monzogranite: JC-002. Coarse-grained, massive texture displaying micrographic intergrowth between K-feldspar and quartz; b). Elphin biotite-rich granite-syenite: JC-059. Massive, coarse-grained texture displaying micrographic intergrowth between K-feldspar and quartz.and serecitic alteration; c) Elphin grained granite-syenite: JC-055 Fine-grained, granular, crystalline K-feldspar, plagioclase and quartz; d) Leggat Lake alkali feldspar granite-monzogranite: JC-026. Coarse-grained, massive texture; e) McLean granite: JC-075. Coarse-grained, massive texture; f) Cranberry Lake foliated granite: $\mathrm{JC}-034$. Coarse-grained, foliated texture. $\mathrm{Kf}=\mathrm{K}$-feldspar; $\mathrm{PI}=$ plagioclase feldspar; $\mathrm{Qz}=$ quartz; $\mathrm{Bt}=$ biotite; $\mathrm{Hbl}=$ hornblende. 


\section{Chapter 4 - Geochronology}

$\mathrm{U}-\mathrm{Pb}$ zircon geochronology studies were undertaken in order to establish whether the 6 undated plutons; Skootamatta, Wolfe Lake, Rideau Lake, Leggat Lake, Elphin and Cranberry Lake were part of the Kensington-Skootamatta suite.

\subsection{Geochronology Methods}

One locale from each of the Skootamatta, Wolfe Lake, Rideau Lake, Leggat Lake, Elphin, and Cranberry Lake plutons was selected for sampling for $\mathrm{U}-\mathrm{Pb}$ zircon geochronology studies. Samples are representative of the rock-type and morphology of each pluton, and are centrally located within the pluton (figures 1.2 and 1.3). Sample preparation, chemistry and analyses were carried out at the Isotope Geochemistry and Geochronology Research Centre (IGGRC) at Carleton University. Sample preparation and chemistry was carried out using methods modified after Parrish et al. (1987) and analyses were carried out using a ThermoFinnigan Triton TI Thermal lonisation Mass Spectrometer. Treatment of analytical errors was carried out using Tripoli (Bowring 2012) and U-Pb Redux (Bowring 2013) programs.

From 5-10 kg of rock, a heavy mineral concentrate was prepared for each sample using standard crushing, grinding, Rogers ${ }^{\mathrm{TM}}$ table and heavy liquids techniques (Krogh 1982b). The highest quality, least magnetic zircons were separated from the remaining heavy minerals using a Frantz ${ }^{\mathrm{TM}}$ isodynamic separator. In separating out the least magnetic zircons, the probability of obtaining concordant grains; free of inclusions, is increased (Krogh 1982b). The 
best quality zircons were reserved for analysis; however, representative but poorer-quality grains from each sample were selected for imaging on Carleton University's Cameca Camebax MBX electron microprobe to determine whether the grains contained any inherited components or overgrowths, and to image primary zircon growth features or alteration zones. Imaging was done primarily using cathodoluminescence (CL). See figure 4.2 for scanning electron microprobe (SEM) images of zircons from each pluton. Further SEM images are shown in Appendix A - MRD311.

Zircons were hand-picked in ethanol based on their clarity with few fractures or inclusions, and the most euhedral crystal shape. See figure 4.1 for images of representative zircons from each pluton. The zircon grains were then imaged in order to better assess their quality.

Chemical abrasion or leaching techniques were used to ostensibly eliminate areas of radiation damage and $\mathrm{Pb}$ loss from the exterior of the grains as well as from fractures, dislocations, altered zones or inclusions within the grains with the objective of reducing discordance in $\mathrm{U}-\mathrm{Pb}$ results. The selected grains were annealed (for 48 hours in $1000^{\circ} \mathrm{C}$ ) and chemically abraded (leached using $\mathrm{HF}$ and $\mathrm{HNO}_{3}$ using methods modified after Mattinson (2005). Selected grains were abraded for varying lengths of time depending on their crystal quality and in order to test the optimal time to achieve concordant data. Zircon morphology descriptions and chemical abrasion times are summarised in table 4.1. See appendix A-MRD311 for dissolution chemistry and column chemistry details. 
Two fractions of zircon that had been physically abraded were analysed to compare the newer chemical leaching methods vs. the traditional air abrasion methods. Physical abrasion of zircon grains is done using compressed air and pyrite and is used to eliminate the outer areas of the zircon grains that are more susceptible to Pb-loss (Krogh 1982a).

\subsection{Age interpretations}

Data reduction, calculation of statistics and error propagation was done using the programs Tripoli (Bowring 2012) and U-Pb Redux (Bowring 2013). Data are considered to be concordant when the ${ }^{238} \mathrm{U} /{ }^{206} \mathrm{~Pb},{ }^{235} \mathrm{U} /{ }^{207} \mathrm{~Pb}$ and ${ }^{207} \mathrm{~Pb} /{ }^{206} \mathrm{~Pb}$ ages are $\leq 0.3 \%$ discordant. Errors on the ages are reported at the $2 \sigma$ level. Concordant fractions are taken to represent the age of the rock. In cases where there is systematic $\mathrm{Pb}$ loss, then the weighted mean of the ${ }^{207} \mathrm{~Pb} /{ }^{206} \mathrm{~Pb}$ ages and/or the upper intercept of three or more fractions that fall on a line of discordia may be taken to represent the age of the rock. During this project, the U-Pb geochronology lab was being brought back into production after a long period of abeyance with attendant problems in reducing blanks and refining chemistry procedures. In addition, chemical abrasion techniques were implemented for the first time. There were some analytical problems, thus not all of the analysed fractions were used in the interpretations of the pluton ages. A procedural blank was analysed with each batch of zircon fraction. The blank composition has been calculated to be ${ }^{206} \mathrm{~Pb} /{ }^{204} \mathrm{~Pb}=18.350 \pm 0.275,{ }^{207} \mathrm{~Pb} /{ }^{204} \mathrm{~Pb}$ $=15.6 \pm 0.1,{ }^{208} \mathrm{~Pb} /{ }^{204} \mathrm{~Pb}=38.08 \pm 0.38$. Fractions were excluded due to procedural errors or high blanks resulting in poor mass spectrometry data or 
excessively large errors. Fractions that are displayed on the concordia plots in figure 4.3 are shown in table 4.1, whereas rejected fractions are shown in table

4.2. The mass-spectrometry fractionation model that was used is: alpha $U=0.03$ with a $1 \sigma$ abs of 0.02 , and alpha $\mathrm{Pb}=0.170$ with a $1 \sigma$ of 0.03 . Initial $\mathrm{Pb}$ was calculated using a Stacey-Kramers model (Stacey and Kramer 1975).

\subsection{Results}

\subsubsection{Skootamatta pluton - 92RME-0402}

Sample 92RME-0402 was collected by Drs. Michael Easton and Sharon Carr in 1992. The sample was taken from the same outcrop as JC-031; along Hughes Landing Rd, 4.6 km West of Cloyne, Ontario (NAD83 321802 E, $4965569 \mathrm{~N}$ : figure 1.2a). The sample is a coarse-grained, massive, biotite-rich monzonite consisting mainly of K-feldspar, plagioclase (and perthite), minor quartz, biotite and minor hornblende.

The sample yielded a large population of excellent quality, clear, colourless to pink, prismatic, euhedral and well-faceted grains with few to a moderate amount of fractures and inclusions (figure 4.1a). SEM imaging of the grains, show homogenous zircons or oscillatory zoning typical of magmatic zircons (figure 4.2a: Corfu et al. 2003). Some grains exhibit textures in the core that may be evidence of inheritance or irregular textures that may reflect overgrowths, metamict or altered zones.

Due to the abundant excellent quality zircon grains from this sample, and the fact that it was previously dated by Carr and Easton (1995 unpublished data), 
this sample was used to test analytical methods during the reestablishment of U$\mathrm{Pb}$ geochronology at the IGGRC at Carleton University. Many fractions were analysed to determine optimal laboratory and analytical procedures. In total, 16 fractions were analysed; 7 single grain fractions, and 7 multi-grain fractions that were chemically abraded for varying lengths of time, and two fractions that were physically air abraded for 5.5 hours. The fractions were chemically abraded for varying lengths of time to determine the optimal time required to reduce discordance in the results markedly. The Skootamatta grains survived up to 54 hours with no apparent degradation in the coherence of the grain. Two physically abraded fractions were used to compare the older conventional methods to the newer chemical abrasion methods. See tables 4.1 and 4.2 for descriptions and analytical data for each fraction.

Five of the fractions yielded high quality data that are used to interpret the age of the rock (table 4.1). Analysis of multi-grain fraction I1 yielded data that is $0.28 \%$ discordant. This fraction is, therefore, interpreted to be concordant. The age of fraction I 1 is calculated to be $1086.3 \pm 0.6 \mathrm{Ma}$ by taking the weighted mean of its ${ }^{206} \mathrm{~Pb} /{ }^{238} \mathrm{U}$ and ${ }^{207} \mathrm{~Pb} /{ }^{238} \mathrm{U}$ ages (figure 4.3a). This is considered the best estimate for the age of crystallization. The age obtained in this study is within error of the $1083 \pm 3$ Ma age obtained by Carr and Easton (1995 unpublished data). Fraction $\mathrm{I} 1$ has a $\mathrm{U}$ concentration of $85 \mathrm{ppm}$ and a $\mathrm{Th} / \mathrm{U}$ ratio of 0.58 .

Analysis of fractions B3, C1, E1, and G2 yielded data that are between 0.4-1.9\% discordant and are interpreted to have undergone $\mathrm{Pb}$ loss. A regression 
of the data from these 4 fractions and concordant fraction I1 yields an upper intercept of $1088.0+2.9 /-1.5$ Ma with a mean square of the weighted deviates (MSWD) of 1.8. A weighted average of their ${ }^{207} \mathrm{~Pb} /{ }^{206} \mathrm{~Pb}$ ages is calculated to be 1087.4 \pm 1.0 Ma with an MSWD of 1.5 (table 4.1, figure 4.3a). These 4 fractions have between 45-117 ppm $U$, and Th/ $\mathrm{U}$ of 0.54-0.67.

Fractions $\mathrm{I} 2$, J1, and $\mathrm{K} 1$ were between $-7.1-5.11 \%$ discordant. Fraction $\mathrm{J} 1$ (5.11\% discordant) has $\mathrm{a}^{207} \mathrm{~Pb} /{ }^{206} \mathrm{~Pb}$ age of $1125.5 \pm 2.4 \mathrm{Ma}$ and is interpreted to have an inherited component of radiogenic $\mathrm{Pb}$ that is this age or older, as well as having undergone a component of $\mathrm{Pb}$ loss, based on the position of the error ellipse on the concordia diagram (figure 4.3a). The cause of the negative discordance in fractions 12 and K1 remains unclear. (See the geochronology summary for possible causes of negative discordance). These fractions have $U$ concentrations of 85-117 ppm and a Th/U ratio of 0.54-0.64.

Fractions $\mathrm{I} 1$ and $\mathrm{I} 2$ were physically abraded for 5.5 hours and all other fractions that were analysed were chemically leached for 8-54 hours. Fraction I1 yielded the most concordant data for the Skootamatta pluton. Furthermore, analyses of physically abraded zircons from Carr and Easton (1995 unpublished data) yielded concordant to nearly concordant analyses. For the Skootamatta pluton, it is apparent that physical abrasion was the most effective method to obtain concordant data. The zircon grains from this pluton are of excellent quality and were able to withstand leaching in hydrofluoric acid (HF) in excess of 40 hours. It is therefore possible, that leaching was having little effect on the grains unless there were fractures or inclusions. Thus, it is recommended that for big, 
robust zircons; such as those in the Skootamatta pluton, physical abrasion be used before chemical abrasion.

\subsubsection{Wolfe Lake pluton - JC-050}

Sample JC-050 was collected in the summer of 2011 from a road-cut outcrop along County Road 36, 2 km northwest of Westport, Ontario (NAD83 $386915 \mathrm{E}, 4950517 \mathrm{~N}$ : figure 1.2b). The sample is a coarse-grained biotite-rich quartz-syenite with a weak mineral foliation. It consists mainly of potassium feldspar with plagioclase (and perthite), quartz, biotite, with minor hornblende and trace apatite, zircon, titanite and pyrite.

The sample yielded a small population of moderate quality, clear, colourless to yellow, prismatic, subhedral and moderately faceted grains with few fractures and a moderate number of inclusions (figure 4.1b). The grains exhibit oscillatory zoning typical of magmatic zircons (figure 4.2b) or complex, curved zones that are of uncertain origin (Corfu et al. 2003; Hanchar and Miller 1993). There is no evidence of inherited cores; however, the irregular zonation may represent heterogeneities within the zircon such as inclusions. See table 4.1 for descriptions and analytical data for each fraction.

At the time of writing, only two fractions (A2 and B1) have been analysed; both of them are multi-grain fractions that were chemically leached for 16 and 12 hours, respectively. Analysis of fraction B1 yielded data that is $-0.18 \%$ discordant. This fraction is, therefore, considered to be concordant. The age of fraction $B 1$ is calculated to be $1075.9 \pm 1.4$ Ma by taking the weighted mean of its 
${ }^{206} \mathrm{~Pb} /{ }^{238} \mathrm{U}$ and ${ }^{207} \mathrm{~Pb} /{ }^{238} \mathrm{U}$ ages (figure $4.3 b$ ). This is considered the best estimate for the age of crystallization of the Wolfe Lake pluton. Fraction B1 has a $U$ concentration of $82 \mathrm{ppm}$ and a Th/U ration of 0.53 .

Fraction A2 yielded nearly concordant data (i.e. $0.8 \%$ discordant) with a ${ }^{207} \mathrm{~Pb} /{ }^{206} \mathrm{~Pb}$ age of $1075.0 \pm 10 \mathrm{Ma}$ (table 4.1, figure $4.3 b$ ) and falls within error of concordant fraction $\mathrm{C} 1$. Fraction $\mathrm{A} 2$ has a $\mathrm{U}$ concentration of $54 \mathrm{ppm}$, a Th/U ratio of 0.49 . The discordance is interpreted to have been caused by minor $\mathrm{Pb}$ loss. In order to finalise the age determination, an additional one or two fractions will be analysed.

\subsubsection{Rideau Lake pluton - JC-070}

Sample JC-070 was collected from a road-cut outcrop along County Road 14, 700 m north-northwest of Narrows Lock (NAD83 397084E, 4951588N): figure 1.2b). The sample is a medium-grained, massive, biotite-rich quartz monzonite. It consists mainly of potassium feldspar with plagioclase (and perthite), minor quartz, biotite and hornblende and trace apatite, zircon, garnet, pyrite, and chalcopyrite.

The sample yielded a small population of moderate to good quality, clear, colourless, prismatic, subhedral, moderately- to well-faceted grains with few fractures or inclusions (figure 4.1c). The grains either exhibit oscillatory or banded zoning; both of which are typical of rapid growth in magmatic zircons (figure 4.2c: Corfu et al. 2003), however, there is also evidence in some grains of 
possible metamictization or overgrowths. There is no evidence of inherited cores. See table 4.1 for descriptions and analytical data for each fraction.

At the time of writing, 3 fractions have been analysed; 2 single grain fractions (C1, D1) that were chemically leached for 12 hours and 1 multi-grain fraction (B1) that was chemically leached for 16 hours. Single-grain fraction C1 yielded data that is $-0.15 \%$ discordant. The fraction is, therefore, considered to be concordant. The age of fraction $\mathrm{C} 1$ is calculated to be $1072.4 \pm 1.0 \mathrm{Ma}$ by taking the weighted mean of its ${ }^{206} \mathrm{~Pb} /{ }^{238} \mathrm{U}$ and ${ }^{207} \mathrm{~Pb} /{ }^{238} \mathrm{U}$ ages (table 4.1, figure 4.3c). This is considered the best estimate for the age of crystallization of the Rideau Lake pluton. Fraction $\mathrm{C} 1$ has a $\mathrm{U}$ concentration of $75 \mathrm{ppm}$ and a Th/U ratio of 0.63 .

Multigrain fractions B1 and D1 were 1.29 and $2.03 \%$ discordant and have ${ }^{207} \mathrm{~Pb} /{ }^{206} \mathrm{~Pb}$ ages of $1090.9 \pm 3.4 \mathrm{Ma}$ and $1084.9 \pm 2.2 \mathrm{Ma}$, respectively. These fractions are interpreted to have an inherited component of radiogenic $\mathrm{Pb}$ that is this age or older, as well as having undergone Pb-loss. These fractions have $U$ concentrations of $143-344 \mathrm{ppm}$ and $\mathrm{Th} / \mathrm{U}$ ratios of $0.46-0.54$. In order to finalise the age determination, two additional fractions will be analysed with the goal of obtaining concordant analysis.

\subsubsection{Leggat Lake pluton - JC-063}

Sample JC-063 was collected in the summer of 2011 from a road-cut outcrop along Leggat Lake Rd, $3 \mathrm{~km}$ east-northeast of Long Lake, Ontario (NAD83 363103E, 4951414N: figure 1.3c). The sample is a medium-grained, 
massive, alkali feldspar granite to leucogranite with a granular to sugary texture. It consists of potassium feldspar, plagioclase (and perthite), and quartz with minor biotite, and trace amounts of zircon, apatite, garnet, chalcopyrite, pyrite, and magnetite.

The sample yielded a small population of poor to moderate quality, clear to cloudy, colourless to yellow-orange, prismatic, subhedral to euhedral, moderately- to well-faceted grains with few inclusions or fractures (figure 4.1e). The grains exhibit either a homogeneous texture or oscillatory zoning typical of magmatic zircons (figure 4.2e: Corfu et al. 2003). There is no evidence of inherited cores; however, some grains may show evidence of overgrowths. See table 4.1 for descriptions and analytical data for each fraction.

In total 4 fractions were analysed; 1 single grain fraction (C2), and 3 multigrain fractions (A2, B1, C1) that were chemically leached for 12 to 16 hours. Analysis of 2 fractions (A2, C2) yielded concordant data within error of each other. Fraction C2 yielded data that is $0.06 \%$ discordant. The fraction is, therefore, considered to be concordant and had the smallest associated error ellipse. The age of fraction C2 is calculated to be $1077.0 \pm 0.7$ Ma by taking the weighted mean of its ${ }^{206} \mathrm{~Pb} /{ }^{238} \mathrm{U}$ and ${ }^{207} \mathrm{~Pb} /{ }^{238} \mathrm{U}$ ages. This is considered the best estimate for the crystallization age of the Leggat Lake pluton. Analysis of fraction A2 also yielded concordant data $(0.02 \%)$; however, it had a greater associated error. The weighted mean of the ${ }^{206} \mathrm{~Pb} /{ }^{238} \mathrm{U}$ and ${ }^{207} \mathrm{~Pb} /{ }^{235} \mathrm{U}$ ages of fraction $\mathrm{A} 2$ is calculated to be $1073.7 \pm 7.3 \mathrm{Ma}$. This is within error of the age calculated using 
the data from fraction $\mathrm{C} 2$. The $U$ concentrations of fractions $\mathrm{A} 2$ and $\mathrm{C} 2$ are 340.96-445.4 ppm and the Th/U ratios are $0.40-0.57$.

Fraction $\mathrm{C} 1$ is $5.65 \%$ discordant and is interpreted to have undergone $\mathrm{Pb}$ loss. The ${ }^{207} \mathrm{~Pb} /{ }^{206} \mathrm{~Pb}$ age of fraction $\mathrm{C} 1$ is $1084.1 \pm 1.9 \mathrm{Ma}$. A regression of the data from fractions A2, C1, and C2 yields an upper intercept of 1077.1 +1.5/-1.4 Ma with an MSWD of 0.85 . A weighted average of the ${ }^{207} \mathrm{~Pb} /{ }^{206} \mathrm{~Pb}$ ages from these fractions is calculated to be $1079.8 \pm 1.1$ Ma with an MSWD of 17 (table 4.1, Figure 4.3d). Fraction $\mathrm{C} 1$ has a $U$ concentration of $217 \mathrm{ppm}$ and a Th/U ratio of 0.59 . Fraction $\mathrm{B} 1$ was negatively discordant and has a $U$ concentration of 186 $\mathrm{ppm}$ and $\mathrm{a} \mathrm{Th} / \mathrm{U}$ ratio of 0.50 . The cause of the negative discordance is uncertain at the present time (See the geochronology summary for possible causes of negative discordance). No further analysis of this pluton is required.

\subsubsection{Elphin pluton - JC-059}

Sample JC-059 was collected in the summer of 2012 from a road-cut outcrop along Concession Road 4, 1.4 km east-southeast of Elphin, Ontario (NAD83 371169E, 4975085N: figure 1.3b). The sample is a coarse-grained, massive biotite-rich quartz syenite. It consists mainly of potassium feldspar with quartz and biotite, minor plagioclase and pyrite and trace apatite, zircon, chalcopyrite, and magnetite.

The sample yielded a small population of moderate quality, clear, colourless to yellow, prismatic, subhedral, moderately faceted grains with few inclusions and few to a moderate number of fractures (figure 4.1d). The grains 
exhibit either complex, curved zones that are of unknown origin, or oscillatory zoning typical of magmatic zircons (figure 4.2d: Corfu et al. 2003; Hanchar and Miller 1993). There is no evidence of inherited cores; however, the unexplained zircon zoning may be a source of inheritance. See table 4.1 for descriptions and analytical data for each fraction.

In total 6 fractions were analysed; 4 single grain fractions (B1, B2, B3, B4), 1 multi-grain fraction (A1), that was chemically leached for 16 hours and 1 multigrain fraction (C1) that was leached for 12 hours. Fractions B1, B3, B4 and C1 ranged from $0.39-5.35 \%$ discordant. A regression of the data yielded a discordia line with an upper intercept of $1178.4+2.5 /-2.3 \mathrm{Ma}$ and an MSWD of 20. A weighted average of ${ }^{206} \mathrm{~Pb} /{ }^{207} \mathrm{~Pb}$ ages is calculated to be $1168.33 \pm 0.85$ with an MSWD of 51 (table 4.1, figure 4.3e). The upper intercept age is taken as the best estimate for the crystallization age of the Elphin pluton. Fractions B1, B3 and B4 had $U$ concentrations of $75-260$ and $T h / U$ ratios of $0.34-0.89$.

Fractions A1 and B2 were between $6.78 \%$ and $11.01 \%$ discordant and have ${ }^{207} \mathrm{~Pb} /{ }^{206} \mathrm{~Pb}$ ages of $1227.3 \pm 5.7 \mathrm{Ma}$ and $1218.3 \pm 5.7 \mathrm{Ma}$, respectively. These fractions are interpreted to have an inherited component of radiogenic $\mathrm{Pb}$ that is this age or older, as well as having undergone $\mathrm{Pb}$-loss. The $\mathrm{U}$ concentration of these fractions is $103-245 \mathrm{ppm}$ and their $\mathrm{Th} / \mathrm{U}$ ratio is $0.95-1.04$. Analysis of additional one or two fractions is required to constrain the age of this pluton with greater confidence. 


\subsubsection{Cranberry Lake pluton - JC-066}

Sample JC-066 was collected in the summer of 2011 from a road-cut outcrop along Mountain Rd, 4.3 km northeast of Bellrock, Ontario (NAD83 $346651 \mathrm{E}, 4934172 \mathrm{~N}$ : figure 1.3a). The sample is a medium-grained, massive biotite-rich granite with a weak to moderate mineral foliation. It consists mainly of potassium feldspar, plagioclase, and quartz, with minor biotite and hornblende and trace zircon and apatite.

The sample yielded a moderate population of good quality clear, colourless, prismatic, euhedral, moderately- to well-faceted grains with few fractures or inclusions (figure 4.1f). The grains exhibit oscillatory zoning typical of magmatic zircons (figure 4.2f: Corfu et al. 2003). There is no evidence of inherited cores; however, some grains may have evidence of overgrowths that could cause inheritance. See table 4.1 for descriptions and analytical data for each fraction.

In total 4 fractions were analysed; 1 single-grain fraction (D1) and 3 multigrain fractions (A2, B1, C1) that were chemically leached for 12-22.5 hours. Analysis of mutli-grain fraction A2 yielded data that was $0.10 \%$ discordant. Fraction A2 is, therefore, concordant. The age of fraction A2 is calculated to be $1157.2 \pm 1.4 \mathrm{Ma}$ by taking the weighted mean of its ${ }^{206} \mathrm{~Pb} /{ }^{238} \mathrm{U}$ and ${ }^{207} \mathrm{~Pb} /{ }^{238} \mathrm{U}$ ages. This is considered as the best estimate for the crystallization age of the Cranberry Lake pluton. The $U$ concentration of fraction $A 2$ is $218 \mathrm{ppm}$ and the $\mathrm{Th} / \mathrm{U}$ ratio is 0.38 . 
Analysis of fraction D1 yielded data that was $5.05 \%$ discordant (Table 4.1, Figure 4.3f) and has a ${ }^{207} \mathrm{~Pb} /{ }^{206} \mathrm{~Pb}$ age of $1176.8 \pm 2.0 \mathrm{Ma}$. The discordance is interpreted to have been caused by Pb-loss. This is not within error; by 16 million years, of the age calculated for concordant fraction $A 2$. The $U$ concentration of fraction $\mathrm{D} 1$ is $113 \mathrm{ppm}$ and the $\mathrm{Th} / \mathrm{U}$ is 0.98 . Fractions $\mathrm{B} 1$ and $\mathrm{C} 1$ were negatively discordant. The cause of the negative discordance remains unclear. (See the geochronology summary for possible causes of negative discordance). Additional one or two fractions will be analysed to further constrain the age with greater confidence.

\subsection{Summary of Geochronology Results}

The dated samples are representative of the plutons and the zircons are indeed igneous; therefore, the ages are taken to represent the crystallization ages of the respective plutons. Their crystallization ages are summarized in table

\section{3.}

There appears to be no relationship between the $U$ concentration, or the $\mathrm{Th} / \mathrm{U}$ ratios of the fractions and their degree of discordance. The cause of the negative discordance observed in some of the analyses is unclear, however, some of the reported causes may include

- ${ }^{230} \mathrm{Th}$ disequilibria: decays to ${ }^{206} \mathrm{~Pb}$, thus causing excess ${ }^{206} \mathrm{~Pb}$ in the analysis (Schoene and Bowring 2006).

- Excess ${ }^{230}$ Th may be from Th incorporated in the zircon structure or into inclusions (Schoene and Bowring 2006). 
- Excess ${ }^{207} \mathrm{~Pb}$ may arise from the decay of ${ }^{231} \mathrm{~Pa}$, however, this is rare (Schoene and Bowring 2006 and references therein).

- Calibration of $\mathrm{U} / \mathrm{Pb}$ ratios (as stated by van Breemen et al. 2005)

The Skootamatta, Wolfe Lake, Rideau Lake and Leggat Lake plutons have crystallization ages consistent with the age range of the KensingtonSkootamatta suite, whereas the Elphin and Cranberry Lake plutons have crystallization ages that are notably older than the Kensington-Skootamatta suite, but which are consistent with the age range of the Frontenac intrusive suite. 


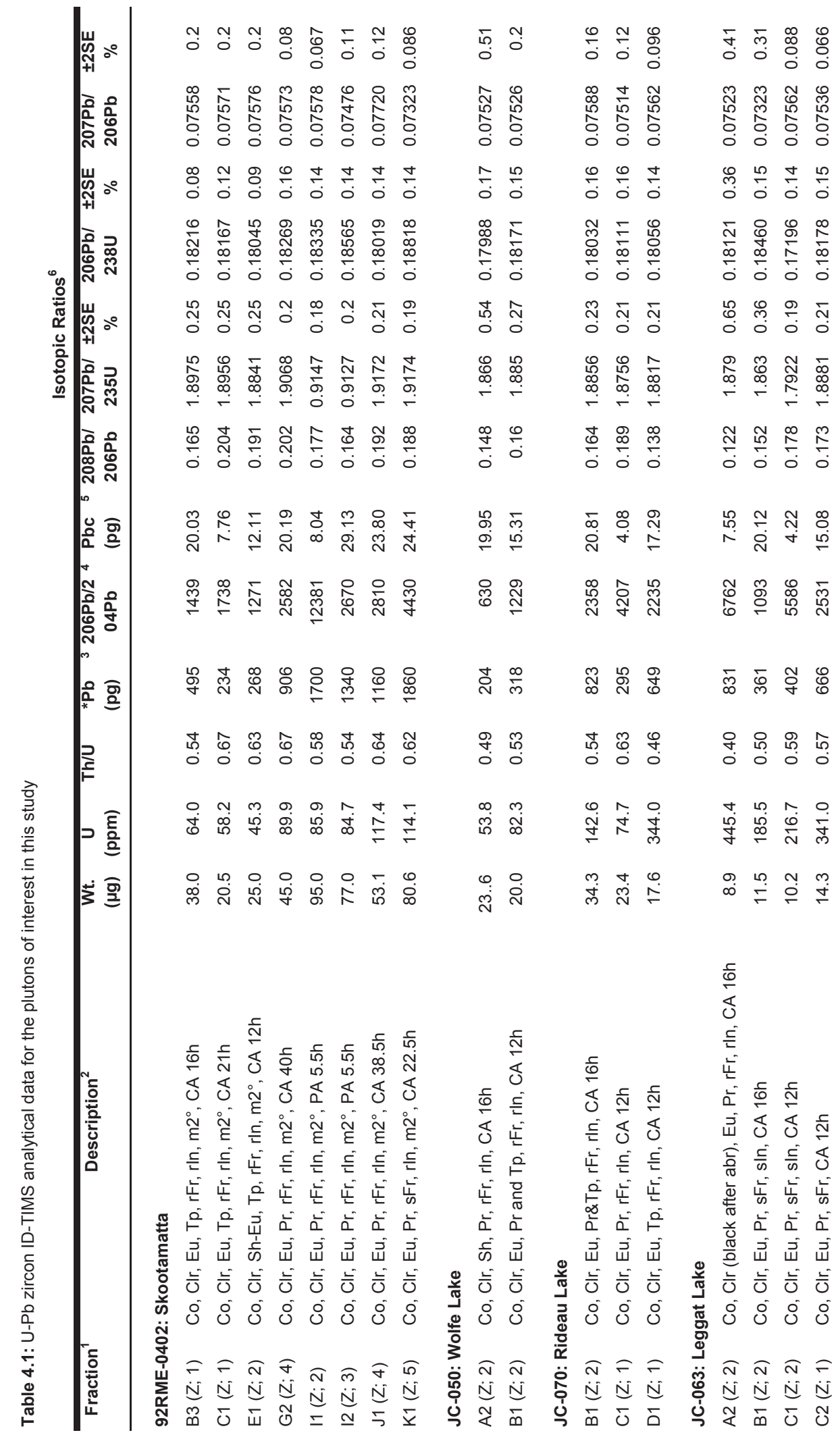




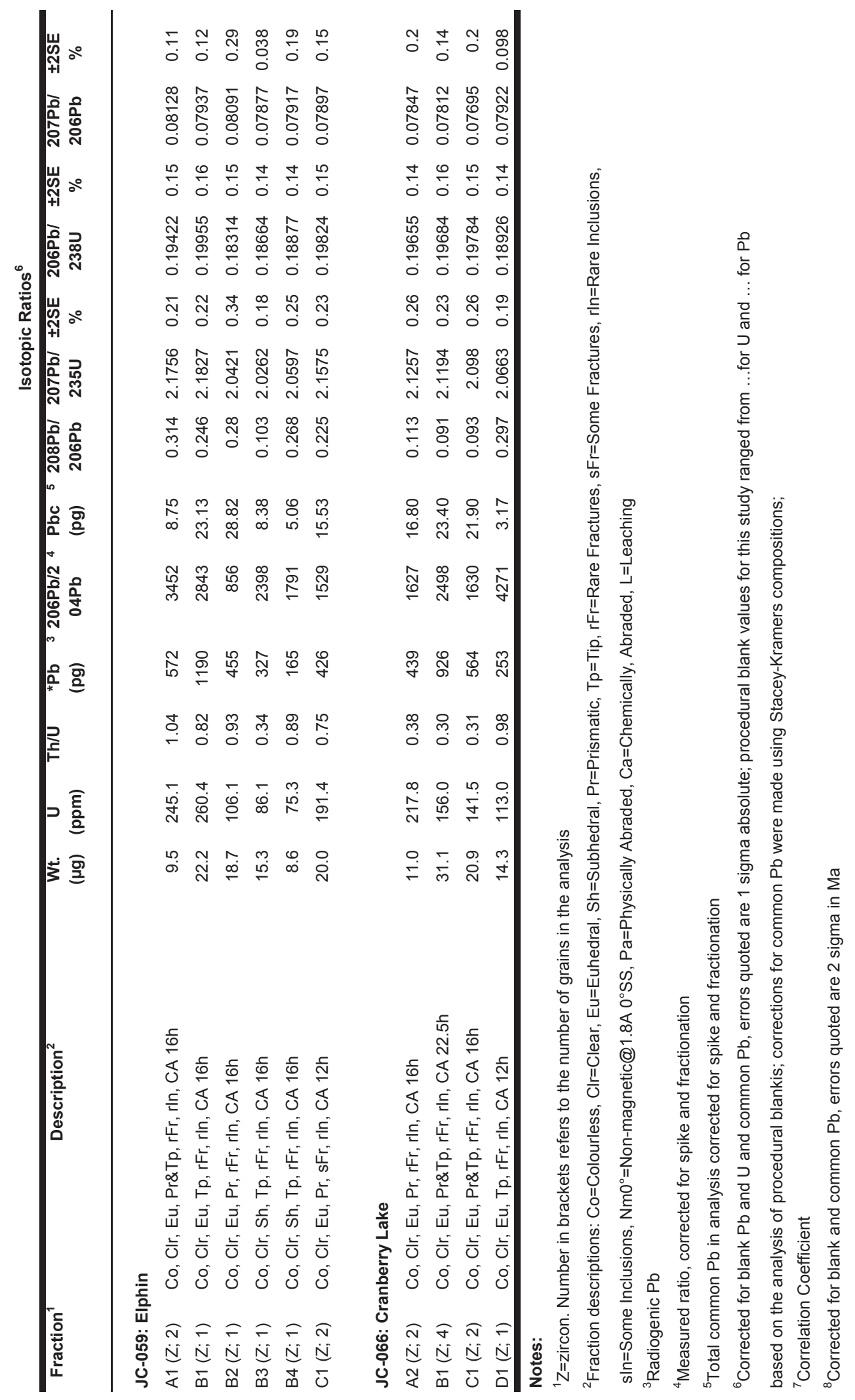




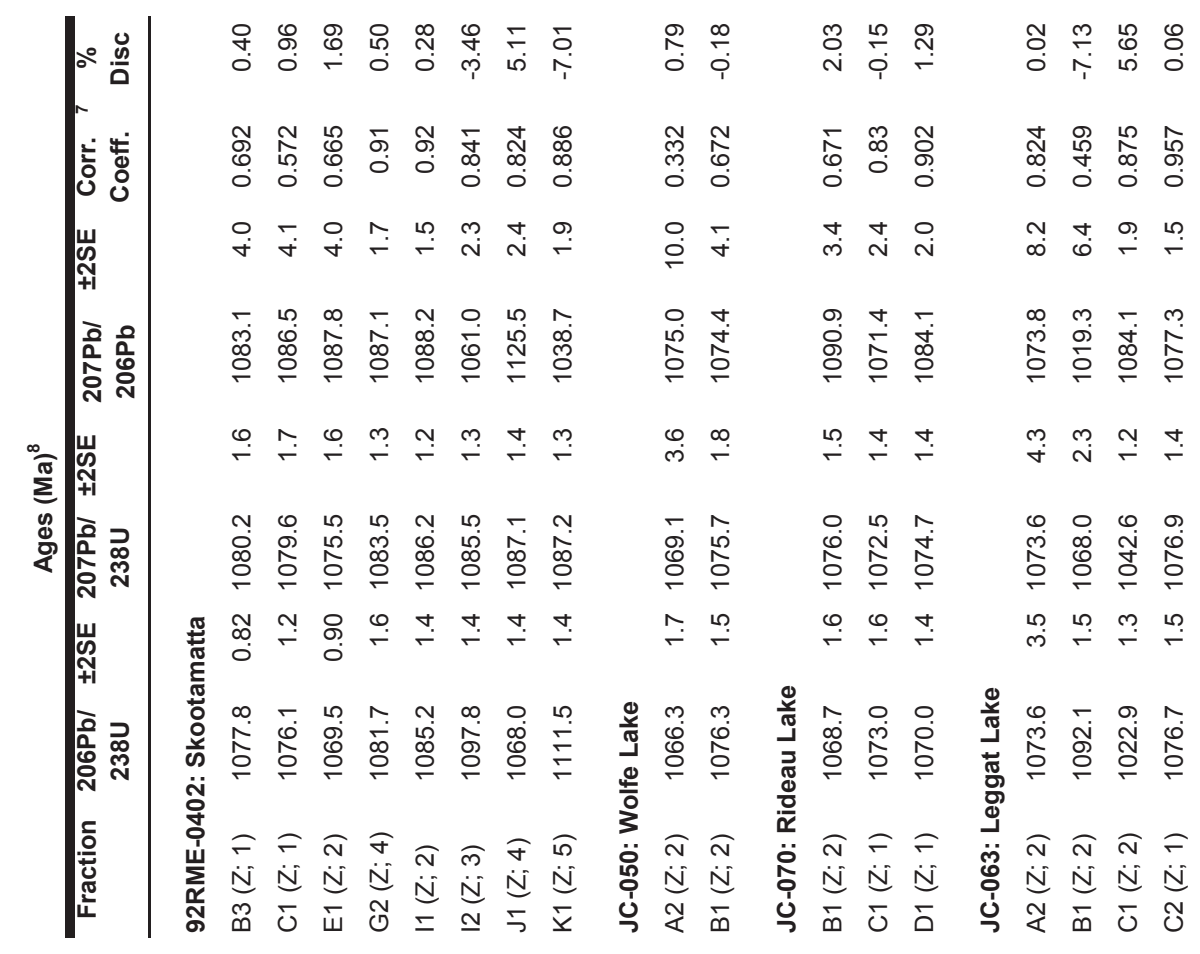




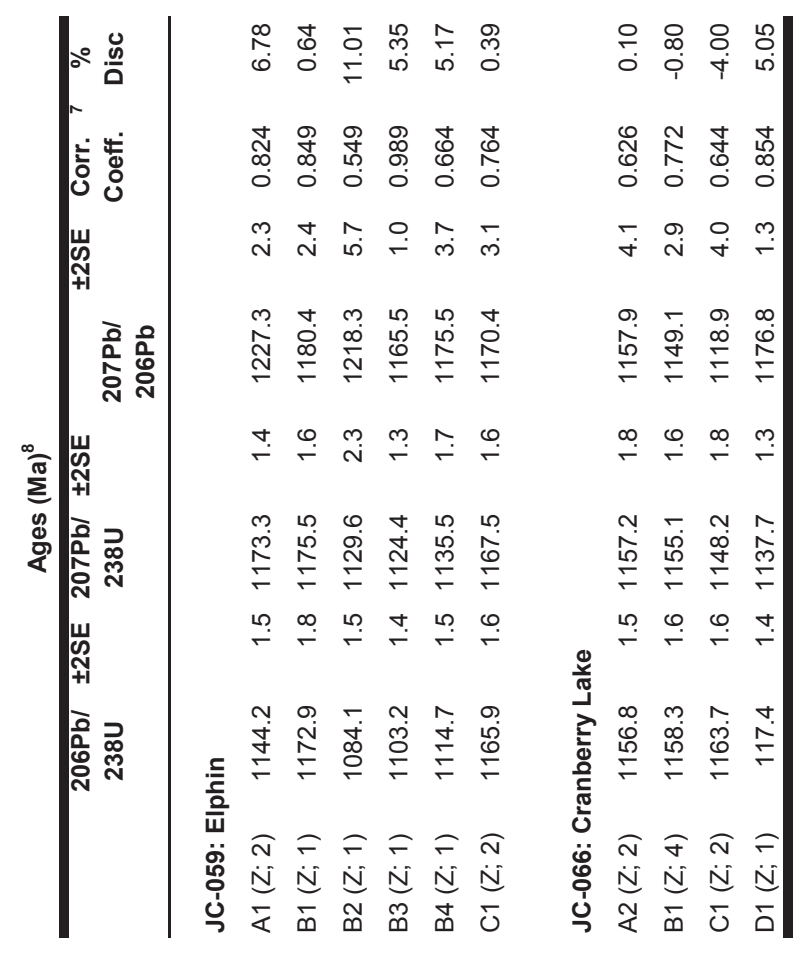




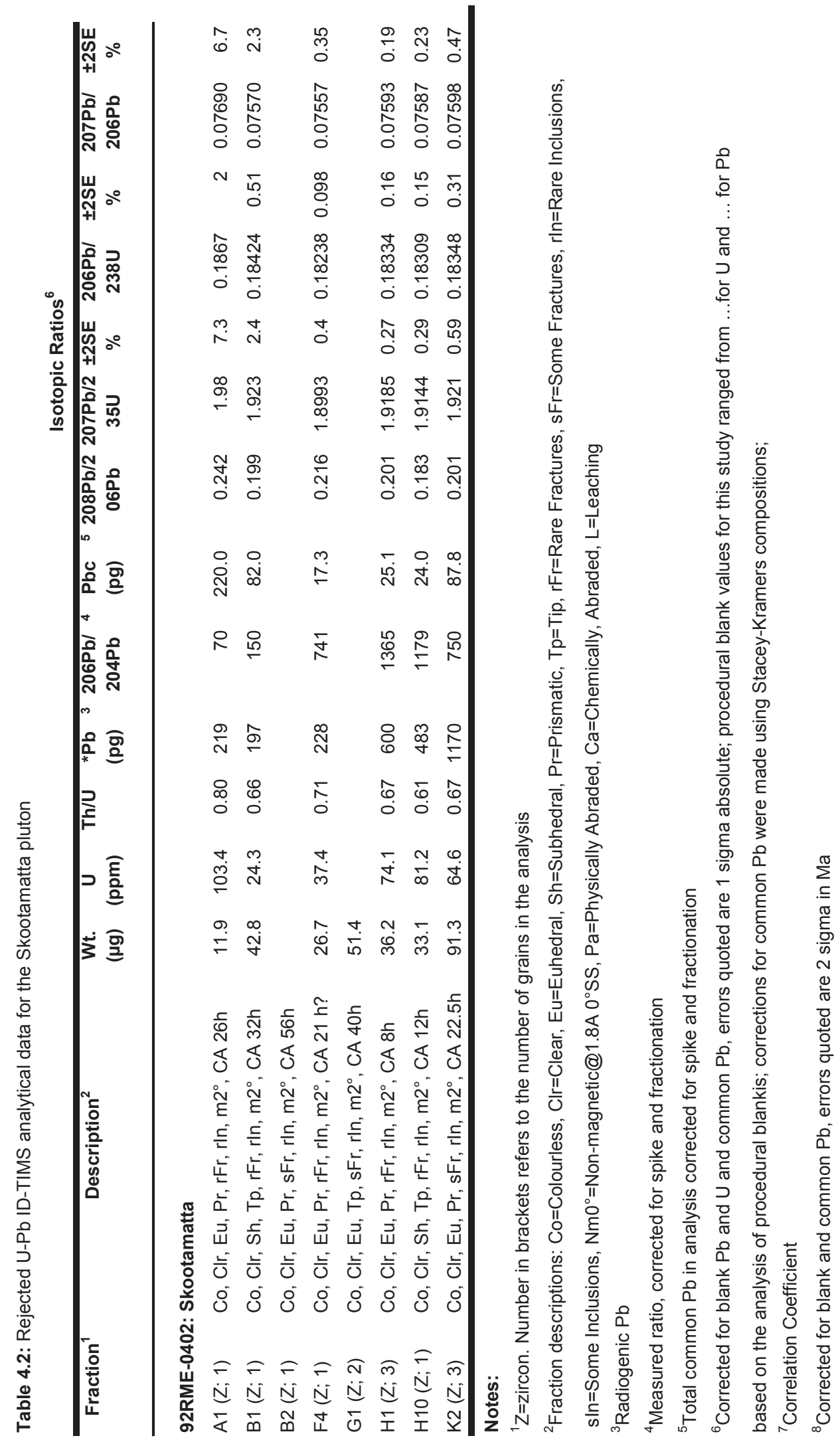




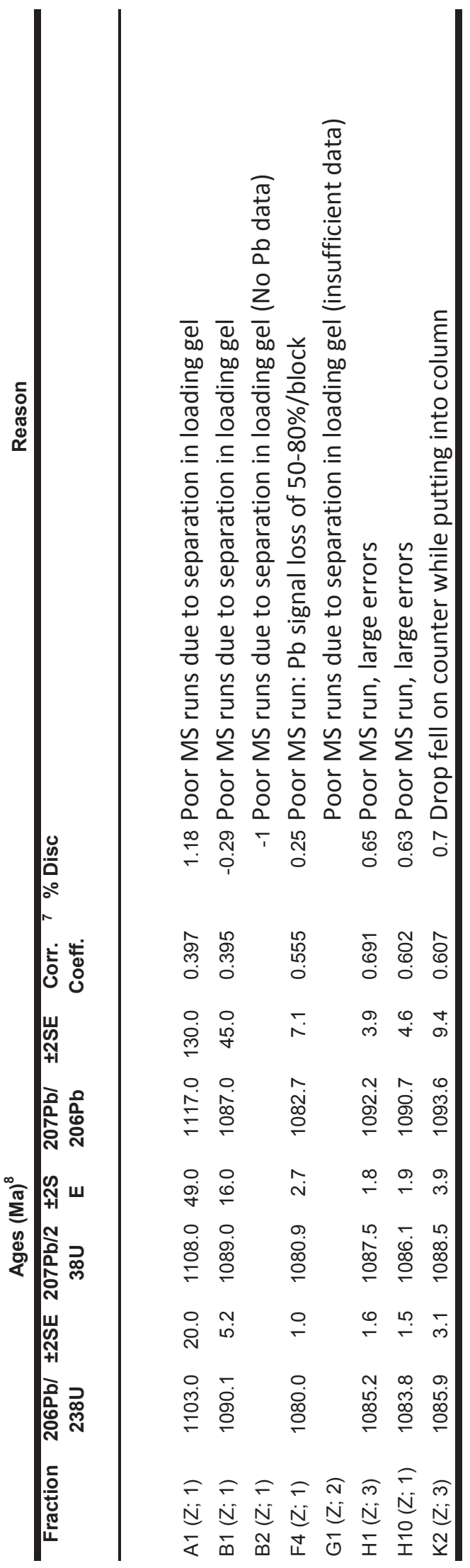


Table 4.3: U-Pb zircon ID-TIMS results summary.

\begin{tabular}{lll}
\hline Pluton & Rock Type & Emplacement Age (Ma) \\
\hline Skootamatta & bt-rich monzonite & $1086.3 \pm 0.6$ \\
Wolfe Lake & bt-rich qz-syenite & $1075.9 \pm 1.4$ \\
Rideau Lake & bt-rich qz-monzonite & $1072.4 \pm 1.0$ \\
Leggat Lake & alkali feldspar granite & $1077.0 \pm 0.7$ \\
Elphin & bt-rich syenite & $1178.4+2.5 /-2.3$ \\
Cranberry Lake & bt-rich granite & $1157.2 \pm 1.4$
\end{tabular}




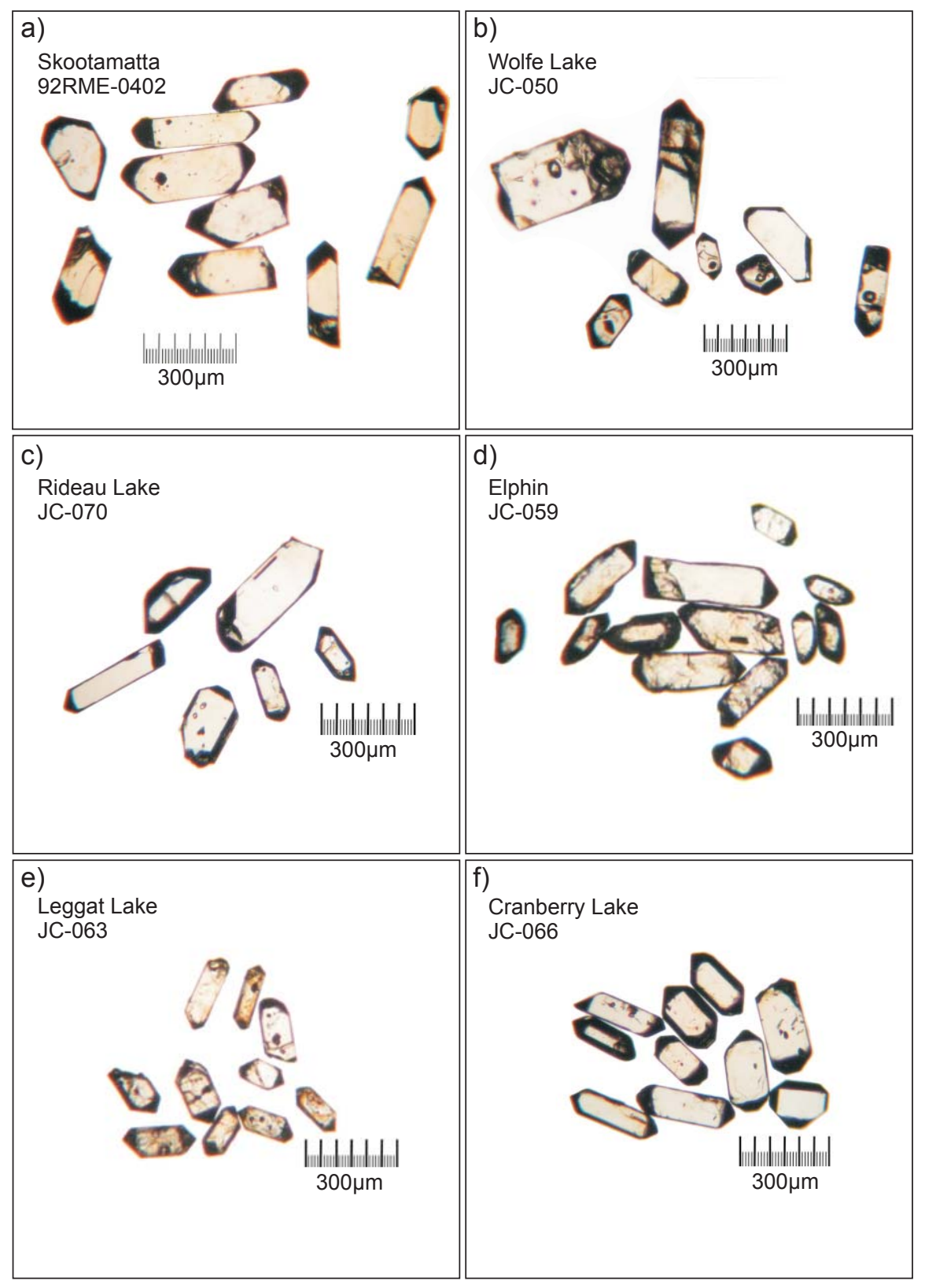

Figure 4.1: Representative zircon grains from plutons selected for U-Pb Isotope Dilution - Thermal lonisation Mass Spectrometry (ID-TIMS) geochronology studies. a) Skootamatta pluton: 92RME-0402; b) Wolfe Lake pluton: JC-050; c) Rideau Lake pluton: JC-070; d) Elphin pluton: JC-059; e) Leggat Lake pluton: JC-063; f) Cranberry Lake pluton: JC-066. 

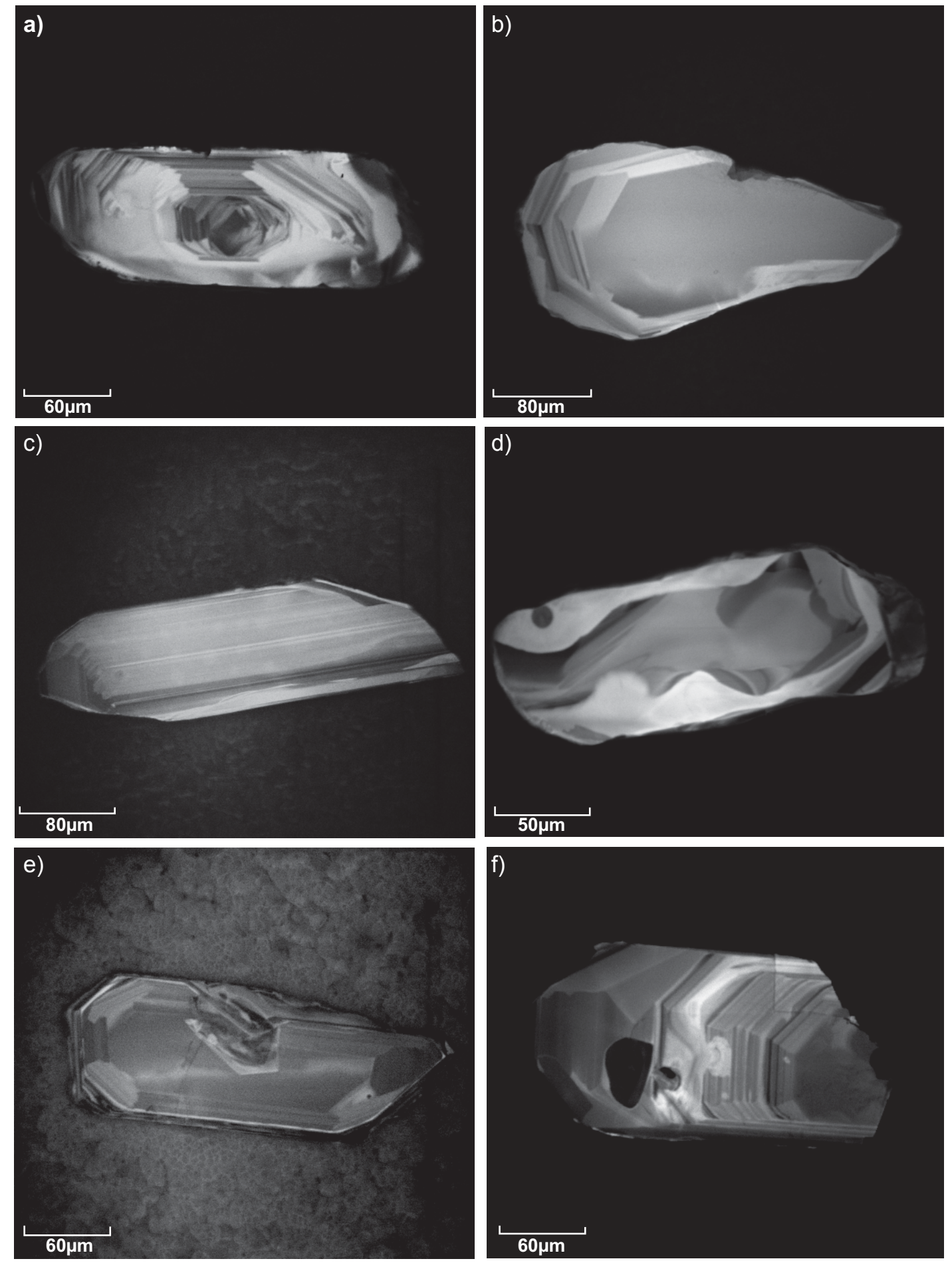

Figure 4.2: Scanning electron microscope images of representative single grains from the plutons of interest in this study. a) Skootamatta pluton: 92RME-0402; b) Wolfe Lake pluton: JC-050; c) Rideau Lake pluton: JC-070; d) Elphin pluton: JC059; e) Leggat Lake pluton: JC-063; f) Cranberry Lake pluton: JC-066. 

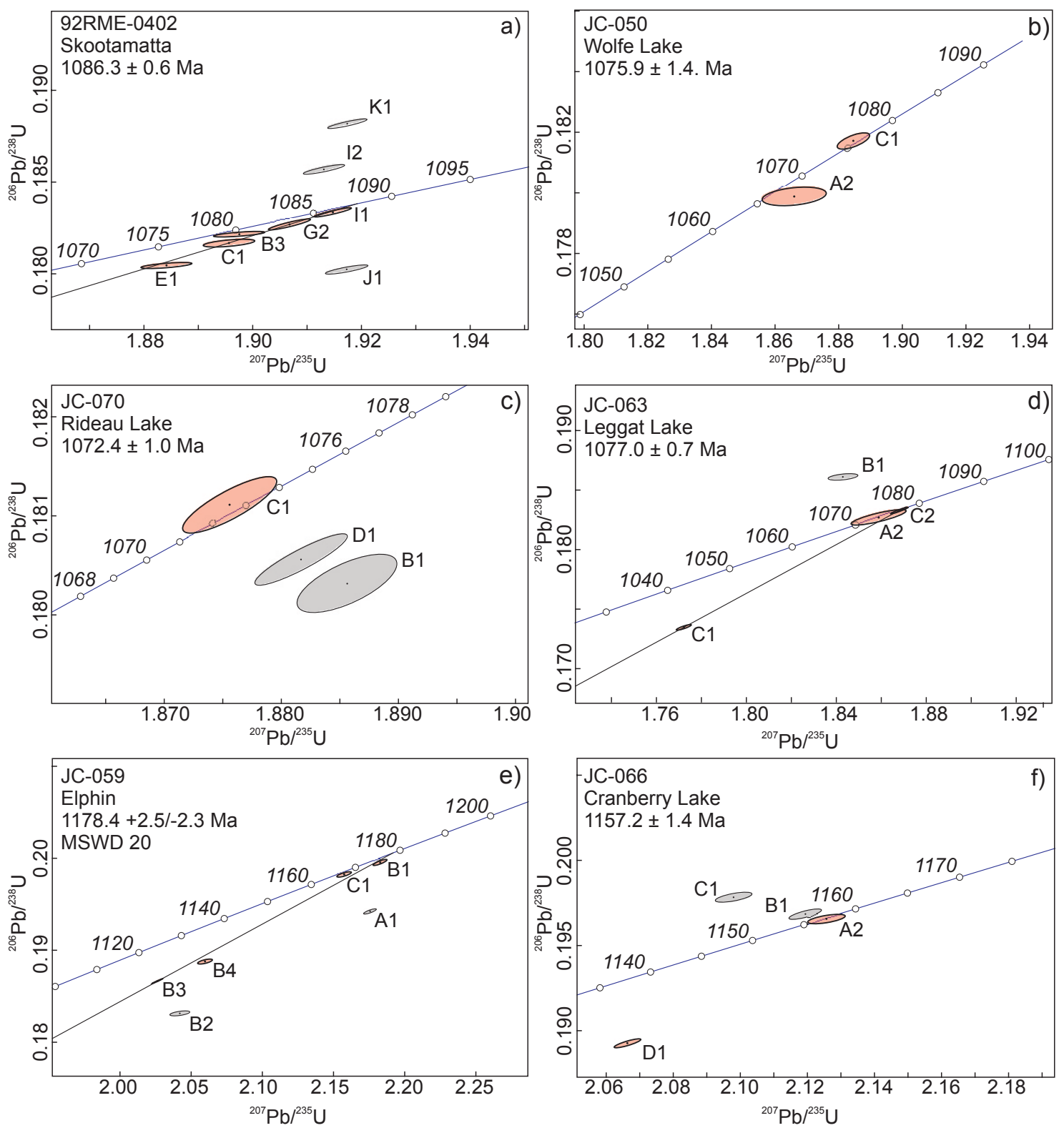

Figure 4.3: Concordia diagrams showing U-Pb geochronology results of ID-TIMS studies of zircons for the plutons of interest in this study. Pink elipses represent fractions that are used in the age calculation. a) Skootamatta pluton (92RME0402) is interpreted to have a crystallization age of $1086.3 \pm 0.6 \mathrm{Ma}$. b) Wolfe Lake pluton (JC-050) is interpreted to have a crystallization age of $1075.9 \pm 1.4 \mathrm{Ma}$. C) Rideau Lake pluton (JC-070) is interpreted to have a crystallization age of 1072.4 $\pm 1.0 \mathrm{Ma}$. d) Leggat Lake pluton (JC-063) is interpreted to have a crystallization age of $1077.0 \pm 0.7 \mathrm{Ma}$. e) Elphin pluton (JC-059) is interpreted to have a crystallization age of $1182+2.5 /-2.3 \mathrm{Ma}$. f) Cranberry Lake pluton (JC-066) is interpreted to have a crystallization age of $1157.2 \pm 1.4 \mathrm{Ma}$. See text for interpretations. 


\section{Chapter 5 - Discussion}

\subsection{The Kensington-Skootamatta suite}

The crystallization ages of the Skootamatta, Westport area, Barber's Lake, McLean and Leggat Lake plutons (Cutts, Chapter 4.4) are consistent with the previously established age range of ca. 1090-1060 Ma for the Kensington-Skootamatta suite (table 1.2, 5.1; Corriveau et al. 1990; Easton 1992). Furthermore, the geochemistry of the syenite-monzonite plutons is consistent with that of the Kensington-Skootamatta suite plutons studied by Corriveau et al. (1990) and shown in figure 3.2a-d. It is, therefore, proposed that these seven plutons are all part of the Kensington-Skootamatta suite.

The emplacement ages of the Cranberry Lake and Elphin plutons suggest that they are not part of the Kensington-Skootamatta suite. Rather, the emplacement ages of the Cranberry Lake and Elphin plutons are consistent with the ca. 1175-1150 Ma Frontenac intrusive suite (Corfu and Easton 1997). The following discussion will focus on the Kensington-Skootamatta suite plutons.

\subsubsection{Comparison of syenite-monzonite and granite-monzogranite suites}

The petrography, geochemistry, and geochronology data in this study distinguish a slightly older ca. 1086-1072 Ma syenite-monzonite and a slightly younger ca. 10771066 Ma granite-monzogranite suite within the Kensington-Skootamatta suite. The seven plutons in this study that are part of the Kensington-Skootamatta suite can be separated into two principal groups on the basis of their rock-type, geochemistry and age; as was suggested by Easton (2008). The Skootamatta, Wolfe Lake, Foley Mountain and Rideau Lake plutons are part of an older ca. 1086-1072 Ma syenitemonzonite suite and the Leggat Lake, McLean and Barber's Lake plutons are part of a 
ca. 1077-1066 Ma granite-monzogranite suite. These ages are consistent with other Kensington-Skootamatta suite plutons in Ontario (table 5.1). The two suites cannot be distinguished on age alone as there is some overlap; the Leggat Lake pluton is slightly older than the other granite-monzogranite plutons and the Rideau Lake pluton is slightly younger than the other syenite-monzonite plutons. Thus the geochemistry is key in the distinction between the two suites.

The granite-monzogranite plutons have higher $\mathrm{SiO}_{2}$ contents and lower abundances in all other major elements than the syenite-monzonite plutons. Despite these differences in major element abundance (figure 3.2 a-e; Table 2,), the two groups have similar geochemical profiles on normalised multi-element plots (figure $3.3 a, b, e$, f), however the anomalies are more pronounced in the granite-monzogranite group; particularly in the Barber's Lake pluton. Within the Westport area plutons, the Wolfe Lake pluton has a consistent multi-element profile, whereas the Foley Mountain and Rideau Lake plutons show two groups; one more enriched in HREEs and the other with lower HREE abundances resulting in a steeper curve (figure 3.3a). As expected, the syenite-monzonite plutons plot similarly on the rock discrimination diagrams in figure 3.2 to those syenites-monzonites studied by Corriveau et al. (1990). In contrast, the granites plot in a slightly lower $\mathrm{K}_{2} \mathrm{O}$ field (figure $3.2 b$ ), are more aluminum-rich (figure 3.2c), less alkaline (figure 3.2d), and more uniformly ferroan (figure 3.2e). The Barber's Lake data set is unique in that it is consistently peraluminous and alkali-calcic (figure 3.2c, d). In general, Skootamatta data plot similarly to those of the Westport area plutons, however, on the extended normalised multi-element plots, they have steeper 
profiles (lower HREE; figure 3.3a,e) and they plot in the VAG field on the Pearce et al. (1984) tectonic discrimination diagram as opposed to the WPG field (figure 3.4a).

The $\mathrm{Sm} / \mathrm{Nd}$ isotopic data for the two suites are similarly depleted $(\varepsilon \mathrm{Nd} \sim 2-4.5$ :

figure 3.5); however, there are some more 'contaminated' samples within the Foley Mountain pluton (JC-045: $\varepsilon N d-0.39$ ) and the Barber's Lake pluton (JC-001: $\varepsilon N d-6.39$ ).

\subsection{Tectonic classification and melt origin of the Kensington-Skootamatta suite}

\subsubsection{Tectonic classification}

The nature of post-orogenic magmatic suites was investigated by Bonin et al. (1998) who outlined several characteristics for rocks typical of this tectonic environment: (i) they are located in a linear belt parallel to major terrane boundary-related thrust and shear zones in a transtensional regime (ie. figure 1.1); (ii) they are felsic, and dominated by syenogranites and alkali feldspar granite rock-types; (iii) zircon morphologies are consistent with alkali-rich magmas (See figure 4.1; Pupin 1980); (iv) major and trace element whole-rock chemistry is typical of A-type and within-plate granites (figure 3.4: Pearce et al. 1984; Whalen et al. 1987). All of these characteristics are satisfied by the data characterizing the plutons of this study. It should be noted, however, that A-type and/or post-orogenic terminology has historically been used primarily for peralkaline plutonic rocks (cf. Barbarin 1990 and references therein); thus, as the plutons of interest are peraluminous to metaluminous, comparisons with present day proxies are difficult.

The tectonic discrimination diagrams in figure 3.4 indicate that, in general, the geochemistry of the plutons is consistent with those found in an intraplate, postorogenic-anorogenic tectonic setting despite their being emplaced during a main constructional period of Himalayan-scale orogenesis. The undeformed and 
unmetamorphosed nature of the plutons could be consistent with anorogenic emplacement; however, current Grenville models (Rivers 2012) suggesting that there was limited metamorphism or deformation in the superstructure of the orogen may also explain these features.

The Kensington-Skootamatta plutons all retain a weak subduction signature (minor $\mathrm{Nb}$ depletion) and significant Ti depletion, LREE enrichment (figure 3.3a,b: Rollinson 1993) and the Skootamatta intrusion plots in the volcanic arc granite fields in figure 3.4a. These geochemical characteristics were attributed to an active subduction zone by Corriveau et al. (1990); however, it is believed that active subduction had ceased with the closure of the ocean basin separating Laurentia and the Composite Arc Belt-Frontenac-Adirondack Belt prior to ca. $1090 \mathrm{Ma}$ (Carr et al. 2000). This is evidenced by stitching plutons of the Frontenac intrusive suite, which span both the Frontenac terrane and Sharbot Lake domain, and are dated at ca. 1150-1175 Ma (Carr et al. 2000; Corfu and Easton 1997; McLelland et al. 1996). A possible alternative to the active subduction model is mantle enrichment and metasomatism of the underlying asthenosphere during subduction prior to the Shawinigan orogeny. Epsilon $\mathrm{Nd}(\sim+1-$ +4.5), initial $\operatorname{Sr}(\sim 0.700-0.703)$, and $T_{d m}$ values $(\sim 1200-1300)$ from the plutons of this study suggest derivation of the melt(s) from a relatively depleted source with minor involvement from ca. 1500-1200 Ma crust.

\subsubsection{Melt origin - Geochemistry}

Geochemical discrimination in felsic plutonic rocks is complicated and not always accurate. From formation of the melt to crystallisation, many processes can influence the melt and melt interaction with the surrounding rock. As a result, trace elements, 
which are often compatible in accessory phases such as zircon, apatite, allanite and monazite may fractionate or be assimilated from the continental crust, thus skewing the typical classification schemes (Frost and Frost 2013b). However, when used in conjunction with major element discrimination, trace elements can be a powerful tool.

Frost et al. (2001); Frost and Frost (2013a; 2013b) studied granitoids in terms of the varying concentrations of the major oxides, namely iron, aluminum and alkali contents, in conjunction with the trace element geochemistry. Using these elemental concentrations, the granitoids were categorised based on their melt geneses. The Kensington-Skootamatta plutons of this study are magnesian to ferroan, metaluminous to weakly peraluminous and alkalic to alkali-calcic. As their geochemistry is not consistent with each other, the Kensington-Skootamatta suite intrusions do not collectively relate to any one of the categories outlined by Frost and Frost (2013a). The geochemistry of the granite-monzogranite plutons is most consistent with that of calcalkalic ferroan leucogranites, which are interpreted to have been derived through partial melting of quartzofeldspathic crust (Frost and Frost 2013a). In contrast, the geochemistry of the syenite-monzonite plutons is most consistent with that of ferroan alkaline granitoids, which are interpreted to have been derived through fractionation of alkaline basalt with some partial melting of granitic crust (Frost and Frost 2013b).

Similarly to the Frost et al. (2001); Frost and Frost (2013a; 2013b) classification schemes, there are ambiguities in determining the tectonic setting of the KensingtonSkootamatta plutons using only trace element geochemistry. Using the Eby (1992) Atype discrimination diagram (figure 3.4c), the Westport area plutons represent mantle differentiates derived from sources similar to oceanic-island basalts emplaced in 
continental rifts. In contrast, according to the Eby (1992) discrimination diagram the Skootamatta and the granite-monzogranite plutons have chemistry consistent with derivation from continental crust or underplated crust that has been incorporated into an orogeny during accretionary events.

$\mathrm{U}$ and Th concentrations show a similar trend to the isotopic data (Cutts, Chapter 3). In the syenite-monzonite plutons the concentrations of $U$ and Th are low (1-3 ppm and 3-17 ppm respectively); $U$ and Th are elements that are typically associated with continental crust (Faure and Mensing 2005), and low values are consistent with an interpretation of minimal crustal contamination. This is consistent with data from other syenite-monzonite Kensington-Skootmatta plutons outside the study area that have regional gamma-ray signatures indicating low $U$ and Th (Easton 2008). In contrast, the more elevated levels of $U(2-6 \mathrm{ppm})$ and Th (5 -58 ppm) in the Leggat Lake and McLean plutons, and the still more elevated levels in the Barber's Lake pluton (U 590ppm, Th 25- >110 ppm), are consistent with an interpretation involving some contribution to the melt of a partial-melt derived from a granitic source (Faure and Mensing 2005).

Certain trace element ratios can also indicate the degree of crustal involvement in a melt. Mantle derived melts typically have $\mathrm{Nb} / \mathrm{Ta}$ values of $17.5 \pm 2$, whereas, typical continental crust is $\sim 11-12$ (Mohammed and Hassen 2012 and references therein). The Kensington-Skootamatta plutons in this study have $\mathrm{Nb} / \mathrm{Ta}$ ratios that range from 14-17, with the exception of Barbers Lake ( 9.4). Th/Ta ratios of $\sim 2$ are typical of the mantle, whereas the lower crust typically has values of $\sim 7.9$ and the upper crust 6.9 (Mohammed and Hassen 2012 and references therein). The Westport area plutons 
have tightly clustered values of 2.2-2.8. In contrast, the remaining plutons, in contrast, have values ranging from 8.4-24; significantly more enriched than typical crustal values.

Most of the Kensington-Skootamatta plutons have depletions in $\mathrm{Sr}, \mathrm{P}, \mathrm{Ti}$, and minor $\mathrm{Nb}$ anomalies (figure 3.3a,e) in conjunction with negative Eu anomalies in the REE profiles (figure 3.3b,f). This may have resulted from fractionation of plagioclase, apatite and possibly titanite. Furthermore, the HREEs are relatively enriched, indicating that they were not retained in the source. The Skootamatta pluton, (and parts of Rideau Lake and Foley Mountain plutons), have only slightly negative $\mathrm{P}, \mathrm{Ti}$ and $\mathrm{Nb}$ anomalies, and do not have a Sr anomaly (figure 3.3a,e) nor a Eu anomaly in their REE profiles (figure 3.3e). This suggests that apatite and titanite may have been minor fractionating phases, but not plagioclase. Furthermore, the Skootamatta intrusion is relatively depleted in HREE compared to the other Kensington-Skootamatta plutons, perhaps indicating a garnet-rich source that retained HREEs (figure 3.3f).

The trace-element depletions are more prominent in the granite-monzogranite plutons than the syenite-monzonite plutons. This implies that the quartzofeldspathic crust, from which the granite-monzogranite plutons were derived, was more depleted than the alkaline basalt, from which the syenite-monzonite plutons were derived. Furthermore, as the granite-monzogranite plutons in general have a depleted isotopic signature, this may reflect derivation from a juvenile quartzofeldspathic crust.

\subsubsection{Geochemistry and geochronology interpretations summary}

Using the petrography, geochemistry and geochronology studies of the Kensington-Skootamatta suite plutons, it is possible to subdivide them into four principal groups. 
1. The ca. 1086 Ma Skootamatta syenite is the oldest pluton studied and is the most varied in terms of rock-type and geochemistry. Remnant arc-signatures are more prevalent relative to the other plutons. The pluton was possibly derived from melting of host arc-volcanic and -plutonic rocks in the Grimsthorpe domain.

2. The ca. 1076-1072 Ma Westport area plutons have very similar ages of emplacement; the Wolfe Lake and Foley Mountain plutons have crystallization ages that are within error of each other and Rideau Lake is 1.1 Ma younger. Furthermore, the geochemistry that is consistent with derivation from a depleted alkaline basalt and emplacement in an intra-plate setting with some interaction with the host marbles in the Frontenac terrane, as previously noted by Marcantonio et al. (1990).

3. The ca. $1077 \mathrm{Ma}$ Leggat Lake and ca. $1070 \mathrm{Ma}$ McLean plutons in the Sharbot Lake domain are in close proximity to one another and have similar geochemistry that is consistent with derivation by partial melting of juvenile quartzofeldspathic crust. They have a similarly depleted isotopic character.

4. The ca. 1066 Ma Barber's Lake intrusion is broadly similar to the Leggat Lake and McLean plutons. Key differences are that it is ca. 3-10 Ma younger, and has a geochemical signature consistent with derivation by partial melting of juvenile quartzofelspathic crust that involved a greater amount of crustal contamination than any of the other plutons of the in this study.

\subsection{Tectonic model}

At the time of emplacement of the Kensington-Skootamatta suite ca. 1090-1060 $\mathrm{Ma}$, the terrane and domains that hosted the plutons were at varying crustal levels and composed of different rock-types (table 1.1, figure 2.1; figure 5.1). 
The Skootamatta syenite intruded into the Grimsthorpe domain rocks at ca. 1086 Ma. The country rocks include mafic metavolcanic rocks that had originated in a primitive-arc setting as well as Elzevirian plutonic rocks. At the time of emplacement of the syenite, the Grimsthorpe domain host rocks are interpreted to have been at $<12 \mathrm{~km}$ depth in the superstructure (figure 5.1). The Barber's Lake, Leggat Lake and McLean plutons intruded at ca. 1077-1066 Ma into marbles, mafic and felsic meta-plutonic and metavolcanic rocks of the Sharbot Lake domain at 20-12 km depth (figure 5.1). The Westport Area plutons intruded at ca. 1072-1076 Ma into marbles, orthogneisses and gabbro of the Frontenac terrane at 8-10 km depth (figure 5.1). The Mazinaw terrane, in contrast, is devoid of Kensington-Skootamatta plutons, is currently located geographically between the Grimsthorpe and Sharbot Lake domains and was at $>25 \mathrm{~km}$ depth at ca. $1060 \mathrm{Ma}$.

The Leggat Lake and McLean plutons, Barber's Lake, Skootamatta and Westport area plutons have similar geochemical signatures; however, in detail they can be distinguished on the basis of geochemistry and geochronology. Furthermore they were all emplaced over about 20 million years (ca. 1088-1066 Ma) into different domains and terranes which were at different crustal levels and were composed of varying rocktypes. It is therefore proposed that the pluton(s) in each of the subdivisions of the suite highlighted in section 5.2.3, had a distinct melt that was derived from the re-melting of rock within each respective terrane or domain (figure 5.1). The Kensington-Skootamatta suite is regionally extensive in the Grenville Province of Ontario and Québec and the emplacement ages are generally consistent. It is therefore possible that this is the case with all of the Kensington-Skootamatta suite plutons. 
Given that the age range of the plutons overlaps with the time of orogenesis, it is likely that they all may have resulted from a similar catalyst to cause widespread melting. Crustal delamination may have provided the heat necessary to cause this melting along with insulation of the overthickened crust to cause anatectic melting at mid-crustal levels. The latter is evidenced by ca. 1080-1060 Ma migmatite formation and granulite-facies metamorphism (Timmermann et al. 2002) in the Central Gneiss Belt; which was located in the orogenic infrastructure (figure 2.1).

Additionally, the oldest pluton from the Kensington-Skootamatta suite is the same age as stage 4 of the Midcontinent Rift (MCR) magmatic system (ca. $1086 \mathrm{Ma}$ ). Although centred in the Lake Superior region; $1000 \mathrm{~km}$ from Composite Arc BeltFrontenac-Adirondack Belt, the Midcontinent Rift may have heated the crust sufficiently to facilitate the ascent of plutons and facilitate melting (figure 5.1). This was similarly suggested by McLelland et al. (2001) for the generation of the 1100-1090 Ma Hawkeye granite suite in the Adirondack Highlands. This would also explain the lack of any timelag between the waning stages of the MCR magmatism and the beginning of the Kensington-Skootamatta suite magmatism. See figure 5.1 for a summary diagram for the emplacement of the Kensington-Skootamatta plutons in this study.

\subsubsection{Apparent absence of Kensington-Skootamatta plutonism in the Mazinaw terrane?}

The question as to why the Mazinaw terrane remains devoid of the KensingtonSkootamatta suite plutons remains unclear. Perhaps the temperature and pressure conditions and the deformational stresses in the infrastructure of the orogeny were unsuitable to the ponding of plutons. This conclusion is evidenced by ca. $1090-1050$ 
deformation and metamorphism in the northernmost segment of the Mazinaw terrane and the ca. 1080 Ma pegmatite intrusion. Alternatively, perhaps the Mazinaw terrane was not geographically proximal to the other constituent terranes and domains of the superstructure ca. 1090-1060 Ma, thus melting was not initiated.

\subsection{The Cranberry Lake pluton}

The Cranberry Lake pluton has a crystallization age of 1157.2 $\pm 1.4 \mathrm{Ma}$. This age is consistent with the emplacement of the Frontenac intrusive suite. Furthermore, the Cranberry Lake pluton has similar geochemistry to the Frontenac intrusive suite plutons (See section 3.2.4). The Cranberry Lake pluton is, therefore, interpreted to be part of the Frontenac intrusive suite.

The trace element geochemistry of the Cranberry Lake granite indicates a mixture of tectonic environments; volcanic arc, within-plate, orogenic, and A-type (figure 3.4a, b). Trace element ratios suggest derivation from a mantle melt with contamination from an upper crustal source $(\mathrm{Nb} / \mathrm{Ta}=13.8-14.1 ; \mathrm{Th} / \mathrm{Ta}=6.75-9.99)$ which is consistent with plotting in the A2 field in the Eby (1992) discrimination scheme (continental crust and/or underplated crust influenced by continental collision). The depletions in $\mathrm{Nb}, \mathrm{Ti}, \mathrm{Sr}$ and $\mathrm{P}$ on the extended mantle-normalised multi-element plots and depletion in Eu on the chondrite-normalised REE plot suggest fractionation of plagioclase, apatite and possibly titanite.

\subsubsection{Implications for the Robertson Lake Shear Zone}

The Robertson Lake shear zone is interpreted as a crustal-scale extensional fault active most recently ca. 1030-940 Ma (Busch et al. 1997; Carr et al. 2000). It has also been suggested that the shear zone may have been active at an earlier time during 
crustal shortening. The ca. 1160 Ma Cranberry Lake pluton appears to have been injected or intruded concordantly into the Robertson Lake shear zone. The crystallisation age of the Cranberry Lake pluton may provide insight into a possible earlier period of compressional activity along the Robertson Lake shear zone that has been alluded to in previous studies (Busch et al. 1997).

\subsection{The Elphin pluton}

The Elphin pluton has a crystallization age of $1178.4+2.5 /-2.3 \mathrm{Ma}$, which is consistent with the emplacement of the Frontenac intrusive suite. The Elphin pluton, is therefore, interpreted to be part of the Frontenac intrusive suite.

The Elphin pluton is heterogeneous, ranging from syenite to granite in composition. The major element geochemistry of the Elphin intrusion is consequently varied, ranging from calc-alkalic to shoshonitic, strongly metaluminous to peraluminous, and strongly ferroan to strongly magnesian (figure 3.2). Using the Frost and Frost (2013) classification scheme for leucogranites, this corresponds to the chemistry of Cordilleran intrusions that were derived through extreme differentiation of cold, wet, oxidising magma. The trace-element tectonic discrimination diagrams (figure 3.4) and primitive mantle-normalised multi-element plots (figure 3.3d) similarly indicate that the Elphin pluton has a volcanic arc affinity (strong $\mathrm{Nb}$ depletion). The small negative $\mathrm{P}$ and Ti anomalies in the mantle-normalised multi-element plots may have resulted from minor fractionation of apatite and titanite. The steep (HREE depleted) chondritenormalised REE profile (figure 3.3h) with no Eu anomaly indicates that the Elphin intrusion could have had a garnet-rich source that withheld the HREEs and likely did not fractionate plagioclase. Trace element ratios give mixed results. Nb/Ta 13.8-14.1 lie 
between mantle and continental crust values and Th/Ta 6.75-9.99 are typical of lower to upper crustal values. Isotopic values $(\varepsilon N d-1.11$ to +4.48$)$ range from slightly contaminated by continental crust to depleted mantle.

The Elphin pluton intruded into the ca. 1224 Ma Lavant gabbro; an arc-affinity intrusive complex cut by monzogranite intrusive bodies (Corfu and Easton 1997). The geochemical character of the Elphin pluton is very similar to that of the Lavant gabbro. It is therefore possible that the Elphin pluton derived some of its geochemical signature from the Lavant gabbro which may also have been a potential source for the ca. 1226 Ma inheritance observed in the geochronology results.

Wu and Kerrich (1986) hypothesised that their major and trace element geochemistry and high ${ }^{18} \mathrm{O}$ data for the Elphin pluton may suggest partial melting from an ${ }^{18} \mathrm{O}$ enriched metadiorite-metagabbro precursor. This precursor was postulated to have been subjected to open-system enrichment with the high ${ }^{18} \mathrm{O}$ carbonate country rock. It has been interpreted herein that the Elphin pluton may have had some degree of interaction with the Lavant gabbro complex. This provides further credence to the conclusions made by Wu and Kerrich (1986).

\subsection{Implications for the Frontenac intrusive suite}

Frontenac intrusive suite plutons are dominantly found in east-central Sharbot Lake domain and throughout the Frontenac terrane. The Cranberry Lake and Elphin plutons are located along the western margin of the Sharbot Lake domain, and extend Shawinigan magmatism further westward into Sharbot Lake domain.

Lumbers et al. (1990) and Davidson and van Breemen (2000a) noted that the Kensington-Skootamatta and Frontenac intrusive suites have similar rock-type and 
geochemistry. This conclusion was based only on the syenite-monzonite plutons. The Elphin and Cranberry Lake plutons were originally thought to be part of the KensingtonSkootamatta suite on the basis of their similar petrography and geochemistry to both the syenite-monzonite and the granite-monzogranite plutons. It is thus shown that the granites also, have similar petrography and geochemistry to the Frontenac intrusive suite. 


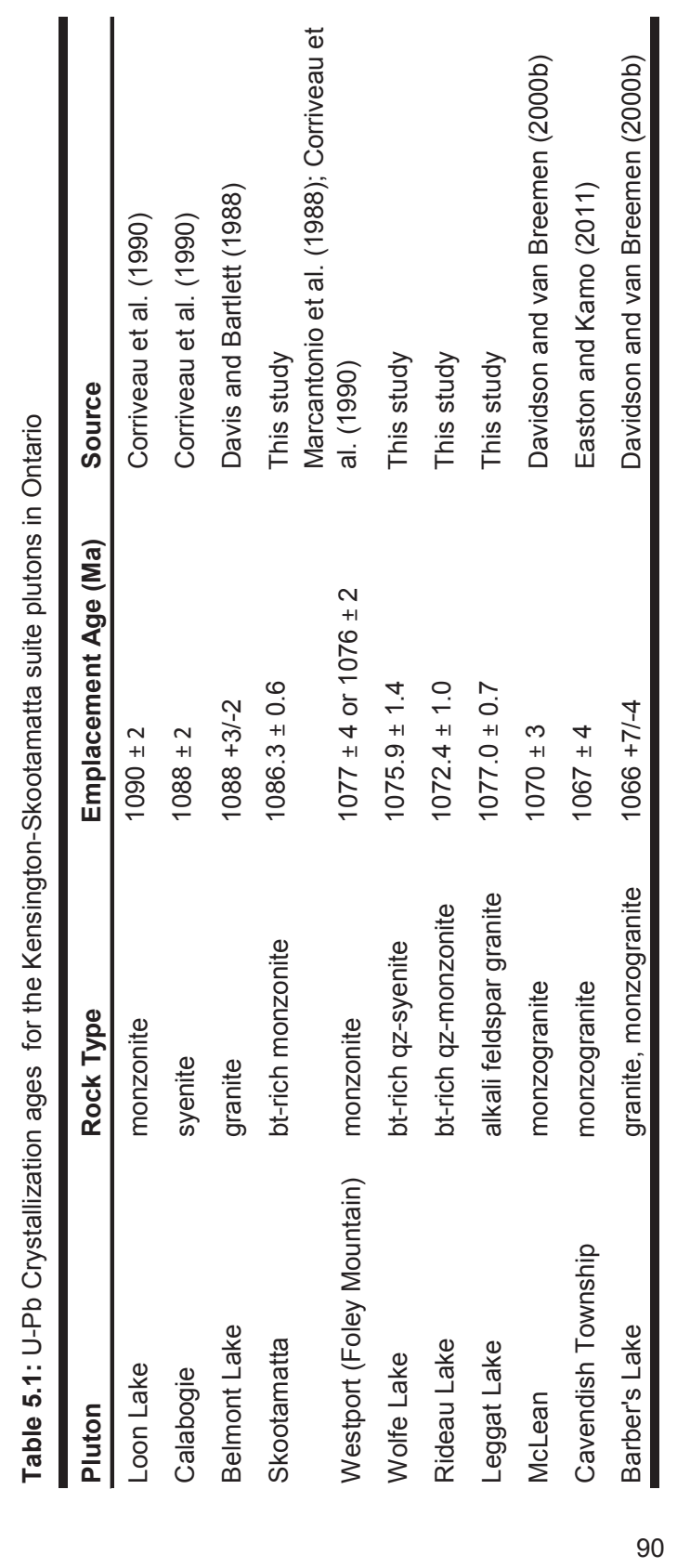




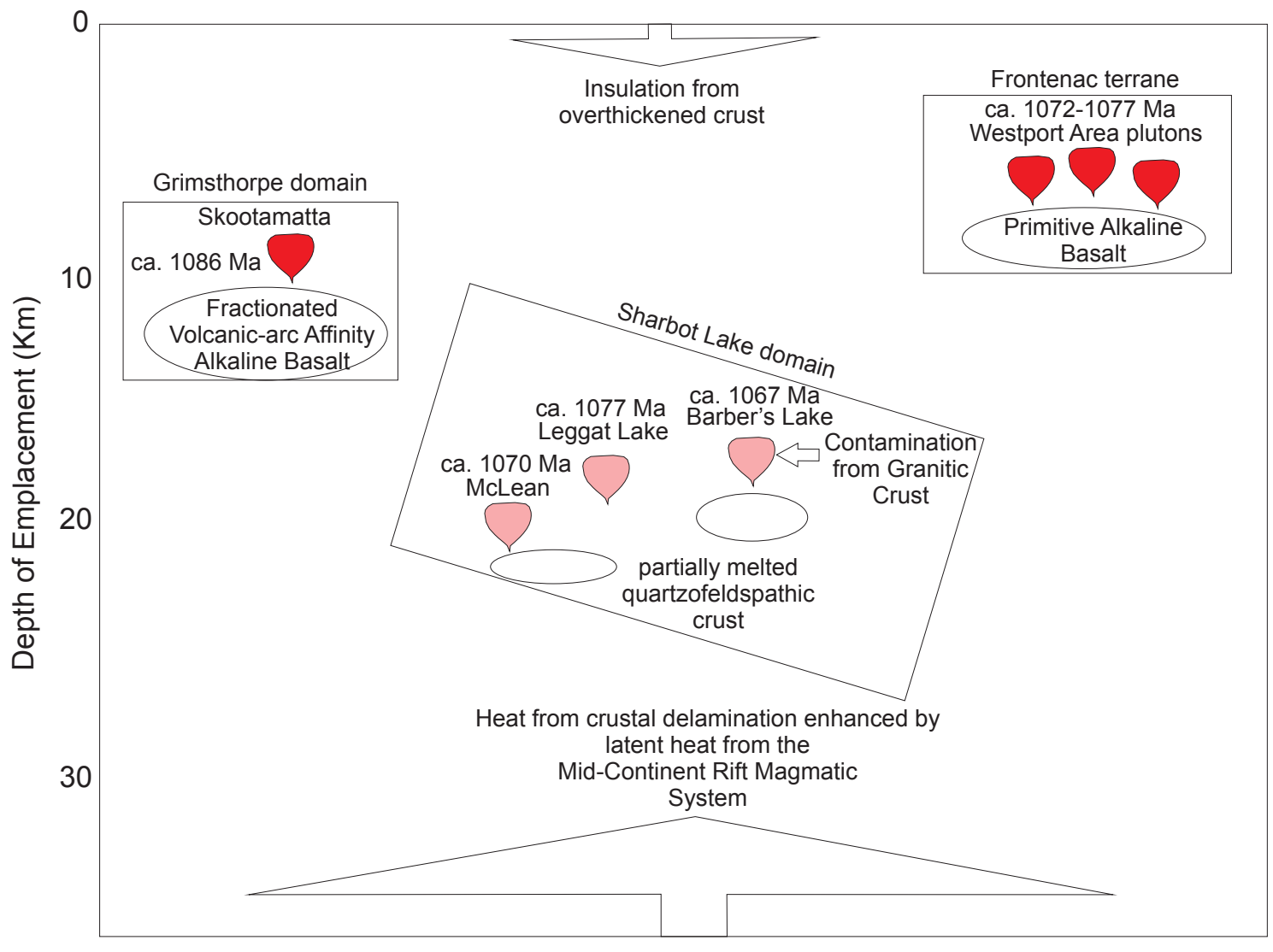

Figure 5.1: Schematic summary diagram for the ca. 1086-1067 Ma emplacement of the plutons of this study. Syenite-monzonite plutons are shown in red, whereas the granite-monzogranite plutons are shown in pink. The depth of emplacement refers only to the depth of the host terranes and domains (rectangles) when the plutons were emplaced, not the depth at which the original melts were generated (ovals). The arrows represent the heat sources that have been interpreted to have generated the melts. 


\section{Chapter 6 - Conclusions}

The plutons of the Kensington-Skottamatta suite are tectonically important in the Grenville Province as they were emplaced ca. 1090-1060 Ma, across multiple lithotectonic terranes and domains, which were at different crustal levels within the orogenic superstructure of a Himalayan-scale orogeny. The Kensington-Skootamatta suite provides the only body of evidence of magmatism in the Composite Arc Belt and Frontenac terrane during this time. When this project was initiated, the nine plutons studied were all thought to have been part of the Kensington-Skootamatta suite (Corriveau et al. 1990; Easton 1992; Easton 2001; Easton 2008). It was further proposed by Easton (2008) that the Kensington-Skootamatta suite was composed of two suites; an early ca. 1080-1070 Ma syenite-monzonite suite and a later ca. 10701060 Ma granite-monzogranite suite.

\subsection{First order conclusions}

1. The Skootamatta, Westport area, Barber's Lake, Elphin, McLean, and Leggat Lake plutons have a roughly round shape and they are not deformed, nor metamorphosed (section 3.2).

2. The Cranberry Lake pluton has an irregular map pattern, and has a strong foliation; however, it appears to be unmetamorphosed.

3. The Skootamatta and Westport area plutons have a syenite-monzonite rock-type, whereas the Barber's Lake, Elphin, McLean, Leggat Lake and Cranberry Lake plutons have a granite-monzongranite rock-type.

4. The syenite-monzonite plutons have lower $\mathrm{SiO}_{2}$ and higher alkali content, are more alkalic, dominantly metaluminous, and ferroan to magnesian than the granite- 
monzogranite plutons. The granite-monzogranite plutons, in contrast, are metaluminous to peraluminous and dominantly ferroan.

5. The granite-monzogranite plutons have more pronounced trace element anomalies than the syenite-monzonite plutons.

6. The Skootamatta and Elphin plutons have steeper multi-element profiles that are more HREE depleted than the other plutons and the Barber's Lake pluton has greater depletions in $\mathrm{Ba}$, and greater enrichments in $\mathrm{U}$, Th, and $\mathrm{Pb}$ than the other plutons.

7. The Skootamatta and Elphin pluton dominantly have trace-element signatures consistent with that of volcanic arc granites, whereas the other plutons plot as withinplate/A-type to anomalous ocean ridge granites.

8. Of the syenite-monzonite plutons that were dated in this study, the Skootamatta pluton has a crystallization age of $1086.3 \pm 0.6 \mathrm{Ma}$; the Rideau Lake pluton has a crystallization age of $1072 . \pm 1.0 \mathrm{Ma}$, and the Wolfe Lake pluton has a crystallization age of $1075.9 \pm 1.4 \mathrm{Ma}$. Of the granite-monzogranite plutons that were dated in this study, the Leggat Lake pluton has a crystallization age of $1077.0 \pm 0.7 \mathrm{Ma}$.

9. The crystallization ages of the Elphin and Cranberry Lake plutons were determined to be $1178.4+2.5 /-2.3 \mathrm{Ma}$ and $1157.2 \pm 1.4 \mathrm{Ma}$, respectively.

\subsection{Second order conclusions}

1. On the basis of age, the Skootamatta, Westport Area, Leggat Lake, McLean and Barber's Lake intrusions are part of Kensington-Skootamatta suite.

2. On the basis of geochemistry and age, the Cranberry Lake pluton is part of the Frontenac intrusive suite. 
3. On the basis of age, the Elphin pluton is part of the Frontenac intrusive suite and has inherited age and geochemical characteristics from the Lavant gabbro.

4. This study confirms the suggestion of Easton (2008) that the KensingtonSkootamatta suite consists of both syenite-monzonite and granite-monzogranite intrusions that can be distinguished petrographically and geochemically. The Skootamatta, and Westport Area plutons are part of an early 1086-1072 Ma syenitemonzonite suite, and the Leggat Lake, McLean and Barber's Lake plutons are part of a later 1077-1066 Ma granite-monzogranite suite.

5. The geochemistry of the Kensington-Skootamatta plutons do not consistently indicate a particular tectonic setting or melt origin. They range from a volcanic arc to within-plate to A-type tectonic setting, and have depleted isotopic signatures and geochemistry indicative of melts that originated from an alkaline basalt or juvenile quartzofeldspathic crust.

6. The granite-monzogranite plutons show more evidence of involvement from continental crust than the syenite-monzonite plutons.

7. There are differences in the host-terranes and-domains that could account for the differences observed between the plutons: i) The geochemical signature of the Skootamatta pluton was possibly derived from the host volcanic-arc rocks of the Grimsthorpe domain; ii) The granite-monzogranite plutons in the Sharbot Lake domain may have been sourced from juvenile quartzofeldspathic crust and later contaminated by granitic crust; iii) The Westport area plutons may have been sourced from alkaline basalt with later interaction with the host marbles in the Frontenac terrane. 
8. Due to their emplacement over 20 million years, at varying crustal levels, across different domains/terranes within the orogenic superstructure, each pluton in the Kensington-Skootamatta suite had a discrete source melt.

9. A possible catalyst to initiate coeval melting for all of the plutons may include crustal delamination, insulation due to crustal overthickening, and the waning Mid-Continent Rift magmatic system. This is consistent with current tectonic models for Grenville orogenesis.

10. The Mazinaw terrane is devoid of Kensington-Skootamatta plutons. This may be due to the pressure and temperature conditions and deformation stresses at that crustal level at ca. $1060 \mathrm{Ma}$.

\section{Future Work}

Future work on the Kensington-Skootamatta plutons may include studies on Ar-Ar thermochronology on mica and hornblende within the plutons and comparison of this data with their crystallisation ages to determine their crustal level during emplacement. Further study of the granite-monzogranite plutons of this age in the Composite Arc Belt is required to determine whether the age, rock-type and geochemistry results from this study are as widespread as the characteristics from the syenite-monzonite plutons.

The Elphin pluton has a much more complex geochemistry than previously thought and mapping could help to establish the heterogeneities in rock-type in relation to the geochemistry. As was alluded to in Chapter 4, the age of emplacement of the Cranberry Lake pluton may indicate an earlier period of activation than previously thought for the Robertson Lake shear zone. Detailed mapping and structural analysis of 
the pluton and its relationship to the shear zone could help to prove or disprove this hypothesis. 


\section{REFERENCES}

Barbarin, B., 1990. Granitoids: main petrogenetic classifications in relation to origin and tectonic setting. Geological Journal, 25: 227-238.

Beaumont, C., Nguyen, M.H., Jamieson, R.A. and Ellis, S., 2006. Crustal flow modes in large hot orogens. In: R.D. Law, M.P. Searle and L. Godin (Editors), Channel flow, ductile extrusion, and exhumation of lower-mid crust in continental collision zones. Geological Society of London Special Publication 268: 91-145.

Bonin, B., Azzouni-Sekkal, A., Bussy, F. and Ferrag, S., 1998. Alkali-calcic and alkaline post-orogenic (PO) granite magmatism: petrologic constraints and geodynamic settings. Lithos, 45: 45-70.

Bowring, J., 2012. Tripoli, Cyber Infrastructure Research \& Development Lab for the Earth Sciences. College of Charleston - Department of Computer Science, Charleston, South Carolina.

Bowring, J., 2013. U-Pb Redux, Cyber Infrastructure Research \& Development Lab for the Earth Sciences. College of Charleston - Department of Computer Science, Charleston, South Carolina.

Busch, J.P., Mezger, K. and van der Pluijm, B.A., 1997. Suturing and extensional reactivation in the Grenville orogen, Canada. Geology, 25(6): 507-510.

Busch, J.P. and van der Pluijm, B.A., 1995. Late orogenic, plastic to brittle extension along the Robertson Lake shear zone: Implications for the style of deep-orogenic extension in the Grenville orogen, Canada. Precambrian Research, 77: 83-100.

Busch, J.P., van der Pluijm, B.A., Hall, C.M. and Essene, E.J., 1996. Listric normal faulting during postorogenic extension revealed by $40 \mathrm{Ar} / 39 \mathrm{Ar}$ thermochronology near the Robertson Lake shear zone, Grenville orogen, Canada. Tectonics, 15(2): 387-402.

Carr, S.D., Easton, R.M., Jamieson, R.A. and Culshaw, N.G., 2000. Geologic transect across the Grenville orogen of Ontario and New York. Canadian Journal of Earth Sciences, 37: 193-216.

Chiarenzelli, J.R., Hudson, M.R., Dahl, P.S. and deLorraine, W.D., 2013. Constraints on deposition in the Trans-Adirondack Basin, Northern New York: Composition and origin of the Popple Hill Gneiss. Precambrian Research, 214-215: 154-171.

Corfu, F. and Easton, R.M., 1995. U-Pb geochronology of the Mazinaw terrane, an imbricate segment of the Central Metasedimentary Belt, Grenville Province, Ontario. Canadian Journal of Earth Sciences, 32: 959-976.

Corfu, F. and Easton, R.M., 1997. Sharbot Lake terrane and its relationships to Frontenac terrane, Central Metasedimentary Belt, Grenville Province: new insights from U-Pb geochronology. Canadian Journal of Earth Sciences, 34: 1939-1257.

Corfu, F., Hanchar, J.M., Hoskin, P.W.O. and Kinny, P., 2003. Atlas of Zircon Textures. In: J.M. Hanchar and P.W.O. Hoskin (Editors), Zircon. Reviews in Mineralogy and Geochemistry. 469-500 
Corrigan, D. and Hanmer, S., 1997. Anorthosites and related granitoids in the Grenville orogen: A product of convective thinning of the lithosphere. Geology, 25: 61-64.

Corriveau, L., 1990. Proterozoic subduction and terrane amalgamation in the southwestern Grenville province, Canada: Evidence from ultrapotassic to shoshonitic plutonism. Geology, 15: 615-617.

Corriveau, L. and Gorton, M.P., 1993. Coexisting K-rich alkaline and shoshonitic magmatism of arc affinities in the Proterozoic: a reassessment of syenitic stocks in the southwestern Grenville Province. Contributions to Minerology and Petrology, 113: 262-279.

Corriveau, L. and Morin, D., 2000. Modelling 3D architecture of western Grenville from surface geology, xenoliths, styles of magma emplacement, and Lithoprobe reflectors. Canadian Journal of Earth Sciences, 37: 235-251.

Corriveau, L., Heaman, L.M., Marcantonio, F. and van Breemen, O., 1990. 1.1 Ga K-rich alkaline plutonism in the SW Grenville Province. Contributions to Mineralogy and Petrology, 105: 473-485.

Corriveau, L., Morin, D., Tellier, M., Amelin, Y. and van Breemen, O., 1996a. Insights on minette emplacement and the lithosphere underlying the southwest Grenville Province of Quebec at 1,08 Ga. Geological Survey of Canada Open File, 3228: 139-142.

Corriveau, L., Tellier, M.L. and Morin, D., 1996b. Le dyke de minette de Rivard et le complexe gneissique cuprifère de Bondy; implications tectonique et métallogénique pour la région de Mont-Laurier, Province de Grenville, Québec. Commission géologique du Canada, Dossier public, 3078.70p

Cosca, M.A., Essene, E.J., Kunk, M.J. and J.F., S., 1992. Differential unroofing within the Central Metasedimentary Belt of the Grenville Orogen: constraints from 40Ar/39Ar thermochronology. Contributions to Mineralogy and Petrology, 110: 211-225.

Cousens, B.L., 1996. Magmatic evolution of Quaternary mafic magmas at Long Valley Caldera and hte Devils Postpile, California: Effects of crustal contamination on lithospheric mantle-derived magmas. Journal of Geophysical Research, 101(B12): 27673-27689.

Cox, K.G., Bell, J.D. and Pankhurst, R.J., 1979. The Interpretation of Igneous Rocks. George Allen \& Unwin. 450p

Culshaw, N. and Dostal, J., 1997. Sand Bay gneiss association, Grenville Province, Ontario: a Grenvillian rift (and -drift) assemblage stranded in the Central Gneiss Belt. Precambrian Research, 85: 97-113.

Culshaw, N.G., Jamieson, R.A., Ketchum, J.W.F., Wodicka, N., Corrigan, D. and Reynolds, P.H., 1997. Transect across the northwestern Grenville orogen, Georgian Bay, Ontario: Polystage convergence and extension in the lower orogenic crust. Tectonics, 16(6): 966-982.

Culshaw, N., Beaumont, C. and Jamieson, R.A., 2006. The orogenic suprastructure -infrastructure concept: Revised, quantified, and revived. Geology, 34: 733-736. 
Cureton, J.S., van der Pluijm, B.A. and Essene, E.J., 1997. Nature of the ElzevirMazinaw domain boundary, Grenville Orogen, Ontario. Canadian Journal of Earth Sciences, 34: 976-991.

Cutts, J., Carr, S.D. and Easton, R.M. 2011. Characterization of syntectonic to posttectonic intrusions of circa 1090 to $1065 \mathrm{Ma}$ age in the southeastern Central Metasedimentary Belt, Grenville Province; in Summary of Field Work and Other Activities, 2011, Ontario Geological Survey, Open File Report 6270, p.6-1 to 6-7.

Cutts, J., Easton, R.M., and Carr, S.D. 2012. Major, Trace element, and isotope geochemistry of plutons intruded circa 1090 to $1065 \mathrm{Ma}$ in the southeastern Central Metasedimentary Belt, Grenville Province; in Summary of Field Work and Other Activities, 2012, Ontario Geological Survey, Open File Report 6280, p.15-1 to 15-5.

Cutts, J., Easton, R.M. and Carr, S.D. 2013. Circa 1060-1090 Ma syn- to postorogenic plutonism in the Grenville Province of Ontario: Insights from major, trace element and isotope geochemistry; Geological Association of Canada-Mineralogical Association of Canada, Winnipeg'13, Program with Abstracts, v.36, p.83-84.

Davidson, A., 2001. Evidence for and significance of high-level plutonism in the southeastern composite arc belt, Grenville Province, Ontario. In Geological Association of Canada - Mineralogical Association of Canada annual meeting, St. John's, NL, Abstract Vol 26, p. A34.

Davidson, A. and van Breemen, O., 2000a. Age and extent of the Frontenac plutonic suite in the Central metasedimentary belt, Grenville Province, southeastern Ontario. Geological Survey of Canada Current Research, 2000-F4: 1-17.

Davidson, A. and van Breemen, O., 2000b. Late Grenvillian granite plutons in the Central metasedimentary belt, Grenville Province, southeastern Ontario. Geological Survey of Canada Current Research, 2000-F5: 1-11.

Davidson, A. and van Breemen, O., 2000c. Geology of the Mountain Grove pluton, Central Metasedimentary Belt, Grenville Province, Ontario. Current Research, 2000-C23: 1-7.

Davis, D.W. and Bartlett, J.R., 1988. Geochronology of the Belmont Lake Metavolcanic Complex and implications for crustal development in the Central metaseinentary Belt, Grenville Province, Ontario. Canadian Journal of Earth Sciences, 25: 1751-1759.

Easton, R.M., 1986. Geochronology of the Grenville Province. In: J.M. Moore, A. Davidson and A.J. Baer (Editors), The Grenville Province. Special Paper Geological Association of Canada, v.31: p. 127-173.

Easton, R.M., 1992. The Grenville Province and the Proterozoic History of Central and Southern Ontario. In: P.C. Thurston, H.R. Williams, R.H. Sutcliffe and G.M. Stott (Editors), Geology of Ontario. Ontario Geological Survey, Special Volume 4, part 2, p. 713-904. 
Easton, R.M., 2001a. Geology and Mineral Potential of the Puzzle Lake Area, Central Metasedimentary Belt, Grenville Province. Ontario Geological Survey, Open File Report 6064: 26p.

Easton, R.M., 2001b. Precambrian geology, Mazinaw Lake area. Ontario Geological Survey, Preliminary Map P3439, 1:50 000 scale.

Easton, R.M., 2001c. Precambrian Geology, Sharbot Lake area. Ontario Geological Surve, Preliminary Map P3440, 1:50 000 scale..

Easton, R.M., 2001d. Precambrian geology, Tichborne area. Ontario Geological Survey, Preliminary Map P3443, 1:50 000 scale..

Easton, R.M., 2008. Rossing-Style Uranium Potential of Late Granites and Pegmatites of the Central Metasedimentary Belt, Grenville Province. In Summary of Field Work and Other Activities 2008, Ontario Geological Survey, Open File Report 6226: 16.1-16.10.

Easton, R.M. and Ford, F.D., 1994. Geology of the Grimsthorpe Area, Hastings and Lennox and Addington Counties, Grenville Province. Ontario Geological Survey, Open File Report, 5894, 153p.

Easton, R.M. and Kamo, S.L., 2008. New U-Pb zircon ages reveal a long-lived magmatic history of the Harvey-Cardiff domain of the Composite Arc Belt of the Grenville Province in Ontario. Geological Society of America, Abstracts with Program, 40: p. 228.

Easton, R.M. and Kamo, S.L., 2011. Harvey-Cardiff domain and its relationship to the Composite Arc Belt, Grenville Province: insights from U-Pb geochronology and geochemistry. Canadian Journal of Earth Sciencs, 48: 347-370.

Eby, G.N., 1992. Chemical subdivision of the A-type granitoids: Petrogenetic and tectonic implications. Geology, 20: 641-644.

Faure, G. and Mensing, T.M., 2005. The U-Pb, Th- $\mathrm{Pb}$, and Pb-Pb Methods, Isotopes - Principles and Applications. 3rd ed. John Wiley \& Sons, Inc., Hoboken, NJ. 897p

Frost, C.D., and Frost, R.B. 2013b. Geochemical classification of high-silica granites (leucogranites), Geological Society of America, Abstracts with Program, 45(7), 389.

Frost, C.D. and Frost, R.B., 2013a. Proterozoic ferroan feldspathic magmatism. Precambrian Research, 228: 151-163.

Frost, B.R., Barnes, C.G., Collins, W.J., Arculus, R.J., Ellis, D.J. and Frost, C.D., 2001. A Geochemical Classification for Granitic Rocks. Journal of Petrology, 42(11): 2033-2048.

GeoLabs, 2009. Schedule of Fees and Services. Geoscience Laboratories, Sudbury.

Grammatikopoulos, T.A., Clark, A.H. and Archibald, D.A., 2007. Petrogenesis of the Leo Lake and Lyndhurst plutons, Frontenac terrane, Central Metasedimentary Belt, southeastern Ontario, Canada. Canadian Journal of Earth Sciencs, 44: 107-126.

Hewitt, D.F., 1964. Gananoque Area; Ontario Department of Mines, Map 2054; scale 1:126 640 . 
Hanchar, J.M. and Miller, C.F., 1993. Zircon zonation patterns as revealed by cathodoluminescence and backscattered electron images: Implications for interpretation of complex crustal histories. Chemical Geology, 110: 1-13.

Hanmer, S. and McEachern, S., 1992. Kinematical and rheological evolution of a crustal-scale ductile thrust zone, Central Metasedimentary Belt, Grenville orogen, Ontario. Canadian Journal of Earth Sciences, 29: 1779-1790.

Hanmer, S., Corrigan, D., Pehrsson, S. and Nadeau, L., 2000. SW Grenville Province, Canada: the case against post-1.4 Ga accretionary tectonics. Tectonophysics, 319: 33-51.

Kamo, S.L., Krogh, T.E. and Kumarapeli, P.S., 1995. Age of the Grenville dyke swarm, Ontario - Quebec: Implications for the timing of lapetan rifting. Canadian Journal of Earth Sciencs, 32: 273-280.

Krogh, T.E., 1982a. Improved accuracy of U-Pb zircon ages by the creation of more concordant systems using an air abrasion technique. Geochimica et Cosmochimica Acta, 46: 637-649.

Krogh, T.E., 1982b. Improved accuracy of U-Pb zircon dating by selection of more concordant fractions using a high gradient magnetic separation technique. Geochimica et Cosmochimica Acta, 46: 631-635.

Lumbers, S.B., Heaman, L.M., Vertolli, V.M. and Wu, T.-W., 1990. Nature and timing of Middle Proterozoic magmatism in the Central Metasedimentary Belt, Ontario, In Mid-Proterozoic Laurentia-Baltica. Geological Association of Canada, Special Paper 38, pp. 243-276.

Marcantonio, F., McNutt, R.H., Dickin, A.P. and Heaman, L.M., 1990. Isotopic evidence for the crustal evolution of the Frontenac Arch in the Grenville Province of Ontario, Canada. Chemical Geology, 83: 297-314.

Mattinson, J.M., 2005. Zircon U-Pb chemical abrasion ("CA-TIMS") method: Combined annealing and multi-step partial dissolution analysis for improved precision and accuracy of zircon ages. Chemical Geology, 220: 47-66.

McEachern, S. and van Breemen, O., 1993. Ages of deformation within the Central Metasedimentary Belt boundary thrust zone, southwest Grenville Orogen: Constraints on the collision of the mid-Proterozoic Elzevir terrane. Canadian Journal of Earth Sciences, 30: 1155-1165.

McLelland, J., Daly, J.S. and McLelland, J.M., 1996. The Grenville Orogenic Cycle (ca. 1350-1000 Ma); an Adirondack perspective. Tectonophysics, 265: 1-28.

McLelland, J.M., Hamilton, M., Selleck, B., McLelland, J., Walker, D. and Orrell, $\mathrm{S}$., 2001. Zircon U-Pb geochronology of the Ottawan Orogeny, Adirondack Highlands, New York: regional and tectonic implications. Precambrian Research, 109: 39-72.

Mohammed, E.-B. and Hassen, I.S., 2012. The late Ediacaran (580-590 Ma) onset of anorogenic alkaline magmatism in the Arabian-Nubian Shield; Katherina A-type rhyolites of Gabal Maèain, Sinai, Egypt. Precambrian Research, 216: 1-22.

Ontario Geological Survey 2011. 1:250 000 scale bedrock geology of Ontario. Ontario Geological Survey, Miscellaneous Release, Data 126-Revision 1. 
Parrish, R.R., Roddick, J.C., Loveridge, W.D. and Sullivan, R.W., 1987. Uraniumlead analytical techniques at the Geochronology Laboratory, In Radiogenic age and Isotopic Studies; Report 1; Geological Survey of Canada Paper 87-2: 3-7.

Pearce, J.A., Harris, N.B.W. and Tindle, A.G., 1984. Trace element discimination diagrams for the tectonic interpretation of granitic rocks. Journal of Petrology, 25: 956-983.

Peccerillo, A. and Taylor, S.R., 1976. Geochemistry of Eoxene calc-alkaline volcanic rocks from the Kastamonu area, northern Turkey. Contibutions to Mineralogy and Petrology, 25: 63-81.

Pehrsson, S., Hanmer, S., and van Breemen, O., 1996. U/Pb geochronology of the Raglan gabbro belt, central metasedimentary belt, Ontario: Implication for an ensialic marginal basin in the Grenville orogen. Canadian Journal of Earth Sciences, 33: 691-702

Pupin, J.P., 1980. Zircon and Granite Petrology. Contributions to Mineralogy and Petrology, 73: 207-220.

Rivers, T., 2008. Assembly and preservation of lower, mid, and upper orogenic crust in the Grenville Province - Implications for the evolution of large hot long-duration orogens. Precambrian Research, 167: 237-259.

Rivers, T., 2012. Upper-crustal orogenic lid and mid-crustal core complexes: signature of a collapsed orogenic plateau in the hinterland of the Grenville Province. Canadian Journal of Earth Sciencs, 49: 1-42.

Rollinson, H.R., 1993. Using geochemical data: Evaluation, presentation, interpretation. Longman Scientific \& Technical, Harlow, Essex, England. $352 p$

Sager-Kinsman, E.A. and Parrish, R.R., 1993. Geochronology of detrital zircons from the Elzevir and Frontenac terranes, Central Metaseimentary Belt, Grenville Province, Ontario. Canadian Journal of Earth Sciencs, 30: 465473.

Schoene, B. and Bowring, S.A., 2006. U-Pb systematics of the McLure Mountain syenite: thermochronological constraints on the Age of the 40Ar/40Ar standard MMhb. Contibutions to Mineralogy and Petrology, 151: 615-630.

Shand, S.J., 1943. Eruptive Rocks. Their Genesis, Composition, Classification and Their Relation to Ore Deposits with a Chapter on Meteorite. John Wiley \& Sons, New York. 444p

Shieh, Y., 1985. High-180 granitic plutons from the Frontenac Axis, Grenville Province of Ontario, Canada. Geochimica et Cosmochimica Acta, 49: 117123.

Stacey, J.S. and Kramers, J.D., 1975. Approximation of Terrestrial Lead Isotope Evolution by a 2-stage Model. Earth and Planetary Science Letters, 26: 207-221.

Sun, S.S. and McDonough, W.F., 1989. Chemical and isotopic systematics of oceanic basalts: implications for mantle composition and processes. In Geological Society Special Publication, 42: 313-345. 
Timmermann, H., Jamieson, R.A., Parrish, R.R. and Culshaw, N., 2002. Coeval migmatites and granulites, Muskoka domain, southwestern Grenville Province, Ontario. Canadian Journal of Earth Sciencs, 39: 239-258.

van Breemen, O., Peterson, T.D. and Sandeman, H.A., 2005. U-Pb zircon geochronology and $\mathrm{Nd}$ isotope geochemistry of the Proterozoic granitoids in the western Churchill Province: intrusive age pattern and Archean source domains Canadian Journal of Earth Sciencs, 42: 339-377.

Wallach, J., 1973. The metamorphism and structural geology of the Hinchinbrooke gneiss and its age relationship to metasedimentary and metavolcanic rocks of the Grenville Group; Unpublished PHd thesis, Queen's University, Kingston, Ontario, $141 \mathrm{pp}$.

Whalen, J.B., Currie, K.L. and Chappell, B.W., 1987a. A-type granites: geochemical characteristics, discrimination and petrogenesis. Contributions to Mineralogy and Petrology, 95: 407-419.

White, D.J., Forsyth, D.A., Asudeh, I., Carr, S.D., We, H., Easton, R.M. and Mereu, R.F., 2000. A seismic-based cross-section of the Grenville Orogen in southern Ontario and western Quebec. Canadian Journal of Earth Sciencs, 37: 183-192.

$\mathrm{Wu}, \mathrm{T}$. and Kerrich, R., 1986. Combined oxygen isotope - compositional studies of some granitoids from the Grenville Province of Ontario, Canada: implications for source regions. Canadian Journal of Earth Sciencs, 23: 1412-1432.

Wynne-Edwards, H.R., 1967. Westport-Area, Ontario, with special emphasis on the Precambrian rocks. Geological Survey of Canada Memoir, 346: 142p. 